\title{
Masters and Doctorate Theses Issued as Laboratory Reports
}

\author{
Elizabeth B. Howard
}

\section{OAK RIDGE NATIONAL LABORATORY}




\section{DISCLAIMER}

This report was prepared as an account of work sponsored by an agency of the United States Government. Neither the United States Government nor any agency Thereof, nor any of their employees, makes any warranty, express or implied, or assumes any legal liability or responsibility for the accuracy, completeness, or usefulness of any information, apparatus, product, or process disclosed, or represents that its use would not infringe privately owned rights. Reference herein to any specific commercial product, process, or service by trade name, trademark, manufacturer, or otherwise does not necessarily constitute or imply its endorsement, recommendation, or favoring by the United States Government or any agency thereof. The views and opinions of authors expressed herein do not necessarily state or reflect those of the United States Government or any agency thereof. 


\section{DISCLAIMER}

Portions of this document may be illegible in electronic image products. Images are produced from the best available original document. 
Printed in the United States of America. Available from

National Technical Information Service

U.S. Department of Commerce

5285 Port Royal Road, Springfield, Virginia 22161

Price: Printed Copy $\$ 5.00$; Microfiche $\$ 2.25$

This report was prepared as an account of work sponsored by the United States Government. Neither the United States nor the Energy Research and Development Administration, nor any of their employees, nor any of their contractors, subcontractors, or their employees, makes any warranty, express or implied, or assumes any legal liability or responsibility for the accuracy, completeness or usefulness of any information, apparatus, product or process disclosed, or represents that its use would not infringe privately owned rights. 
ORNL/TM- 5327

UC-2

Contract No. W-7405-eng-26

Information Division

MASTERS AND DOCTORATE THESES

ISSUED AS LABORATORY REPORTS

Elizabeth B. Howard

MARCH 1976

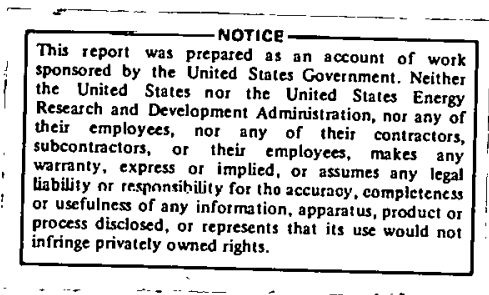

OAK RIDGE NATIONAI LABORATORY

Oak Ridge, Tennessee 37830

operated by

UNITON CARBIDE CORPORATION

for the

ENERGY RESEARCH AND DEVELOPMENT ADMINISTRATION 


\section{THIS PAGE}

WAS INTENTIONALLY

\section{LEFT BLANK}


CONTENTS

\section{Page}

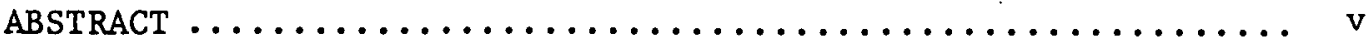

INTRODUCTION $\ldots \ldots \ldots \ldots \ldots \ldots \ldots \ldots \ldots \ldots \ldots \ldots \ldots \ldots \ldots \ldots$ v

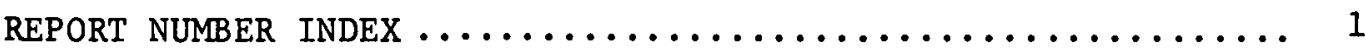

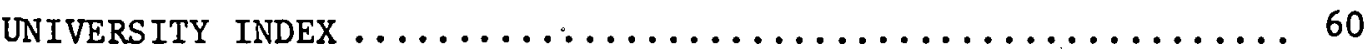

SUBJECT CATEGORY INDEX .......................... 64

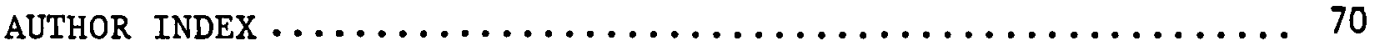




\section{THIS PAGE}

\section{WAS INTENTIONALLY \\ LEFT BLANK}


ABSTRACT

This is a compilation of the masters and doctorate theses that have been issued as reports by the Oak Ridge National Laboratory. The Laboratory has long encouraged the attainment of higher degrees by providing time, space, equipment, technical guidance and/or financial assistance. Many employees and students with fellowships or grants have completed, within the Laboratory, the work preceding the writing of a thesis. Some of the resultant master and doctorate theses have subsequently been Issued as regular Laboratory reports and thus been made available to a wide audience.

The report covers the period from 1950 through 1975 and includes indexes for authors, subject classification, and the school accepting the thesis.

\section{INTRODUCTION}

The Oak Ridge National Laboratory, from the early days of its existance, has encouraged and participated in training courses and educational activites. Laboratory facilities and trained personnel have been available since 1948 when the Atomic Energy Commission predoctoral and postdoctoral fellowships were established. Contacts and arrangements were made with such schools as the University of Tenneesee and Vanderbilt University concerning assignments, and many theses resulted from work completed in the Health Physics Division by students on AEC Fellowships in Radiological Physics. In 1956 an Education Assistance Program was started within the Laboratory and included financial assistance for course work. By 1967 an employee obtaining a graduate degree, and filling Company requirements, could expect to be reimbursed for all of his scholastic expenses.

of all the theses completed by employees, or those holding scholarships or grants, many have been issued as Laboraliry reports. 
ORNL numbers were used to February 1965, then ORNL-TM numbers also started to be assigned. The Division issuing a report has the responsibility of deciding if a formal ORNL number is to be used for a topical report, or the less formal ORNL-TM memo number. is to be assigned. As the Laboratory has expanded the scope of its programs, or thesls work has been completed under different sponsorships a few other number designations have been used.

This compllation starts with 1950, the earliest thesis report that could be verifled, and goes through 1975. Of the 435 theses listed, there: are 196 masters and 239 doctorates. In six instances the report is not the complete thesis, but based on such a substantial part that it has been included. The Technical Information Center of the former Atomic Energy Commission published five theses as TID reports and they also have been added.

When more than one author is listed for a report the first author is the one who submitted the thesis. The compilation is divided into four parts. The main bibliographic listing is by report number, with cross indexes to the number by the university to whom the thesis was submiteed, subject categories, and author.

The contributions of Juanita Ball of the Laboratory Records Department and Bobbie Kirtland of the Personnel Development and Systems Department are greatly acknowledged. 
REPORT NUMBER INDEX

CF REPORTS

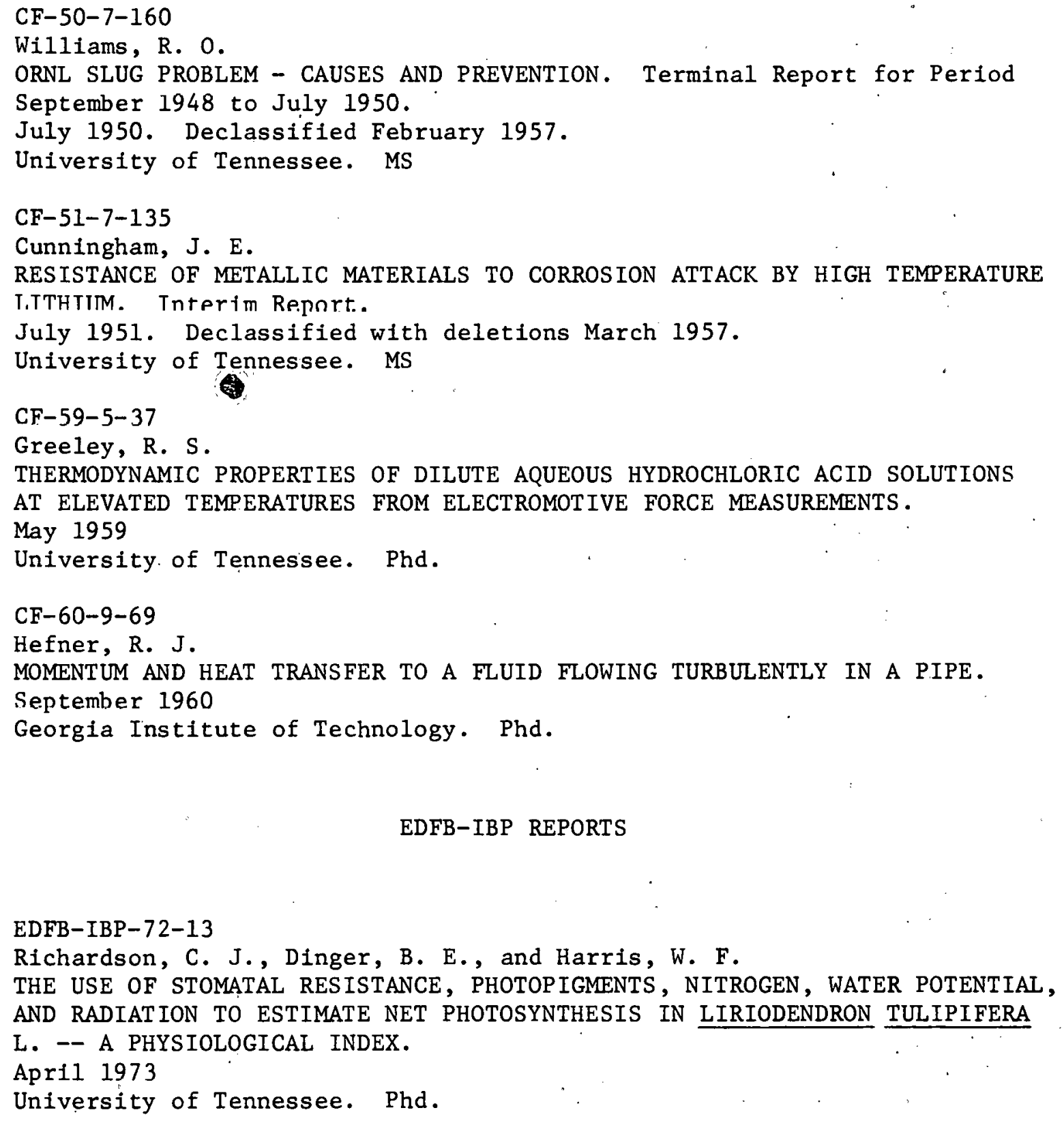


EDFB-IBP-73-2

Sollins, P., Reichle, D. E., and Olson, J. S. ORGANIC MATTER BUDGET AND MODEL FOR A SOUTHERN APPALACHIAN LIRIODENDRON FOREST.

Apr11 1973

University of Tennessee. Phd.

EDFB-IBP-73-8

McBrayer, J. F., Reichle, D. E., and Witkamp, M.

ENERGY FLOW AND NUTRIENT CYCLING IN A CRYPTOZOAN FOOD-WEB.

January 1974

University of Tennessee. Phd.

EDFB-IBP-73-10

Ausmus, B. S. and Witkamp, M.

LITTER AND SOIL MICROBIAL DYNAMICS IN A DECIDUOUS FOREST STAND.

February 1974

University of Tennessee. Phd.

ORNL REPORTS

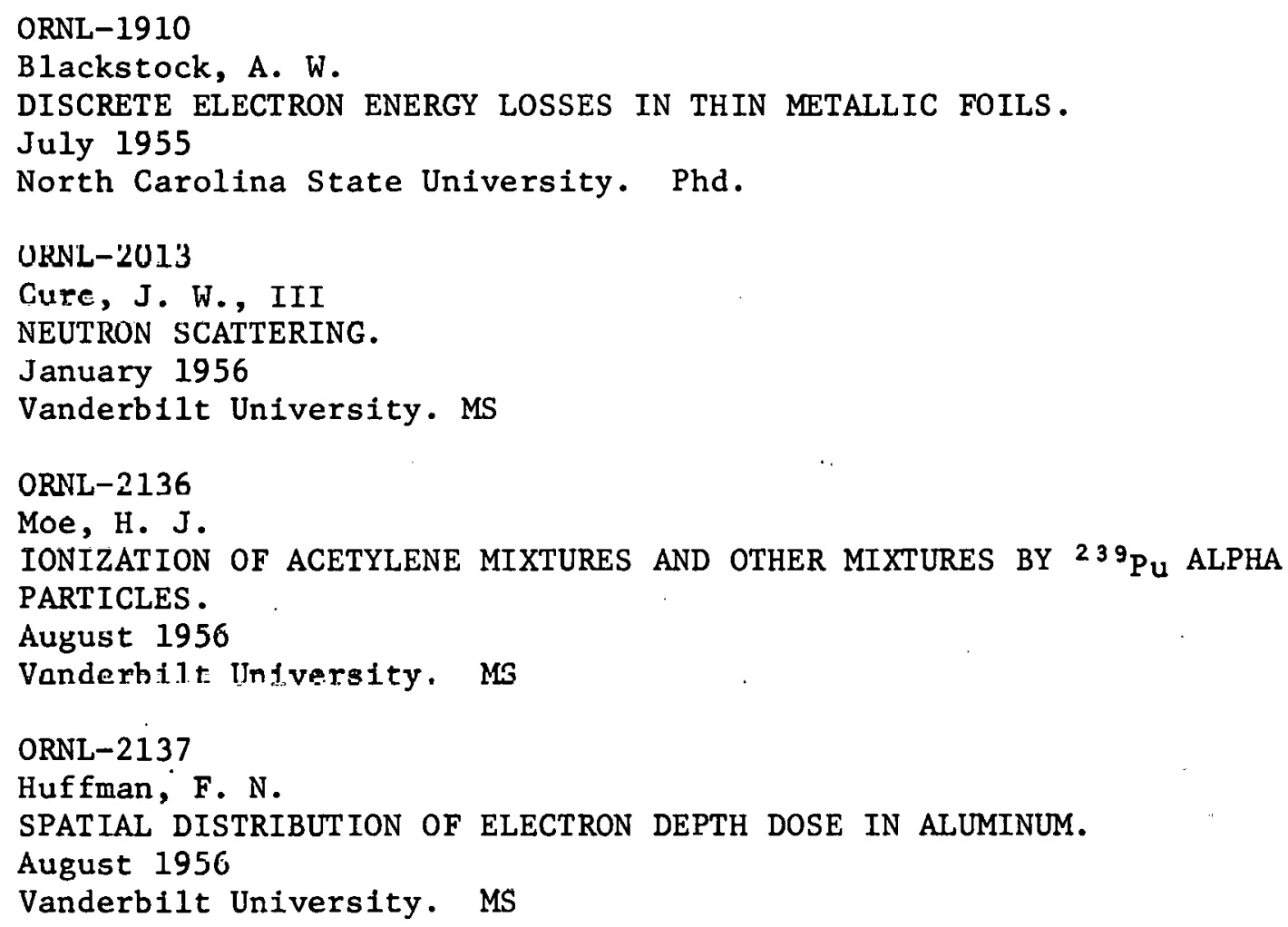


ORNL-2158

Johnson, R. M., Hubbell, H. H., Jr., and Birkhoff, R. D. POCKET ION CHAMBERS FOR BETA RADIATION DOSE.

May 1957

Vanderbilt University. MS

ORNL-2298

Johnston, L. W., Birkhoff, R. D., Cheka, J. S., Hubbell, H. H., Jr., and Saunders, B. G.

RESPONSE OF THE ANTHRACENE SCINTILLATION COUNTER TO LOW ENERGY

ELECTRONS.

May 1957

Vanderbilt University. MS

ORNL-2328

Scott, J. L.

A CALORIMETRIC INVESTIGATION OF ZIRCONIUM, TITANIUM, AND ZIRCONIUM

ALLOYS FROM 60 TO $960^{\circ} \mathrm{C}$.

Juiy 1957

University of Tennessee. Phd.

ORNL-2352

Patton, W. F., Hurst, G. S., and Bortner, T. E.

MEASUREMENT OF THE AVERAGE ENERGY LOST BY A 5 MEV ALPHA PARTICLE IN

PRODUCING AN ION PAIR IN WATER VAPOR.

September 1957

Vanderbilt University. MS

ORNL-2372

Page, J. P.

THE ANNEALING BEHAVIOR OF COLD-ROLLED NIOBIUM.

October 1957

University of Tennessee. MS

ORNL-2419

Blanchard, R. L., Kahn, B., and Birkhoff, R. D.

THE PREPARATION OF THIN, UNIFORM SOURCES FOR A BETA-RAY SPECTROMETER.

December 1957

Vanderbilt University. MS

ORNL-2521

Nelson, D. R., Birkhoff, R. D., Ritchie, R. H., and Hubbell, H. H., Jr. MEASUREMENT OF ELECTRON FLUX IN MEDIA BOMBARDED BY X-RAYS.

October 1958

Vanderbilt University. MS

ORNL-2524

Roche, T. K.

THE INFLUENCE OF COMPOSITION UPON THE $1500^{\circ} \mathrm{F}$ CREEP-RUPTURE STRENGTH AND MICROSTRUCTURE OF MOLYBDENUM-CHROMIUM-IRON-NICKEL BASE ALLOYS.

July 1958

University of Tennessee. MS 
ORNL-2529

Villforth, J. C., Birkhoff, R. D., and Hubbell, H. H., Jr.

COMPARISON OF THEORETICAL AND EXPERIMENTAL FILTERED X-RAY SPECTRA.

July 1958

Vanderbilt University. MS

ORNL-2533

Wende11, J. 3 .

EVIDENCE FOR THE UNIFORM RADIATION LIFE SHORTENING PREDICTED BY INFORMATION THEORY.

June 1958

Vanderbilt University. MS

ORNL-2534

Knowles, D. J.

A COMPUTER FOR A POSITION INDICATING SYSTEM.

August 1958

University of Tennessee. MS

ORNL-2535

Fisher, D. E.

NUCLEAR REACTION CROSS SECTIONS FROM THE NITROGEN BOMBARDMENT OF SULFUR.

July 1958

University of Florida. Phd.

ORNL-2549

Barker, J. A.

THE EFFECT OF THE "TENDENCY TO REPORT INJURIES" ON MINOR ACCIDENT STATISTICS.

August 1958

UnIversity of 'I'ennessee. MS

ORNL -2569

Olson, W. O., Hubbel1, H. H., Jr., and Birkhoff, R. D.

A STUDY OF PRE-ACCELERATION IN BETA-RAY SPF.TTROSCOPY.

October 1958

Vanderbilt University. MS

ORNL-257I

Pigan, E. A.

AN INVESTIGATION OF HOT DUCTILITY OF INCONEL AND INCONEL $\mathrm{x}$.

September 1958

Rensselaer Polytechnic Institute. MS

ORNL-2582

Thompson, E. G.

THE EFFECT OF SIMULATED WELD THERMAL CYCLES ON THE PROPERTIES OF HASTELLOY B.

October 1958

Rensselaer Polytechinc Institute. MS 


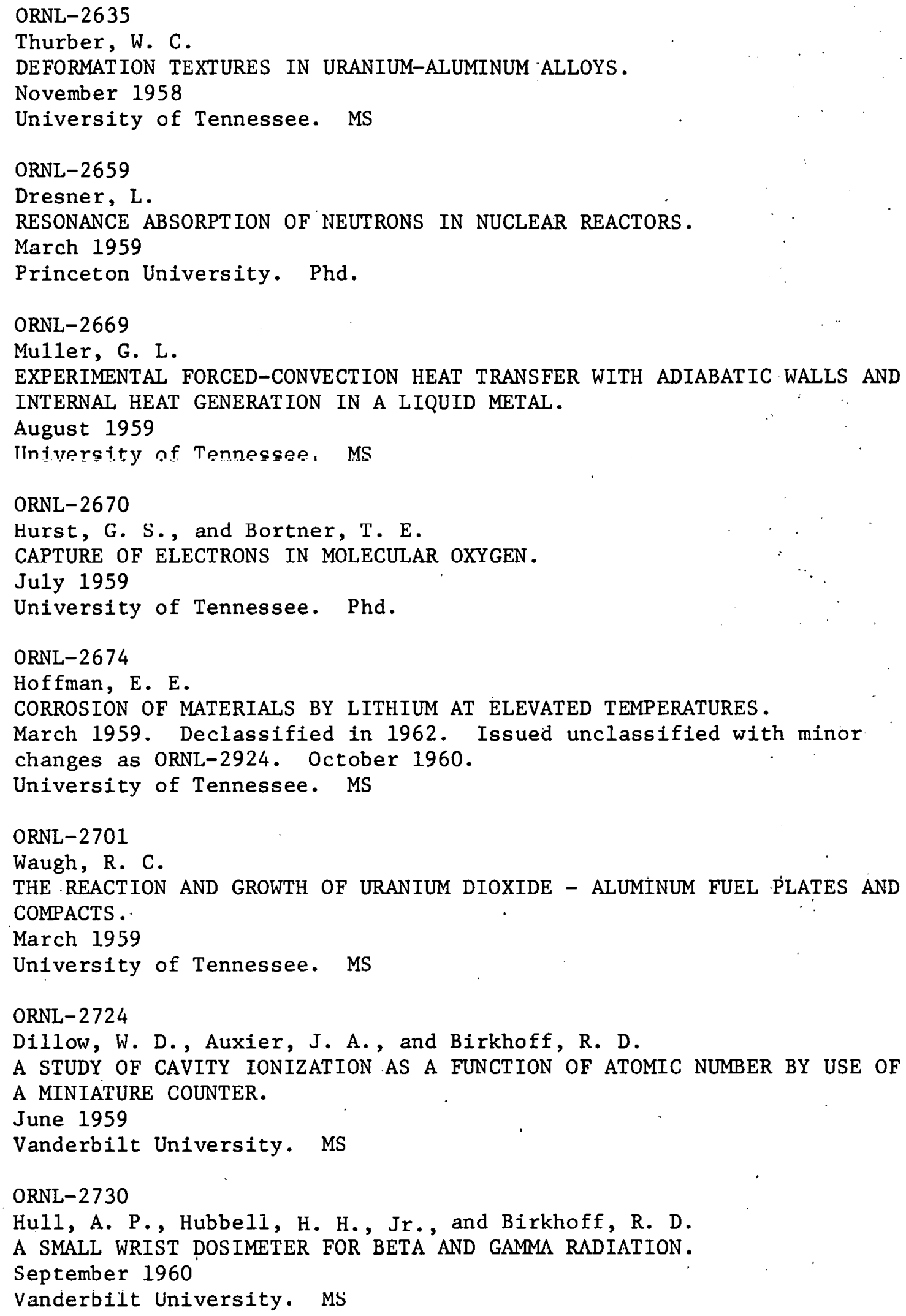


ORNL-2731

Kal11, F., Stone, W. G., Hubbell, H. H., Jr., and Blrkhoff, R. D. STOPPING POWER OF THIN ALUMINUM FOILS FOR 12 TO $127 \mathrm{KeV}$ ELECTRONS.

September 1959

Vanderbilt University. Phd.

ORNL-27.32

Finston, R. S., Hubbell, H. H., Jr., Stone, W. G., and Birkhoff, R. D. MEASUREMENT OF ELECTRON FLUX IN IRRADIATED MEDIA BY AC METHODS.

September 1959

Vanderbilt University. MS

ORNL-2742

Yee, W. C.

A STUDY OF THE EFFECTS OF FISSION FRAGMENT RECOILS ON THE OXIDATION OF. ZIRCONIUM.

April 1960

University of Tennessee. MS

ORNL-2755

Lee, P. K., and Auerbach, S. I.

DETERMINATION AND EVALUATION OF THE RADIATION FIELD ABOVE WHITE OAK

LAKE BED.

September 1959

Vanderbilt University. MS

ORNL-2775

Zlemer, P. L., Johnson, R. M., and Birkhoff, R. D.

MEASUREMENT OF STOPPING POWER OF COPPER BY CALORIMETRIC METHODS.

Deceniberi 1959

Väiderilll UnLversily. MS

ORNL-2783

Gilliland, J. W., Jr.

THERMOLUMINESCENCE STUDIES OF THE GAMMA-IRRADIATED FERROELECTRICS

ROCHELLE SALT AND GUANIDINE ALUMINUM SULFATE HEXAHYDRATE.

Auguar 1959

Vanderbilt University. MS

ORNL-2804

Schaibe, C. H.

A VERSATILE INSTRUMENT CAMERA WITH A MICROSECOND ELECTRONIC SHUTTER.

October 1959

University of Tennessee. MS

ORNL-2807

Sanders, F. W., Hurst, G. S., and Bortner, T. E.

A STUDY OF ALPHA PARTICLE IONIZATION IN ARGON MIXTURES.

October 1959

Vanderbilt University. MS 
ORNL-2860

Ziegler, N. F.

THE ADMITTANCE AND TRANSFER FUNCTIONS OF SOLID CORE ELECTROMAGNETS.

December 1959

University of Tennessee. MS

ORNL-2862

Goldstein, G.

A STUDY OF SPECTROPHOTOMETRIC METHODS FOR THE DETERMINATION OF OSMIUM. January 1960

University of Tennessee. MS

ORNL-2885

Forsberg, H. C.

THERMODYNAMIC PROPERTIES OF THE URANIUM MERCURIDES.

February 1960

University of Louisville. Phd.

ORNL-2887

$0^{\prime}$ Kelly, L.'B., Hurst, G. S., and Bortner, T. E.

MEASUREMENT OF ELECTRON ATTACHMENT IN OXYGEN-METHANE AND OXYGEN

CARBON-DIOXIDE MIXTURES .

January 1960

Vanderbilt University. MS

ORNL-2912

Thornton, W. T., and Auxier, J. A.

SOME X-RAY AND FAST NEUTRON RESPONSE CHARACTERISTICS OF SILVER'

METAPHOSPHATE GLASS DOSIMETERS.

August 1960

Vanderbilt University. MS

ORNL-2919

Hanauer, S. H., Dabbs, J. W. T., Roberts, L. D., and Parker, G. W. THE ANGULAR DISTRIBUTION OF ALPHA PARTICLES EMITTED BY ORIENTED ${ }^{237} \mathrm{~Np}$ NUCLEL .

May 1960

University of Tennessee. Phd.

ORNL-2924

See ORNL-2674

ORNL-2933

Datz, S.

MOLECULAR ASSOCIATION IN ALKALI HALIDE VAYUKS.

May 1960

University of Tennessee. Phd.

ORNL-2946

Leitten, C. F., Jr.

THE STABILITY OF EUROPIUM OXIDE IN SILICON-BEARING STAINLESS STEEL.

August 1960

University of Tennessee. MS 


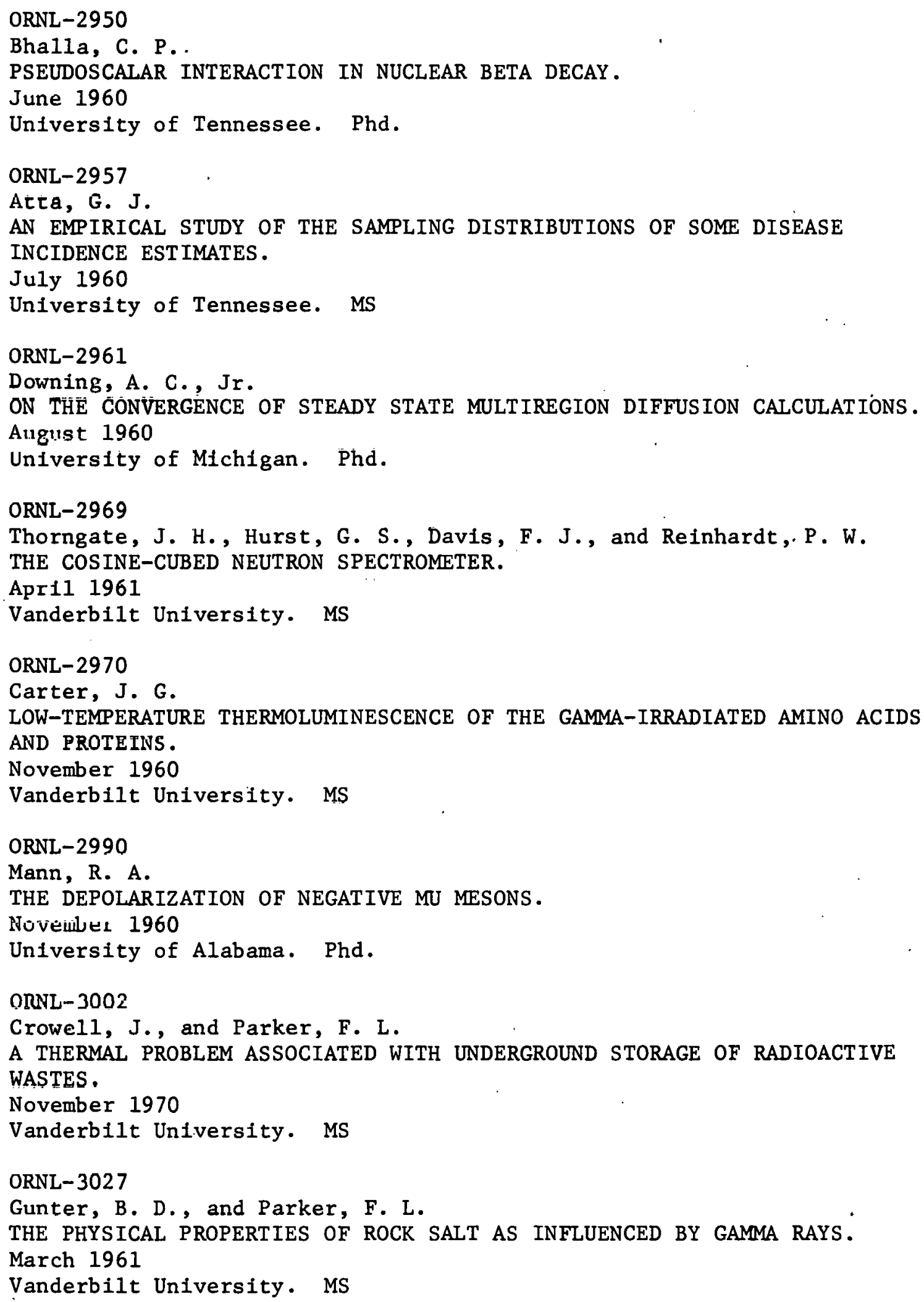


ORNL-3033

Zerby, C. D.

ELECTROMAGNETIC PRODUCTION OF PION PAIRS.

January 1961

University of Tennessee. Phd.

ORNL-3052

Holmberg, R. W.

A PARAMAGNETIC RESONANCE STUDY OF HYPERFINE INTERACTIONS IN SINGLE CRYSTALS CONTAINING $\alpha, \alpha$-DIPHENYL- $\beta$-PICRYLHYDRAZYL.

January 1971

University of Tennessee. Phd.

ORNL -3057

Staum, M. M.

THE DEAMINATION AND REARRANGEMENT OF erythro-1-AMINO-1-PHENYL-2-0-

TOLYL-2-PROPANOL.

August 1961

University of Florida. Phd.

ORNL-3091

Forester, D. W., and Cochran, L. W.

DIFFUSION OF SLOW ELECTRONS IN GASES.

September 1961

University of Tennessee. MS

ORNL-3098

May, F. T.

THE DEVELOPMENT OF A DIRECT COUPLED, TRANSISTORIZED, SUB-MILLIMICROAMPERE CURRENT AMPLIFIER.

Ju1y 1961

University of Tennessee. MS

ORNL-3108

Curtis, O. L., and Crawford, J. H., Jr.

THE CARRIER-RECOMBINATION BEHAVIOR AND ANNEALING PROPERTIES OF RADIATION-

INDUCED RECOMBINATION CENTERS IN GERMANIUM.

May 1961

University of Tennessee. Phd.

ORNL-3109

Chester, C. V.

AN INVESTIGATION OF THE TRANSFER OF URANYL NITRATE ACROSS THE WATER--

TRIBUTYL PHOSPHATE INTERFACE BY THE METHOD OF PHOTOGRAPHIC PHOTOMETRY.

May 1961

University of Tennessee. MS

ORNL-3114

Frank, A. L., Arakawa, E. T., Birkhoff, R. D., Ritchie, R. H., and Eldridge, H. B.

OPTICAL EMISSION FROM IRRADIATED THIN METALIIS FOTLS.

July 1.962

Vanderbilt University. MS 
ORNL-3115

Weinberg, C. J., Carter, J. G., Nelson, D. R., and Birkhoff, R. D.

THERMOLUMINESCENCE SPECTRA AND ACTIVATION ENERGIES FOR AROMATIC AMINO ACIDS, TRYPSIN, AND SPORES OF BACILLUS MEGATERIUM.

June 1963

Vanderbilt University. MS

ORNL-3141

Cherubini, J. H. DETERMINATIONS OF THE KINETICS AND MECHANISMS OF DEBORONIZATION AT $1135^{\circ} \mathrm{C}$.

August 1961

University of Tennessee. MS

ORNL -31.52

Ward, J. C.

RADIOACTIVITY OF NUCLEAR REACTOR COOLING FLUIDS.

September $\cdot 1961$

University of Oklahoma. Phd.

ORNL-3172

Neel, R. B., and 01son, J. S.

USE OF ANALOG COMPUTERS FOR SIMULATING THE MOVEMENT OF ISOTOPES IN ECOLOGICAL SYSTEMS.

January 1962

Vanderbilt University. MS

ORNL-3292

Scott, C. D.

THE RATE OF REACTION OF HYDROGEN FROM HYDROGEN-HELIUM STREAMS WTTH FIXED BEDS OF COPPER OXIDE.

July 1962

UnIversity of Tennessee. MS

ORNL-3294

Colwal1, G. T.

AN AERODYNAMIC-THERMODYNAMIC STUDY OF CENTRIFUGAL COMPRESSORS.

December 1962

University of Tennessee. MS

UKNL-3296

Watoon, J. Si.

A STUDY OF THE KINETICS OF URANYL SULFATE EXCHANGE WITH A STRONG BASE ANION RESIN.

July 1962

University of Tennessee. MS 
ORNL-3306

Lamphere, R. W.

THE ANGULAR DISTRIBUTION OF FISSION FRAGMENTS FROM THE FAST NEUTRONINDUCED FISSION OF U-234.

August 1962

University of Tennessee. Phd.

ORNL- 3328

Witherspoon, J. P., Jr., Auerbach, S. I., and 0lson, J. S.

CYCLING OF CESIUM-134 IN WHITE OAK TREES ON SITES OF CONTRASTING SOIL TYPE AND MOISTURE.

October 1962

Universtty of Tennessee. Phd.

ORNL-3346

Sims, T. M.

LOW TEMPERATURE THERMOLUMINESCENCE OF GAMMA IRRADIATED POTASSIUM

DIHYDROCEN PHOEPHATE.

October 1962

Vanderbilt University. MS

ORNL-3354

Gwin, R., and Murray, R. B.

STUDIES OF THE SCINTILLATION PROCESS IN CsI(Tl).

October 1962

University of Tennessee. Phd.

ORNL-3383

Bertini, H. W.

MONTE CARLO CALCULATIONS ON INTRANUCLEAR CASCADES.

April 1963

University of Tennessee. Phd.

ORNL-3390

Cooke, J. W.

THE EXPERIMENTAL DETERMINATION OF THE THERMAL CONDUCTIVITY OF MOLTEN

LITHIUM FROM 600 TO 1550 DEGREES FAHRENHEIT.

January 1964

University of Tennessee. MS

ORNL-3422

Edmundson, M., Bortner, T. E., Hurst, G. S., and Parks, J. E.

ALPHA PARTICLE IONIZATION OF ARGON MIXTURES - FURTHER STUDY OF THE ROLE OF EXCITED STATES.

May 1963

Vanderbilt University. MS 
ORNL-3438

Gilliland, R. G.

INVESTIGATION OF THE WETTABILITY OF VARIOUS PURE METALS AND ALLOYS ON BERYLLIUM.

May 1963

University of Tennessee. MS

ORNL-3443

Pigg, J. C.

ANNEALING OF GAMMA RAY INDUCED CHANGES IN ANTIMONY DOPED GERMANIUM.

May 1963

University of Tennessee. Phd.

ORNL-3450

Emeroon, L. C., Arakawa, E. T., Ritchle, R. H., and Blikhoff, R. I. EMISSION SPECTRA OF ELECTRON IRRADIATED METAL FOILS.

Iuly 1903

University of Tennessee. Phd

ORNL-3463

McConnell, W. J., Hubbell, H. H., Jr., and Birkhoff, R. D.

ELECTRON-SLOWING-DOWN SPECTRUM IN Cu OF BETA RAYS FROM ${ }^{64} \mathrm{Cu}$.

May 1964

Vanderbilt University. MS

ORNL-3468

Hammer, D. C., Arakawa, E. T., Emersnn, T. C., and Birkhoff, R. D.

OPTICAL EMISSION FROM ELECTRON IRRADIATED THIN GOLD FOILS.

August 1963

Vauderb1lt Universicy. MS

ORNL-3469

Wilkie, W. H., and Birkhoff, R. D.

MEASUREMENT OF SPECTRAL DISTRIBUTION OF POSITRON FLUX IN AN INFINITE COPPER MEDIUM CONTAINING ${ }^{64} \mathrm{Cu}$.

December 1963

Vanderbilt University. MS

ORNL-3473

Northup, T. E.

HIGH DENSITY SLAG CONCRETE.

July 1963

University of Tennessee. MS

ORNL- 3484

LaBar, D. A., Harter, J. A., and Birkhoff, R. D. I'LME-UF-FLIGHT STUDIESS OF ELECTRONS IN VACUUM.

April 1964

Vanderbilt University. MS 
ORNL- 3485

Davis, N. O., Arakawa, E. T., Emerson, L. C., and Birkhoff, R. D. THE ANGULAR AND SPECTRAL DISTRIBUTIONS OF LIGHT EMITTED FROM ELECTRONBOMBARDED SILVER FOILS.

March 1964

Vanderbilt University. MS

ORNL -3486

Mruk, W. F.

THE PRINCIPLES AND MEASUREMENT OF FISSION-FRAGMENT TIMES OF FLIGHT.

August 1963

University of Tennessee. Phd.

ORNL-3494

McNeese, L. E.

AN EXPERIMENTAL STUDY OF SORPTION OF URANIUM HEXAFLUORIDE BY SODIUM

FLUORIDE PELLETS AND A MATHEMATICAL ANALYSIS OF DIFFUSION WITH

STMITITANFIIIS RF.ACTTINN.

November 1963

University of Tennessee. MS

ORNL-3507

Cain, V. R.

CALCULATIONS OF THERMAL-NEUTRON FLUX DISTRIBUTIONS IN CONCRETE-WALLED DUCTS USING AN ALBEDO MODEL WITH MONTE CARLO TECHNIQUES.

January 1964

University of Tennessee. MS

ORNL- 3510

Godbee, H. W.

THERMAL CONDUCTIVITY OF MAGNESIA, ALUMINA, AND ZIRCONIA POWDERS IN AIR AT ATMOSPHERIC PRESSURE FROM $200^{\circ} \mathrm{F}$ TO $1.500^{\circ} \mathrm{F}$.

April 1966

Georgia Institute of Technology. Phd.

ORNL -3527

Haas, P. A.

ENGINEERING DEVELOPMENT OF A FOAM COLUMN FOR COUNTERCURRENT SURFACELIQUID EXTRACTION OF SURFACE-ACTIVE SOLUTES.

June 1965

University of Tennessee. Phd.

ORNL- 3530

Martin, R. E., Auerbach, S. I., and Nelson, D. J.

GROWTH AND MOVEMENT OF SMALLMOUTH BUFFALO, ICITTOBUS BUBALUS

(RAFINESQUE), IN WATTS BAR RESERVOIR, TENNESSEE.

January 1964

University of Tennessee. Phd. 
ORNL-3531

Blaylock, B. G., Auerbach, S. I., and Nelson, D. J.

CHROMOSOMAL ABERRATIONS IN A NATURAL POPULATION OF CHIRONOMUS TENTANS

EXPOSED TO CHRONIC LOW-LEVEL ENVIRONMENTAL RADIATION.

January 1963

University of Tennessee. Phd.

ORNL-3551

Distefano, J. R.

CORROSION OF REFRACTORY METALS BY LITHIUM.

March 1964

University of Tennessee. MS

ORNL-3563

Eergent, J. E.

THE EFFECT OF THE "TENDENCY TO REPORT INJURIES" ON MINOR ACCIDENT

STATISTICS: A FOLLOW-UP STUDY.

February 1964

University of Tennessee. MS

ORNL-3595

Hanna, M. G, J Jr:

AN AUTORADIOGRAPHIC AND HISTOLOGIC STUDY OF SPLEEN WHITE PULP GERMINAL CENTERS DURING EARLY INTERVALS OF THE PRIMARY IMMUNE RESPONSE.

May 1964

University of Tennessee. Phd.

ORNL-3600

McCoy, H. E., Jr.

EFFECTS OF HYDROGEN ON THE HIGH-TEMPERATURE FLOW AND FRACTIIRF.

CHARACTERISTICS OF METALS.

June 1964

University of Tennessee. Phd.

ORNL -3615

Harlow, M. V., Jr.

THE YIELD OF ELASTICALLY SCATTERED 17 TO $21 \mathrm{MeV}$ NEUTRONS FROM THE

REACTION $\mathrm{C}^{12}(\mathrm{n}, \mathrm{n}) \mathrm{C}^{12}$.

June 1964

University of Texas. Phd.

UKNL-J610

Murdock, J. F.

DIFFUSION OF TITANIUM-44 AND VANADIUM-48 IN TITANIUM.

June 1964

University of Tennessee. MS 
ORNL-3617

Lundy, T. S.

DIFFUSION IN BODY-CENTERED CUBIC METALS ZIRCONIUM, VANADIUM, NIOBIUM, AND TANTALUM.

June 1964

University of Tennessee. Phd.

ORNL-3635

Purcel1, T.

PARAMAGNETIC CENTERS IN GERMANIUM DIOXIDE GLASS PRODUCED BY ELECTRON AND GAMMA-RAY IRRADIATION.

June 1964

Vanderbilt University. MS

ORNL-3638

Sweet, R. F.

MEASUREMENT AND SHELL MODEL INTERPRETATION OF THE LOW-LYING NUCLEAR ENERGY LEVELS OF NIOBIUM-92.

June 1964

University of Texas. Phd.

ORNL-3646

Zettl, A.

RELATED TWO POINT BOUNDARY VALUE PROBLEMS AND ASSOCIATED HARMONIC

MATRICES .

September 1965

University of Tennessee. Phd.

ORNL-3655

LaTorre, D. R.

ON THE RADICAL OF A HEMIRING.

July 1965

University of Tennessee. Phd.

ORNL-3657

Anderson; T, D.

AN INVESTIGATION OF THE INFLUENCE OF THE HOLDUP EFFECT OF DOUBLE

CONTAINMENT ON REACTOR HAZARDS.

September 1964

University of Tennessee. MS

ORNL -3678

Hobson, D. 0 .

DEFORMATION TWINNING IN THE COLUMBIUM-VANADIUM ALLOY SYSTEM.

September 1964

University of Tennessee. MS 
ORNL-3682

Warner, A. H.

ISOLATION, PURIFICATION, AND SOME PROPERTIES OF $\mathrm{P}^{1}, \mathrm{P}^{4}-$ DIGUANOSINE

$5^{\prime}$-TETRAPHOSPHATE asymmetrical-PYROPHOSPHOHYDROLASE FROM BRINE SHRIMP EGGS .

October 1964

University of Southern Illinois. Phd.

ORNL-3685

Oakes, L. C.

A REACTIVITY COMPUTER FOR USE WITH NUCLEAR REACTOR CONTROL SYSTEMS. September 1964

University of Tennessee. MS

ORNL-3688

Clanton, D. H.

SOME ALGORITHMS FOR THE CALCULATION OF THE GILARACTERIJTIC ROOT3 AND

VECTORS OF A NORMALIZABLE MATRIX.

October 1964

Auburn University. Phd.

ORNL-3692

Kikèr, W. H.

CORRELATED ENERGY AND TIME-OF-FLIGHT MEASUREMENTS OF FISSION FRAGMENTS.

October 1964

University of Tennessee. Phd.

ORNL-3694

Joknison, G. G.

CONCERNING THE MOMENT PROBLEM.

Deceuber 1965

University of Tennessee. Phd.

ORNL-3696

Soper, G. K.

STUDIES OF THE ION-CYCLOTRON RESONANCE INSTABILITY.

Octoher 1964

University of Tennessee. Phd.

ORNL-3702

Rocokloin, A. K., Nalcai, M. Y., Arakawa, E. T., 3tanfurd, J. L., and Bi.rkhoff, R, D.

A NEW TECHNIQUE FOR MEASURING RANGE OF LOW ENERGY CHARGED PARTICLES IN CONDUCTING SOLIDS.

March 1965

Vanderbilt University. MS 
ORNL-3705

Forester, D. W.

MOSSBAUER STUDIES OF THE HYPERFINE STRUCTURE SPECTRA OF ${ }^{57} \mathrm{FE}$ IN FERh

ALLOYS, A- $\mathrm{Fe}_{2} \mathrm{O}_{3}$ AND $\mathrm{FeNH}_{4}\left(\mathrm{SO}_{4}\right)_{2} \cdot 12 \mathrm{H}_{2} \mathrm{O}$.

November 1964

University of Tennessee. Phd.

ORNL-3717

Muir, R. B.

A STUDY OF HYPERON PRODUCTION BY $430 \mathrm{MeV} / \mathrm{c} \mathrm{K}^{-}$-MESONS IN HELIUM.

November 1964

University of Tennessee. Phd.

ORNL-3743

Burrus, W. $R$

UTILIZATION OF A PRIORI INFORMATION BY MEANS OF MATHEMATICAL PROGRAMMING IN THE STATISTICAL INTERPRETATION OF MEASURED DISTRIBUTIONS.

June 1965

Ohio State University. Phd.

ORNL-3751

Litman, A. P.

THE EFFECT OF OXYGEN ON THE CORROSION OF NIOBIUM BY LIQUID POTASSIUM.

July 1965

University of Tennessee. MS

ORNL-3764

Chang, J. Y.

STUDIES ON EFFECTS OF DEPOSITION CONDITIONS AND HEAT TREATMENT ON THE PROPERTIES OF PYROLYTIC CARBON.

March 1965

University of Tennessee. MS

ORNL -3767

Chester, R. 0 .

RADIATION DAMAGE IN CADMIUM SULFIDE AND CADMIUM TELLURIDE.

March 1965

University of Tennessee. Phd.

ORNL-3873

Manson, A. R.

MINIMUM BIAS DESIGNS FOR AN EXPONENTIAL RESPONSE.

February 1966

Virginia Polytechnic Institute. Phd.

ORNL-3907

O'Farrell, T. P., Auerbach, S. I., and Dunaway, P. B.

INCORPORATION OF A THYMIDINE ANALOG BY INDIGENOUS RODENTS.

March 1966

University of Tennessee. Phd.

ORNT, -3914

Roskies, R.

R-MATRIX APPROACH TO COMPLEX ANGULAR MOMENTUM AND TO THREE-P.ARTICLE INTERACTION.

Princeton University. Phd. 


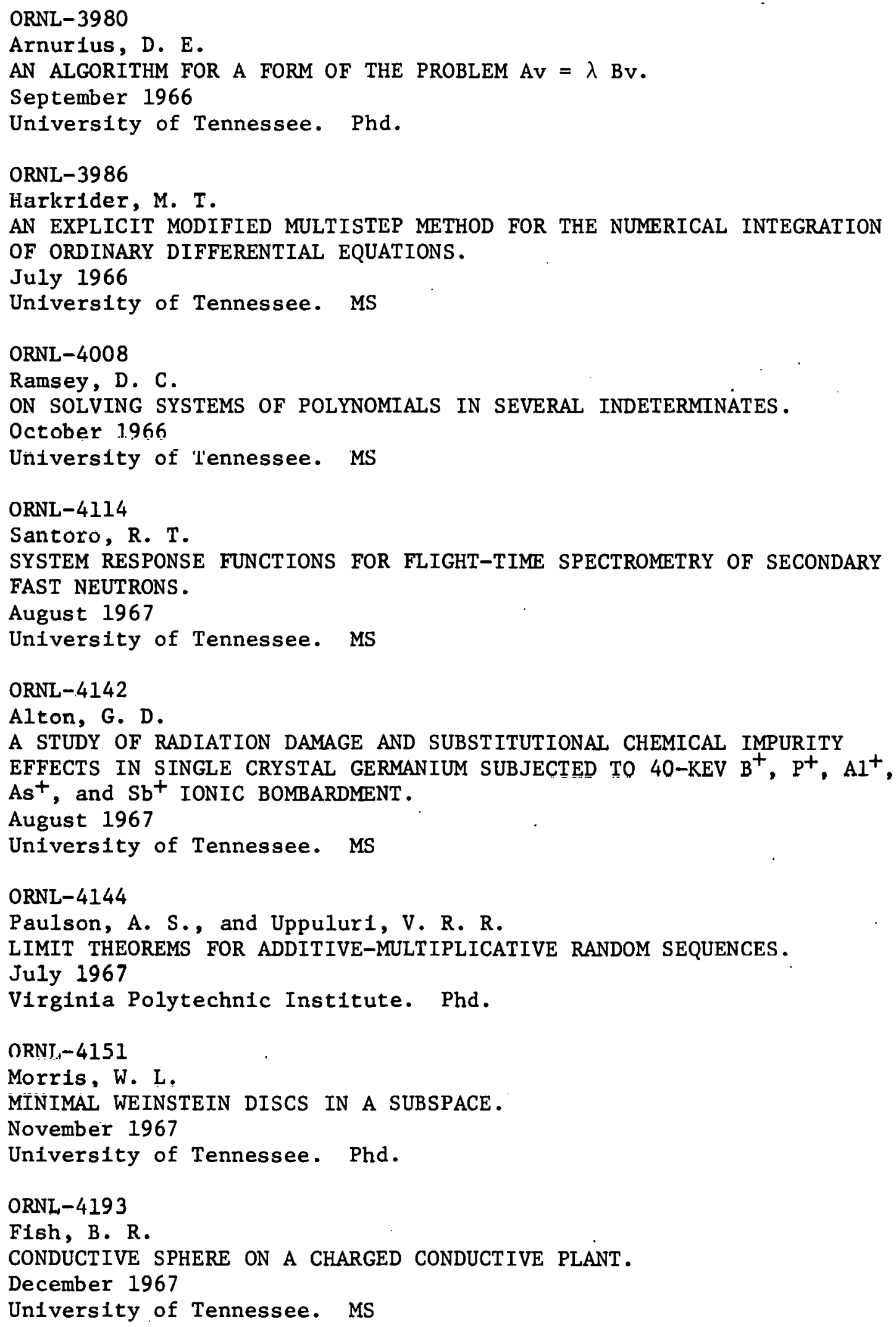


ORNL-4208

Tittle, R. L.

INFORMATION THEORY IN SEQUENTIAL ANALYSIS.

January 1968

University of Tennessee. Phd.

ORNL -4225

Lever, W. E.

PART 1 - THE LIMITING DISTRIBUTION OF THE LIKLIHOOD RATIO STATISTIC -

21.n $\lambda_{n}$ UNDER A CLASS OF LOCAL ALTERNATIVES. PART 2 - MINIMUM AVERAGE

RISK DECISION PROCEDURES FOR THE NONCENTRAL CHI-SQUARE DISTRIBUTION.

March 1968

Florida State University. Phd.

ORNL-4274

Bertrand, F. E., Peele, R. W., Love, T. A., Hill, N. W., and Burrus, W. R. DIFFERENTIAL CROSS SECTIONS FOR THE CHARGED PARTICLES PRODUCED BY 60-MeV PRÜTUNSS ÜN CARBON, IRON, AND BISMUTH

July 1968

Louisiana State University. Phd.

ORNL-4303

Stewart, G. W., III

SOME TOPICS IN NUMERICAL ANALYSIS.

September 1968

University of Tennessee. Phd.

ORNL-4310

Kelly, J. M., Opstrup, P. A., Olson, J. S., Auerbach, S. I., and

Van Dyne, G. M. (Submitted by first and second authors)

MODELS OF SEASONAL PRIMARY PRODUCTIVITY IN EASTERN TENNESSEE FESTUCA

AND ANDROPOGON ECOSYSTEMS.

June 1969

University of Tennessee. MS

ORNL -4318

Ragsdale, H. L., Witherspoon, J. P., and Nelson, D. J.

THE EFFECTS OF BIOTIC COMPLEXITY AND FAST NEUTRON RADIATION ON CESIUM-137

AND COBALT-60 KINETICS IN AQUATIC MICROCOSMS.

December 1968

University of Tennessee. Phd.

ORNL-4321

Cutler, N. E.

THE ALTERNATIVE EFFECTS OF GENERATIONS AND AGING UPON POLITICAL BEHAVIOR: A COHORT ANALYSIS OF AMERICAN ATTITUDES TOWARD FOREIGN POLICY, 1946 1966.

December 1968

Northwestern University. Phd. 
ORNL-4339

Adair, H. L.

A STUDY OF THE ${ }^{11} \mathrm{~B}\left({ }^{3} \mathrm{He}, \mathrm{p}\right)^{13} \mathrm{C}$. AND ${ }^{11} \mathrm{~B}\left({ }^{3} \mathrm{He},{ }^{3} \mathrm{He}\right)^{11} \mathrm{~B}$ REACTIONS

January 1969

University of Tennessee. MS

QRNL-4391

Moore, S. E.

AN ANISOTROPIC ELASTIC-PLASTIC STRESS ANALYSIS OF A THICK-WALLED

GRAPHITE CYLINDER.

Apri1 1969

University of Tennessee. MS

ORNL-4445

Kolehmalneu, 3. E., and Nelson, D. J.

THE BALANCE OF ${ }^{137} \mathrm{Cs}$, STABLE CESIUM AND THE FEEDING RATES OF BLUEGILL (LEPOMIS MACROCHIRUS RAF.) IN WHITE OAK LAKE.

December 1969

University of Tennessee. Phd.

ORNL -4452

Moulder, B. C., Reichle, D. E., and Auerbach, S. I. SIGNIFICANCE OF SPIDER PREDATION IN THE ENERGY DYNAMICS OF FOREST ARTHROPOD COMMUNITIES .

January 1970

University of Tennessee. Phd.

ORNL -44.58

Wantland, J. L.

A NUMERICAL EVALUATION OF THE VELOCITY AND TEMPERATURE STRUCTURE IN LAMINAR CELLULAR CONVECTION BETWEEN PARALLEL RIGID SURFACES.

December 1969

University of Tennessee. Phd.

ORNL -4479

Kurtz, L. A CONDENSATION ON FLUTED SURFACES.

December 1969

University of Tennessee. Phd.

ORNL-4504

Werner, W. J.

AN INVESTIGATION OF THE EFFECT OF CERTAIN MINOR ELEMENTS ON THE

ELEVATED TEMPERATURE DUCTILITY OF INCOLOY 800.

March 1970

University of Tennessee. MS 
ORNL-4509

Van Hook, R. I., Reichle, D. E., and Auerbach, S. I.

ENERGY AND NUTRIENT DYNAMICS OF PREDATOR AND PREY ARTHROPOD

POPULATIONS IN A GRASSLAND ECOSYSTEM.

March 1970

Clemson University. Phd.

ORNL-4561

Sessions, C. E.

INFLUENCE OF TITANIUM ON THE HIGH-TEMPERATURE DEFORMATION AND FRACTURE BEHAVIOR OF SOME NICKEL BASED ALLOYS.

July 1970

University of Tennessee. Phd.

ORNL-4568

Baker, C. E., Dunaway, P. B., and Auerbach, S. I.

RELATIONSHIP OF CESIUM-137 AND IRON-59 ELIMINATION RATES TO METABOLIC

RATES OF SMALL RODENTS.

July 1990

University of Tennessee. Phd.

ORNL-4580

Bloom, E. E.

AN INVESTIGATION OF FAST NEUTRON RADIATION DAMAGE IN AN AUSTENITIC

STAINLESS STEEL.

August 1970

University of Tennessee. Phd.

ORNL-4610

Harris, W. F., Witherspoon, J. P., and Olson, J. S.

ECOLOGICAL ASPECTS OF RESPONSES OF LIRIODENDRON TULIPIFERA L. AND ACER SACCHARINUM L. TO FAST NEUTRON RADIATION AND REDUCED LIGHT.

November 1970

University of Tennessee. Phd.

ORNL $=4612$

Cooley, J. L., and Nelson, D. J.

EFFECTS OF CHRONIC IRRADIATION AND TEMPERATURE ON POPULATIONS OF THE AQUATIC SNAIL PHYSA HETEROSTROPHA.

November 1970

University of Tennessee. Phd.

ORNL-4686

Feliciano, M., Jr.

GEOMETRIC PROPERTIES OF SOLUTIONS OF THE DIFFERENTIAL SYSTEM $x^{\prime}=A x$.

May 1971

University of Tennessee. Phd. 
ORNL -4700

DeRouen, T. A., and Mitchell, T. J.

BAYES-SUGGESTED SOLUTIONS IN BINOMIAL ESTIMATION.

August 1971

Virginia Polytechnic Institute. Phd.

ORNL-4808

Rallile, R. P.

HEAT TRANSFER IN A GAS-COOLED, HEAT GENERATING POROUS SOLID.

December 1972

Pennsylvania State University. Phd.

ORNL -4826

Alton, G. D., Garrett, W. R., and Turner, J. E.

ELECTRON SCATTERING FROM SIMPLE ATOMIC AND MOLECULAR SYSTEMS; A STUDY

OF THE PHENOMENOLOGICAL AND MICROSCOPIC OPTICAL MODELS.

November 1972

University of Tennessee. Phd.

ORNL -4850

Fields, D. E., and Moran, P. R.

A STUDY OF CORRELATED THERMALLY ACTIVATED POLARIZATION, CONDUCTION, AND LUMINESCENCE EFFECTS IN LITHIUM FLUORIDE AS FUNCTIONS OF IRRADIATION, DOPING, AND THERMAL HISTORY. Part of thesis "Influence of Irradiation and Doping on Thermally Activated Polarization and Luminescence in Lithium Fluoride"

March 1973

University of Wisconsin. Phd.

ORNL- 4876

Dusenberry, W. E., and Bowman, K. 0 .

PERCENTAGE POINTS OF MOMENT ESTIMATORS WHICH ARE RATIOS WITH AN

APPLICATION TO THE SHAPE PARAMETER OF THE GAMMA DISTRIBUTION.

May 1973

Virginia Polytechnic Institute. Phd.

ORNL-4893

Kelly, J. M.

DYNAMICS OF LITTER DECOMPOSITION, MICROBIOTA POPULATIONS, AND NUTRIENT MOVEMENT FOLLOWING NITROGEN AND PHOSPHORUS ADDITIONS TO A DECIDUOUS FOREST STAND.

.Tu1y 1973

University of Tennessee. Phd.

ORNL-4953

Rust, B. W.

THE USE OF SUPERNOVAE LIGHT CURVES FOR TESTING THE EXPANSION HYPOTHESIS AND OTHER COSMOLOGICAL RELATIONS.

December 1974

University of Illinois. Phd. 
ORNL-4957

Heath, M. T.

THE NUMERICAL SOLUTION OF ILL-CONDITIONED SYSTEMS OF LINEAR EQUATIONS. Part of Thesis.

July 1974

University of Tennessee. MS

ORNL-4987

Chapman, R. H.

SATURATED POOL AND FLOW BOILING STUDIES WITH FREON-113 AND WATER AT ATMOSPHERIC PRESSURE.

November 1974

University of Tennessee. Phd.

ORNL-5051

Chang, J. Y.

HOT-PRESSURE STUDY ON MIXED URANIUM-PLUTONIUM NITRIDE FOR ADVANCED

REACTOR FUEL.

November 1975

University of Inha. Korea. Phd.

ORNL-5088

Copeland, G. L.

AN INVESTIGATION OF ALLOYING EFFECTS IN ALUMINUM DISPERSION

STRENGTHENED WITH $\mathrm{Al}_{2} \mathrm{O}_{3}$.

October 1975

University of Tennessee. Phd.

ORNL-NSF REPORTS

ORNL-NSF-EATC-10

Matti, C. S., Witherspoon, J. P., and Blaylock, B. G.

CYCLING OF MERCURY AND CADMIUM IN AN OLD FIELD ECOSYSTEM DURING ONE GROWING SEASON.

February 1975

University of Tennessee. MS

ORNL-TM REPORTS

ORNL-TM-1055

Blalock, T. V.

OPTIMIZATION OF SEMICONDUCTOR PREAMPLIFIERS FOR USE WITH SEMICONDUCTOR RADIATION DETECTORS :

February 1965

Univereity of Tennessee. Phd. 
ORNL-TM-1063

Child, H. R.

MAGNETIC STRUCTURE PROPERTIES OF SOME HEAVY RARE EARTH ALLOYS.

February 1965

University of Tennessee. Phd.

ORNL-TM-1066

Ricker, C. W., Hanauer, S. H., and Mann, E. R.

MEASUREMENT OF REACTOR FLUCTUATION SPECTRA AND SUBCRITIVAL REACTIVITY. Apri1 1965

University of Michigan. Phd.

URNL-TM-1075

Bundy, R. D.

VELOCITY AND MASS-DIFFUSION MEASUREMENTS FOR BEDS OF LARGE, UNIFORM-

DIAMETER SPHERES RANDOMLY PACKED IN A FULL-SCALE MODEL OF A PEBBLE-BED

NUCLEAR REACTOR CORE.

February 1966

University of Tennessee. MS

ORNL-TM- 1080

Carlsen, F. L., Jr.

EFFECTS OF PYROLYTIC-GRAPHITE STURCTURE ON DIFFUSION OF THORIUM.

June 1965

University of Tennessee. MS

ORNL-TM-1104

Huebrier, R. H., Arakawa, E. T., Hamm, R. N., and MacRae, R. A. OPTICAL CONSTANTS OF EVAPORATED METAL FILMS OF SILVER AND INDIUM.

Apri.1. 1.96 .5

Vanderbilt Untversity. MS

ORNL-TM-1105

Howe, H. J., Jr., and Ritch1e, R. H.

TRANSITION RADIATION AND LOW-ENERGY BREMSSTRAHLUNG.

August 1965

Vanderbilt University. MS

ORNL-TM-1107

Herickhoff, R. J., Arakawa, E. T., and Birkhoff, R. D.

CHARACTERISTIC ENERGY LOSS STUDIES OF ELECTRON-BOMBARDED Al, Cd, In, $\mathrm{Mg}$, AND $\mathrm{Zn}$ FOILS WITH VACUUM ULTRAVIOLET SPECTROSCOPY.

Apri1 1965

Vanderbilt University. Phd.

ORNL-TM-1124

Rodriquez, P.

HIGH-TEMPERATURE CREEP BEHAVIOR OF TYPE 304 STAINLESS STEEL IN ARGONOXYGEN ENVIRONMENT OF DIFFERENT OXYGEN PARTIAL PRESSURES.

May 1965

University of Tennessee. MS 
ORNL-TM- 1126

Hanson, W. F., Herickhoff, R. J., Arakawa, E. T., and Birkhoff, R. D. INVESTIGATION OF PLASMA RADIATION FROM ELECTRON BOMBARDED ALUMINUM FOILS AS A FUNCTION OF THE ANGLE OF OBSERVATION AND THE FOIL THICKNESS. June 1965

Vanderbilt University. MS

ORNL-TM-1129

Mathews, A. L., and Baes, C. F., Jr.

OXIDE CHEMISTRY AND THERMODYNAMICS OF MOLTEN LITHIUM FLUORIDE-BERYLLIUM

FLUORIDE BY EQUILIBRATION WITH GASEOUS WATER-HYDROGEN FLUORIDE MIXTURES. May 1965

University of Mississippi. Phd.

ORNL-TM-1153

Garber, F. W.

LOW ENERGY ELECTRON AND PROTON TRANSMISSION IN ALUMINUM AND SILVER.

August 1965

University of Tennessee. MS

ORNL-TM-1156

Courtney, J. C.

FAST-NEUTRON SCATTERING FROM SMALL CYLINDERS OF STEEL, ALUMINUM, AND GRAPHITE.

July 1965

Catholic University of America. Phd.

ORNL-TM-1164

Jelinek, T. M., Hamm, R. N., and Arakawa, E. T.

OPTICAL PROPERTIES OF VACUUM EVAPORATED FILMS OF CADMIUM, THALLIUM, AND ZINC IN THE VACUUM ULTRAVIOLET.

August 1965

Vanderbilt University. MS

ORNL-TM-1171

Mehta, E. K.

A NEW METHOD FOR THE EVALUATION OF NEUTRON EMISSION KERMA, KERMA EQUIVALENT, DOSE EQUIVALENT AND THE SPECTRUM BELOW 1 MEV FOR $(a, n)$ SOURCES, USING BONNER SPHERES.

July 1965

Univers1ty of Tennessee. MS

ORNL-TM-1184

Cain, V. R.

PROPAGATION OF NEUTRON WAVES THROUGH HETEROGENEOUS MULTIPLYING AND NONMULTIPLYING MEDIA.

August 1965

University of Florida. Phd. 
ORNL-TM-1185

Dodd, C. V.

A SOLUTION TO ELECTROMAGNETIC INDUCTION PROBLEMS.

August 1965

University of Tennessee. MS

ORNL-TM-1187

Kollie, T. G.

THE DEVELOPMENT OF A PULSE HEATING CALORIMETRIC TECHNIQUE FOR MEASURING

THE SPECIFIC HEAT OF ELECTRICAL CONDUCTORS AND ITS APPLICATION TO PURE

IRON FROM 100 TO $1400^{\circ} \mathrm{C}$.

August 1965

University of Tennessee. MS

ORNT-T.M- 11.88

Cook, J. L.

STUDIES OF THE THORIUM-URANIUM DICARBIDE PSEUDOBINARY SYSTEM IN THE PRESENCE OF EXCESS GRAPHITE.

September 1965

University of Tennessee. MS

ORNL-TM-1204

Silver, E. G.

MEASUREMENT OF THE NEUTRON DIFFUSION PARAMETERS IN ORDINARY ICE AS A

FUNCTION OF THE TEMPERATURE BY THE METHOD OF TIME-DEPENDENT NEUTRON

DIFFUSION .

September 1965

University of Tennessee. Phd.

ORNL-TM-1205

Coleman, W. $\Lambda$.

A DETERMINATION OF INTERMEDIATE-ENERGY NEUTRON ALBEDO DATA FOR CONCRETE USING MONTE CARLO.

September 1965

University of Tennessee. MS

ORNL-TM-1218

Gaedke, R. M.

SINGLE AND MULTI-NUCLEON TRANSFER REACTIONS INDUCED BY NITROGRN-14.

September 1965

University of South Carolina. Phd.

ORNL-TM-1229

McNamee, R. J.

RELATIONSHIP. BETWEEN HOLDUP AND FLOODING IN A PULSED, SIEVE PLATE

EXTRACT ION COLUMN.

March 1968

University of Tennessee. MS 
ORNL-TM-1236

Wichner, R. P.

DETERMINATION OF THE REYNOLDS STRESSES FOR AIR AND WATER PIPE FLOWS BY THE CONSTANT-CURRENT, LINEARIZED RESPONSE HOT-WIRE ANEMOMETÉR.

December 1965

University of Tennessee. Phd.

ORNL-TM-1262

Hadjiantoniou, A. D., Christophorou, L. G., and Hurst, G. S.

INTERACTION OF THERMAL ELECTRONS WITH POLARIZABLE AND POLAR MOLECULES. November 1965

Vanderbilt University. MS

ORNL-TM- 1283

Chester, C. V.

THE EFFECT OF IONIZING RADIATION ON COALESCENCE RATES IN LIQUID-LIQUID SYSTEMS.

December 1965

University of Tennessee. Phd.

ORNL-TM-1287

Parks, J. E., and Hurst, G. S.

STUDIES OF ELECTRON TRANSPORT IN GASES, USING TIME-OF-FLIGHT SWARM METHODS :

December 1965

Vanderbilt University. MS

ORNL-TM-1295

E1-Shishini, M. M., and Zobel, W.

TEMPERATURE DEPENDENCE OF THE RESPONSE OF LITHIUM DRIFTED GERMANIUM

DETECTORS TO GAMMA RAYS.

September 1966

University of Tennessee. MS

ORNT.-TM-1.31.1

Craven, C. W., Jr.

A STUDY OF THE WALL COOLING DUE TO TANGENTIAL INJECTION OF A FLUID

AROUND THE PERIPHERY OF AN AXIALLY SYMMETRIC JET.

May 1966

University of Tennessee. MS

ORNL-TM-1312, Vol. 3

Nelms, H. A.

STRUCTURAL ANAT.YSTS OF SHIPPING CASKS. VOLUME 3. EFFECTS OF JACKET PHYSICAL PROPERTIES AND CURVATURE ON PUNCTURE RESISTANCE.

June 1968

University of Tennessee. MS 
ORNL-TM-1312, Vol. 8

Evans, J. H.

STRUCTURAL ANALYSIS OF SHIPPING CASKS. VOLUME 8. EXPERIMENTAL STUDY

OF THE STRESS-STRAIN PROPERTIES OF LEAD UNDER SPECIFIED IMPACT CONDITIONS.

August 1970

University of Tennessee. MS

ORNL-TM-1312, Vo1. 9

Davis, F. C.

STRUCTURAL ANALYSIS OF SHIPPING CASKS. VOLUME 9. ENERGY ABSORPTION CAPABILITIES OF PLASTICALLY DEFORMED STRUTS UNDER SPECIFIED IMPACT T.NADING CONDITIONS.

February 1971

University of Tennessee. MS

ORNL-TM-1312, Vo1. 12

Cannon, D. D.

STRUCTURAL ANALYSIS OF SHIPPING CASKS. VOLUME 12. ENERGY ABSORPTION CHARACTERISTICS OF STAINLESS STEEL BOLTS UNDER IMPACT LOADING.

May 1972

University of Tennessee. MS

ORNL-TM-1323

Wright, W. C.

THE EFFECTS OF TIME DELAY SIMULATION METHODS UPON THE STABILITY AND TIME RESPONSE OF SIMULATED SYSTEMS.

December 1965

University of Tennessee. MS

ORNL-'I'M-1330, Rév.

Kress, 'I. S.

PARAMETERS OF ISOTHERMAL FISSION-PRODUCT DEPOSITION.

April 1966 (Originally issued December 1965)

University of Tennessee. MS

ORNL-TM- 1332

Lawrence, B. R.

NEUTRON DENSITY FLUCTUATIONS INDUCED BY HYDRAULIC NOISE IN A NUCL.FAR POẄER REACTOR.

December 1965

University of Tennessee. MS

ORNL-TM-1333

Niece, L. H.

INDEPENDENT YIELDS OF ${ }^{95} Z \mathrm{r}$ FROM THERMAL NEUTRON FISSION OF ${ }^{235} \mathrm{U}$ AND $2{ }^{3} \mathrm{U}$.

December 1965

University of Missouri. Phd. 


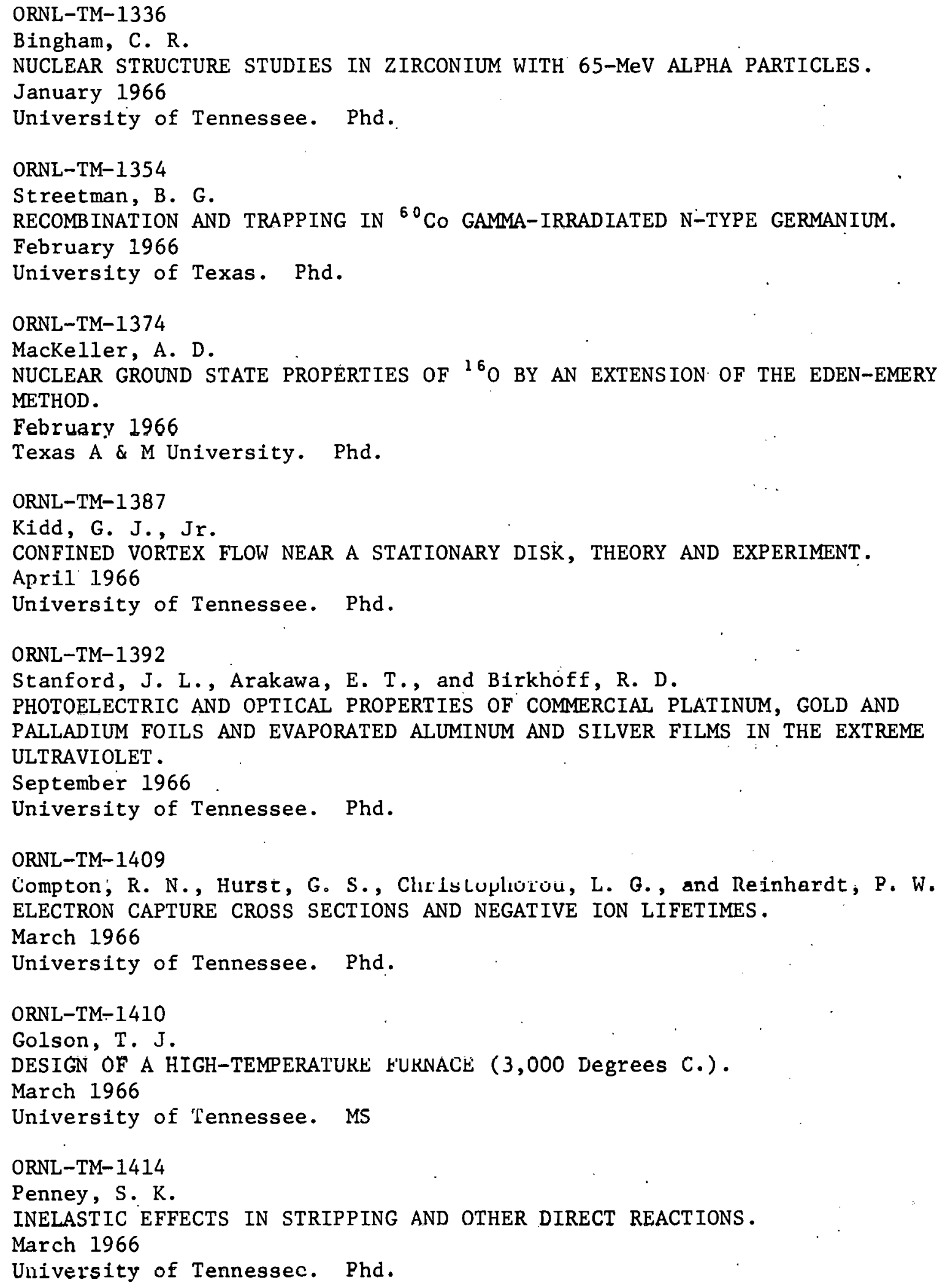




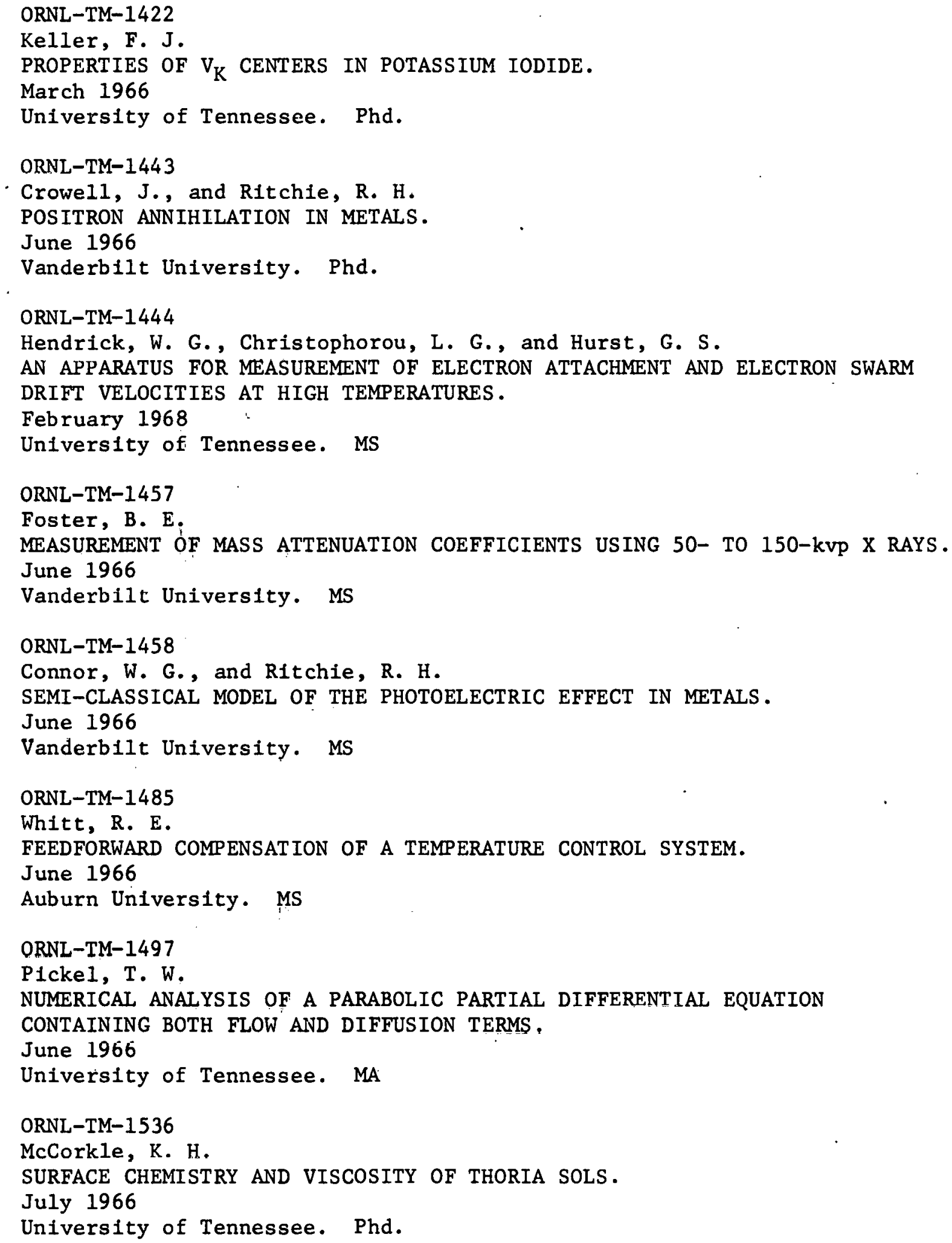


ORNL-TM-1540

Scott, C. D.

OXIDATION OF HYDROGEN AND CARBON MONOXIDE IN A HELIUM STREAM BY COPPER OXIDE. ANALYSIS OF COMBINED FILM AND PORE DIFFUSION WITH RAPID IRREVERSIBLE REACTION FOR TWO COMPONENTS IN A FIXED BED PROCESS.

August 1966

University of Tennessee. Phd.

ORNL-TM-1565

Pray, H. L., Birkhoff, R. D., Naka1, M. Y., and Ritchie, R. H. LOW ENERGY E'LECTRON STUDIES IN INDIUM AND MAGNESIUM.

September 1966

University of Tennessee. MS

ORNL-TM-1567

Couch, J. G.

NUCLEON TRANSFER IN ${ }^{14} \mathrm{~N}+{ }^{10} \mathrm{~B}$ AND ${ }^{14} \mathrm{~N}+{ }^{40} \mathrm{Ca}$ REACTIONS.

Sept.emher $196 \mathrm{~K}$

Texas A \& M University. Phd.

ORNL-TM-1571

Cram; L. S., Arakawa; E. T., Jones, G. E., and Birkhoff, R. D. . TRANSITION RADIATION AND LOW ENERGY B REMSSTRAHLUNG FROM SILVER AND ALUMINUM FOILS BOMBARDED BY GRAZING INCIDENCE ELECTRONS.

September 1966

Vanderbilt University. MS

ORNL-TM-1573

Gauster, W. B.

ULTRASONIC MEASUREMENT OF THE NON-LINEARITY PARAMETERS OF COPPER

SINGLE CRYSTALS.

September 1966

University of Tennessee. Phd.

ORNL-TM-1583

Tucker, R. P.

THE EFFECT OF NEUTRON IRRADIATION ON PLASTIC DEFORMATION IN NIOBIUM

SINGLE CRYSTALS.

November 1966

University of Tennessee. MS

ORNL-TM- 1585

Dittman, R., Cole, R. K., Sandhu, S., Waddeil, C. N.., and Dickens, J. K. THE ${ }^{19} \mathrm{~F}(\mathrm{p}, \alpha)^{16} 0$ AND ${ }^{19} \mathrm{~F}\left(\underline{\underline{p}},{ }^{3} \mathrm{He}\right)^{17} 0$ REACTIONS AT $30.5 \mathrm{MeV}$. Part of thesis. August 1966

University of Southern California. Phd. 
ORNL-TM-1602

Armistead, R. A., Jr.

TURBULENCE-INDUCED HEAT-TRANSFER FLUCTUATIONS IN PIPE FLOW OF WATER USING HOT-FILM WALL SENSORS.

April 1967

Carnegie-Mellon University. Phd:

ORNL-TM-1603

Jung, L.

EXPERIMENTAL VERIFICATION OF A GEOMETRICAL SHIELDING TRANSFORMATION. September 1966

University of Tennessee. MS

ORNL-TM-1649

Beatty, R. L.

PYROLYTIC CARBON DEPOSITED FROM PROPANE IN A FLUIDIZED BED.

January 1967

University of Tennessee. MS

ORNL-TM-1671

Snyders, L. S.

THE PHOTOELASTIC OBSERVATION OF ULTRASONIC WAVES IN A TRANSPARENT PLATE.

January 1967

University of Tennessee. MS

ORNL-TM-1681

Shalkh, M. U., Jacobs, D. G., and Parker, F. L.

A STUDY OF THE MOVEMENT OF RADIONUCLIDES THROUGH SATURATED POROUS MEDIA.

January 1,967

Vanderbilt University. MS

ORNL-TM-1683

Pitt, Jr., W. W.

VAPOR-LIQUID EQUILIBRIA OF THE BINARY SYSTEM URANIUM HEXAFLUORIDE -NIOBIUM PENTAFLUORIDE.

January 1967

University of Tennessee. MS

ORNL-TM-1685

ratterson, D. O., Roberts, L. D., Thumds, J. O., and Levey, R. P. GAMMA RAY OF 197 Au AND THE HYPERFINE STRUCTURE COUPLING OF $197 \mathrm{Au}$ IN THE ORDERED GOLD-MANGANESE ALLOYS.

January 1967

University of Tennessee. Phd.

ORNL-TM-1724

Dickson, H. W., Christophorou, L. G., and Compton, R. N.

ELECTRON CAPTURE BY HYDROGEN HALIDES AND THEIR DEUTERATED ANALOGUES. June 1967

University of Tennessee. MS 
ORNL-TM-1726

Kennedy, E. J.

A STUDY OF THE THEORETICAL AND PRACTICAL LIMITATIONS OF LOW-CURRENT AMPLIFICATION BY TRANSISTORIZED CURRENT-FEEDBACK DC ELECTROMETERS. Apri1 1967

University of Tennessee. Phd.

ORNL-TM-1753

Fricke, M. P.

INELASTIC SCATTERING OF 40-MeV POLARIZED PROTONS.

March 1967

University of Minnesota, Phd.

ORNL-TM-1776

Sutherland, J. C., Hamm, R. N., Stevenson, J. R., and Arakawa, E. T. OPTICAL PROPERTIES OF SODIUM IN THE VACUUM ULTRAVIOLET.

May 1967

Georgia Institute of Technology. Phd.

ORNL-TM-1777

Dalton, C. P., and Turner, J. E.

MEAN EXCITATION ENERGIES CALCULATED FROM STOPPING-POWER AND RANGE

DATA.

June 1967

Vanderb11t University. MS

ORNL-TM-1838

Anderson, J. W.

AN EVALUATION OF A FOAMED NONRIGID PLASTIC AS A SEAL.

July 1967

University of Tennessee. MS

ORNL-TM-1842

Dodd, C. V.

SOLUTIONS TO ELECTROMAGNETIC INDUCTION PROBLEMS.

June 1967

University of Tennessee. Phd.

ORNL-TM- 1850

Patterson, M. R., and Becker, R. L.

NON-ADIABATICITY CORRECTIONS TO THE BORN-OPPENHEIMER APPROXIMATION WITH CALCULATIONS FOR MESIC AND ELECTRONIC HYDROGEN MOLECULAR IONS.

August. 1967

University of Tennessee. Phd.

ORNL-TM-1860

Preedom, B. M.

SPECTROSCOPIC STUDY OF THE PROTON GROUND STATE CONFIGURATIONS IN THE ZIRCONIUM ISOTOPES.

June 1967

Untvers1ty of Tennessee. Phd. 


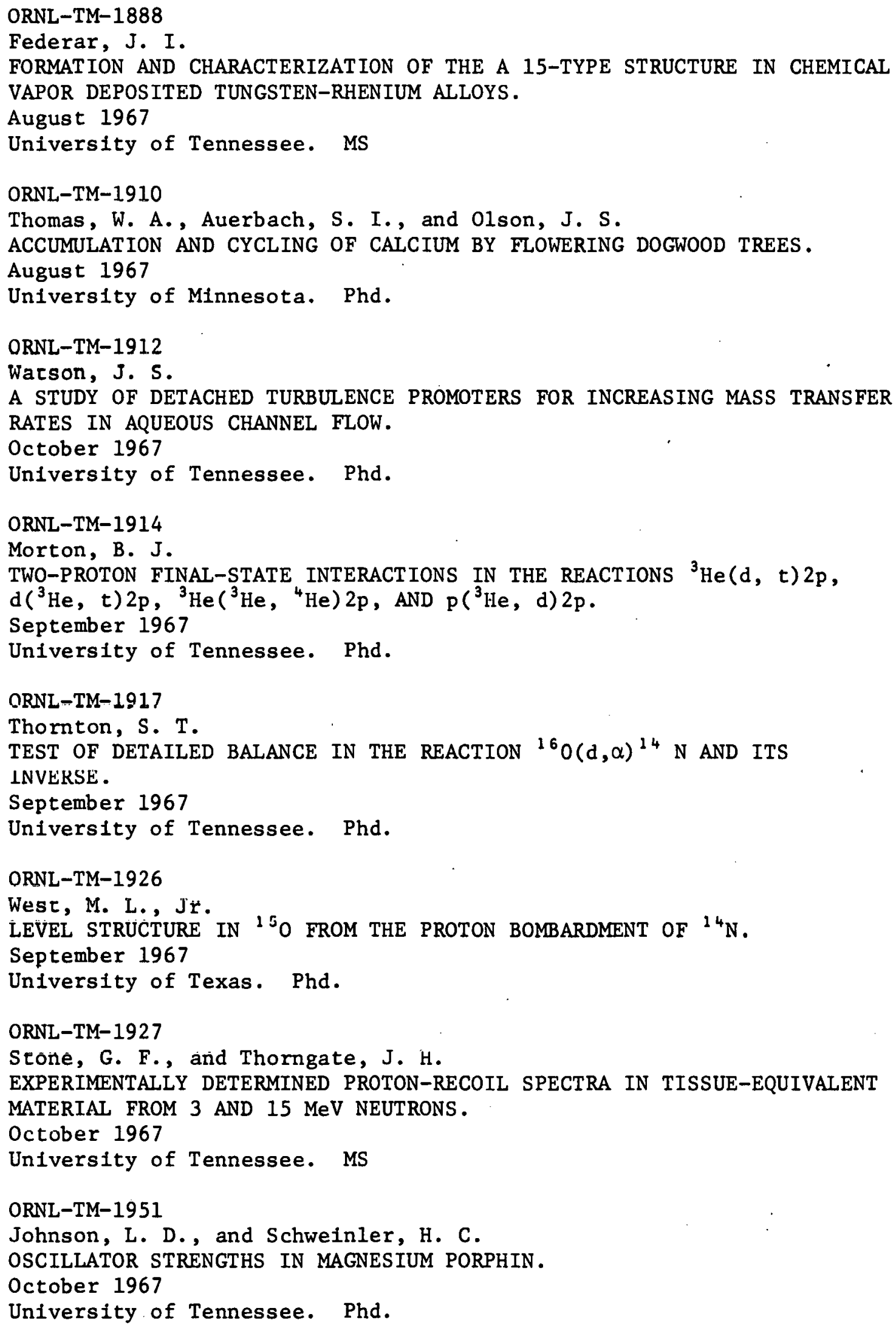


ORNL-TM-1952

Wright, H. A., and Snyder, W. S.

DIFFERENTIABILITY OF SET FUNCTIONS.

October 1967

University of Tennessee. Phd.

ORNL-TM-1988

Toburen, L. H., Nakai, M. Y., Langley, R..A.

THE MEASUREMENT OF HIGH-ENERGY CHARGE TRANSFER CROSS SECTIONS FOR

INCIDENT PROTONS AND ATOMIC HYDROGEN IN VARIOUS GASES AND THE K-, L-, AND M-AUGER, 1-COSTER-KRONIG, AND THE CONVERSION-ELECTRON SPECTRA OF PLATINIUM IN THE DECAY OF ${ }^{195} \mathrm{Au}$.

November 1967

Vanderbilt University. Phd.

ORNL-TM-2008

Marable, J. H.

A STIINY OF THF, THRFF,-RONY PRORT.F.M TN QIIANTIIM MF.SHANTS.S.

November 1967

University of Tennessee. Phd.

ORNL-TM-2014

King, R. T.

NUMERICAL METHODS FOR SINTERING BY VOLUME DIFFUSION.

January 1968

Carnegie-Mellon University. Phd.

ORNL-TM- 2015

Venard; J. T.

INVESTIGATION OF CERTAIN TERNARY SYSTEMS CONTAINING THORIUM AND

URANIUM.

January 1968

University of Tennessee. MS

ORNL-TM-2016

Weaver, S. C.

HELIUM GAS BUBBLE MIGRATION IN URANIUM MONONITRIDE IN A TEMPERATURE

GRADIENT .

December 1967

University of Tennessee. MS

ORNL-TM-2021, Vo1. I

DeVan, J. H.

EFFECT OF ALLOYING ADDITIONS ON CORROSION BEHAVIOR OF NICKEL-MOLYBDENUM

ALLOYS IN FUSED FLUORIDE MIXTURES. (Part of Thesis).

May 1969

University of Tennessee. MS 


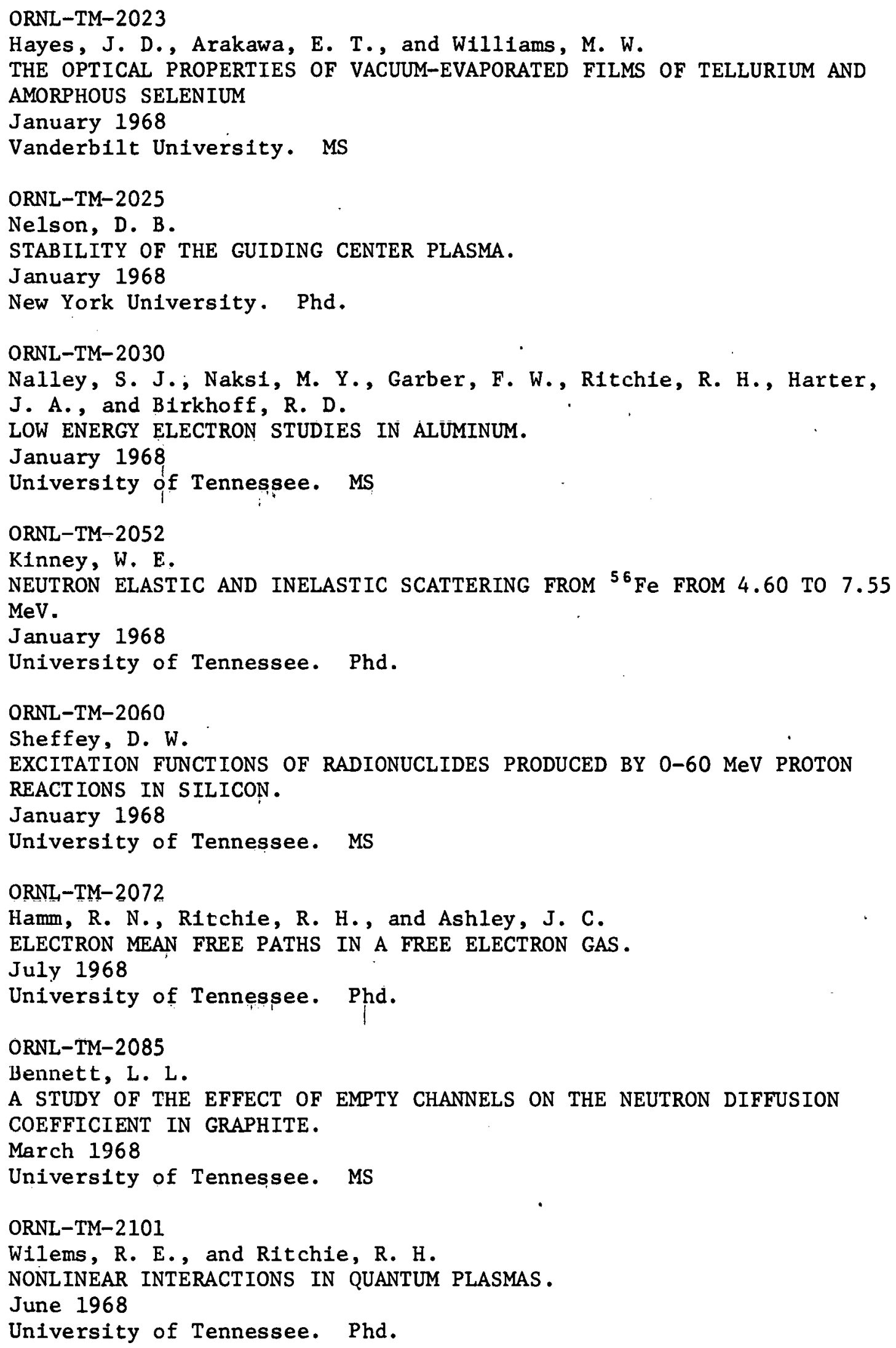


ORNL-TM-2102

Lomenick, T. F.

ACCELERATED DEFORMATION OF ROCK SALT AT ELEVATED TEMPERATURE AND

PRESSURE AND ITS IMPLICATIONS FOR HIGH LEVEL RADIOACTIVE WASTE DISPOSAL: March 1968

University of Tennessee. Phd.

ORNL-TM-2105

Fontana, M. H.

THE CHEMICAL EQUILIBRIA OF FISSION-PRODUCT-NUCLEAR FUEL MIXTURES: THE URANIUM OXYGEN AND THE URANIUM-OXYGEN STRONTIUM SYSTEM.

July 1968

Purdue UnIvers1ty. Phd.

ORNL-TM-2114

Riedinger, M. S., and Emerson, L. C.

DETERMINATION OF OPTICAL CONSTANTS OF PALLADIUM BY ELLIPSOMETRY.

February 1968

Vanderbilt University. MS

ORNL-TM-2115

Huggins, J. D.

STRUCTURAL ANALYSIS OF .SPACE FRAMES BY THE STIFFNESS METHOD.

May 1968

University of Tennessee. MS

ORNL-TM-2121

Milner, W. T.

COULOMB EXCITATION STUDIES OF ${ }^{104} \mathrm{Pd}, 106,10{ }^{10} \mathrm{Cd}, 182,184,186 \mathrm{~W}, 186$, $188,190,192$ Os, AND $192,194,196,198 \mathrm{Pt}$.

May 1968

University of Tennessee. Phd.

ORNL-TM-2122

Jones, J. K.

AN EXPERIMENTAL STUDY OF THE CRITICAL HEAT FLUX FOR LOW PRESSURE BOILING

WATER IN FORCED CONVECTION IN A VERTICAL SEVEN HEATER ROD BUNDLE.

April 1969

University of Tennessee. MS

ORNL-TM-2124

Brandon, C. A.

AN INVESTIGATION OF THE INTERACTION OF SOLID PARTICLES WITH FLUIDS IN TURBULENT PIPE FLOW.

September 1968

University of Tennessee. Phd.

ORNL-TM-2150

Mixon, W. R.

THE APPLICATION OF DETACHED TURBULENCE PROMOTERS TO A TUBULAR HYPER-

FILTRATION SYSTEM WITH DYNAMICALLY FORMED MEMBRANES.

March 1969

University of Tennessee. MS 
ORNL-TM-2151

Dress, $W$.

AN UPPER LIMIT FOR THE ELECTRIC DIPOLE MOMENT OF THE NEUTRON.

April 1968

Harvard University. Phd.

ORNL-TM-2156

Huebner, R. H., Compton, R. N., Christophorou, and Reinhardt, P. W. THRESHOLD ELECTRON EXCITATION AND TEMPORARY NEGATIVE ION SPECTRA OF MOLECULES.

June 1968

University of Tennessee. Phd.

ORNL-TM-2163

Clinton, S. D.

MASS TRANSFER OF WATER FROM SINGLE THORIA SOL DROPLETS FLUIDIZED IN

2-ETHYL-1-HEXANOL.

June 1968

University of Tennessee. MS

ORNL-TM-2165

Boughner, R. T.

THE DISCRETIZATION ERROR IN FINITE DIFFERENCE SOLUTIONS TO THE

LINEARIZED NAVIER-STOKES EQUATIONS FOR INCOMPRESSIBLE FLUID FLOW AT

LARGE REYNOLDS NUMBERS.

May 1968

University of Tennessee. MA

ORNL-TM-2166

Hamumons, C. E.

AN EXTRAPOLATION ALGORITHM FOR SPECIAL ORDINARY INITIAL VALUE PROBLEMS

BASED ON AN ELEMENTARY TRIGONOMETRIC MULTISTEP FORMULA.

June 1968

University of Tennessee. MA

ORNL $\cdots$ TM-2167

McKeever, J. W., and Schweinler, H. C.

JACOBI-GAUS QUADRATURE CALCULATIONS OF RYDBERG-KLEIN POTENTIAL ENERGY

CURVES FOR DIATOMIC MOLECULES AND SOLUTIONS OF THE ENSUING WAVE

EQUATIONS FOR SOME OF THEIR BOUND STATES.

May 1968

University of 'l'ennessee. MS

ORNL-TM-2195

Tangthieng, S.

TRANSIENT ANALYSIS OF TRANSISTORIZED LOGARITHMIC AMPLIFIERS.

July 1968

University of Tennessee. MS 
ORNL-TM-2206

Coleman, W. A:

THERMAL-NEUTRON FLUX GENERATION BY HIGH-ENERGY PROTONS.

July 1968

University of Tennessee. Phd.

ORNL-TM-2211

Sayer, R. 0 .

COULOMB EXCITATION OF ROTATIONS AND VIBRATIONS IN EVEN-EVEN RARE EARTH NUCLEI.

September 1968

University of Tennessee. Phd.

ORNL-TM-2214

Reedy, E. K.

A COMPUTER-AIDED STUDY OF A 600 MHz DECADE SCALING SYSTEM. August 1968

Univeroity of Tonnoeger. Phd.

ORNL-TM-2216

Blaunstein, R. P., and Christophorou, L. G.

ELECTRON ATTACHMENT TO ORGANIC MOLECULES.

July 1968

Untvers1ty of Tennessee. Phd.

ORNL-TM-2219

Abu-Zeid, M-E. M., Christophorou, L. G., and Carter, J. G. EMISSION AND DECAY OF ORGANIC LIQUIDS UNDER ELECTRON IMPACT.

February 1969

University of Tennessee. Phd.

ORNL-TM- 2222

Nelson, D. R.

DETERMINATION OF DIFFUSION COEFFICIENTS OF THERMAL ELECTRONS WITH A TIME-OF-FLIGHT SWARM EXPERIMENT.

November 1968

University of Tennessee. Phd.

ORNL-TM-2240

Vehse, R. C., and Arakawa, E. T.

OPTICAL AND PHOTOEMISSIVE PROPERTIES OF EVAPORATED FILMS OF PALLADIUM, NICKEL, AND COPPER IN THE VACUUM ULTRAVIOLET SPECTRAL REGION.

September 1968

University of Tennessee. Phd.

ORNL-TM- 2257

Christodoulides, A. A., and Christophorou, L. G.

SCATTERING OF THERMAL ELECTRONS BY POLAR MOLECULES.

August 1968

University of Tennessee. MS 
ORNL-TM-2260

Naff, W. T., Compton, R. N., Cooper, C. D., and Reinhardt, P. W. TRANSIENT NEGATIVE ION STATES IN SELECTED ALICYCLIC AND AROMATIC FLUOROCARBON MOLECULES.

November 1968

University of Georgia. MS

ORNL-TM-2261

Painter, L. R., Birkhoff, R. D., and Arakawa, E. T.

ELECTRONIC PROPERTIES OF LIQUID WATER IN THE VACUUM ULTRAVIOLET REGION. September 1968

University of Tennessee. MS

ORNL-TM-2264

Purcell, T. L.

RADIATION-INDUCED PARAMAGNETIC STATES OF SOME INTRINSIC DEFECTS IN ALKALI-GERMANATE GLASSES, POLYCRYSTALLINE $\mathrm{GeO}_{2}$, AND SINGLE CRYSTALS OF $\mathrm{GeO}_{2}, \mathrm{THO}_{2}$, AND $\mathrm{SnO}_{2}$.

August 1968 .

University of Tennessee., Phd.

ORNL-TM-2266

Siman-Tov, M.

EXTENDED SURFACES IN BOILING LIQUID.

October 1968

University of Cincinnati. MS

ORNL-TM-2272

Burnett, S. C.

PROMPT NEUTRON EMISSION IN THE MEDIUM-EXCITATION FISSION OF URANIUM.

October 1968

University of Tennessee. Phd.

ORNL-TM-2275

Mason, D. L.

PROTON-PROTON BREMSSTRAHLUNG MEASUREMENTS.

Ausust 1968

University of Florida. Phd.

ORNL-TM-2286

Peters, R. D.

ULTRASONIC MEASUREMENT OF THE TEMPERATURE DEPENDENCE OF COPPER

NONLINEARITY PARAMETERS.

April 1969

University of Tennessee. Phd.

ORNL-TM-2288

Rochelle, J. M.

SWITCHING TIME OF IDEALIZED REGENERATIVE CIRCUITS.

October 1968

University of Tennessee. MS 
ORNL-TM-2307

Clausing, R. E.

DESORPTION OF CARBON MONOXIDE FROM TUNGSTEN BY BOMBARDMENT WITH ELECTRONS.

April 1969

University of Virginia. DS

ORNL-TM-2308

Baird, J. K.

A SEARCH FOR A NEUTRON ELECTRIC DIPOLE MOMENT BY THE METHOD OF NEUTRON BEAM MAGNETIC RESONANCE.

February 1969

Harvard University. Phd.

ORNL-TM-2309

Callis, E. L.

ELECTRODISINTEGRATION OF ALUMINUM, IRON, NICKEL, AND COPPER AT 13.3

AND 1 h. $\cap$ GeV.

September 1968

University of Tennessee. MS

ORNL-TM- 2320

Snider, J. W.

EFFECTS OF GAS FLOW RATE ON THE MASS TRANSFER COEFFICIENT, MEASURED

ACROSS THE LIQUID-SOLID INTERFACE, IN A PACKED-BED CATALYTIC REACTOR.

February 1969

University of Tennessee. MS

ORNL-TM-2323

Paulus, T. J.

SYNTHESIS OF A DIRECTLY-COUPLED, WIDEBAND, DELAY-LINE BRIDGE WITH HIGH GAIN-STABILITY.

April 1969

University of Tennessee. MS

ORNL-TM-2339

Kernell, R. L.

THE 117 , 1i9 $\mathrm{Sn}(\mathrm{p}, \mathrm{n})^{117,119} \mathrm{Sb}$ REACTIONS NEAR $\mathrm{O}^{+}$ANALOGUE STATES. October 1968

University of Tennessee. Phd.

ORNL-TM-2381

Vondy, D. R.

THE DIRECT CRITICALITY SEARCH IN SOLUTION OF FINITE-DIFFERENCE

EIGENVALUE PROBLEMS.

March 1969

University of Tennessee. Phd. 
ORNL-TM-2406

Garber, F. W., Harter, J. A., Birkhoff, R. D., and Ritchie, R. H. LOW ENERGY ELECTRON BEAM STUDIES IN THIN METAL FILMS.

February 1969

University of Tennessee. Phd.

ORNL-TM-2426

Cates, M. R.

NUCLEAR STRUCTURE STUDIES IN THE MASS-90 REGION WITH THE $\left({ }^{3} \mathrm{He}, \mathrm{d}\right)$

REACT ION.

January 1969

Texas A \& M University. Phd.

ORNL-TM-2444

McAtee, W. J.

A THREE-DIMENSIONAL SCATTERED-LIGHT PHOTOELASTIC STRESSED CONCRETE

REACTOR VESSEL.

February 1969

University of Tennessee. MS

ORNL-TM-2472

Marusak, A. L.

MEASUREMENTS OF $(\mathrm{d}, \mathrm{n})$ REACTIONS ON ${ }^{58} \mathrm{Ni},{ }^{60} \mathrm{Ni},{ }^{62} \mathrm{Ni}$, AND ${ }^{64} \mathrm{Ni}$ AT 5 AND $10 \mathrm{MeV}$.

February 1970

University of Tennessee. Phd.

ORNL TM 2480

Tucker, R. P.

TRANSMISSION ELECTRON MICROSCOPY AND PLASTIC DEFORMATION IN NEUTRON-

IRRADIATED NIOBIUM.

March 1969

University of Tennessee. Phd.

ORNL-TM-2481

Gabriel, T. A., and Alsmiller, R. G. Jr.

PHOTONUCLEAR DISINTEGRATION AT HIGH $(<350 \mathrm{MeV})$ ENERGIES.

February 1969

University of Tennessee. Phd.

ORNL-TM-2507

Gilmore, F. C.

OPTICAL SPECTRA OF THE COBALT(II) ION AT SITES OF APPROXIMATELY

OCTAHEDRAL SYMMETRY IN SEVERAL CHLORIDE CRYSTALS.

July 1969

University of Tennessee. Phd.

ORNL-TM-2508

Cramer, S. N., Cain, V. R., Coveyou, R. R., Stevens, P. N., and

Straker, E. A.

THE USE OF KERNELS IN STUDYING NEUTRON TRANSPORT PROBLEMS.

June 1969

University of Tennessee. Phd. 
ORNL-TM-2514

Shankle, G. E.

THE ELECTRONIC STRUCTURE. OF THE NICKEL (II) ION IN DOPED LIC1 CRYSTALS. June 1969

University of Tennessee. Phd.

ORNL-TM-2546

Stockdale, J. A. D., Compton, R. N., and Reinhardt, P. W.

STUDIES OF NEGATIVE ION-MOLECULE REACTIONS IN THE ENERGY REGION FROM

ZERO TO THREE ELECTRON VOLTS.

May 1969

University of Tennessee. Phd.

ORNL-TM-2556

Nestor, C. W., Jr.

AN EFFECTIVE NUCLEON-NUCLEON INTERACTION FOR USE IN NUCLEAR HARTREE-FOCK CALCULATIONS.

July 1969

Vanderbilt University. Phd.

ORNL-TM-2565

Dodds, H. L., Jr.

EXPERIMENTAL DETERMINATION OF THE DIFFERENTIAL FAST NEUTRON FLUX IN THE HIGH FLUX ISOTOPE REACTOR US ING THRESHOLD DETECTORS.

May 1969

University of Tennessee. MS

ORNL-TM-2572

Brown; W. D.

THE DESIGN AND TESTING OF A COINCIDENCE ELECTROMAGNET FOR REACTOR

SAFETY SYSTEMS.

June 1969

University of Tennessee. MS

ORNL-TM-2584

Wagner, R. L:

A TECHNIQUE FOR MEASURING THE DIFFUSIVITY AND SOLUBILITY OF GASES IN METALS WITH APPLICATION TO NITROGEN IN TUNGSTEN.

July 1969

University of Tennessee. MS

ORNL-TM-2589

Love, J. C.

THE NICKEL-61 MÖSSBAUER EFFECT IN NICKEL-TRANSITION METAL ALLOYS AND NICKEL COMPOUNDS .

June 1969

Ohio State University. Phd. 
ORNL-TM-2612

Braundmeier, A. J., Jr.

EXPERIMENTAL INVESTIGATIONS OF SURFACE PLASMON RADIATION FROM

ALUMINUM.

December 1969

University. of Tennessee. MS

ORNL-TM-2613

Chaney, E. L., and Christophorou, L. G.

ELECTRON ATTACHMENT TO POLYATOMIC MOLECULES.

January 1970

University of Tennessee. Phd.

ORNL-TM-2614

Collins, P. M., Christophorou, L. G., and Carter, J. G.

LOW ENERGY ELECTRON ATTACHMENT TO POLYATOMIC MOLECULES AND NEGATIVE

ION LIFETIMES.

September 1970

University of Tennessee. Phd.

ORNL-TM-2615

Cowan, J. J., III, Arakawa, E. T., and Ritchie, R. H. THE SURFACE PLASMON RESONANCE EFFECT IN GRATING DIFFRACTION.

November 1969

University of Tennessee. Phd.

ORNL-TM-2617

Gesel1, T. F., and Arakawa, E. T.

PHOTOELECTRIC DETERMINATION OF ELECTRON ATTENUATION LENGTHS IN

MAGNESIUM AND ALUMINUM.

June 1971

University of Tennessee. Phd.

ORNL-TM-2618

Grissom, J. T., Compton, R. N., and Garrett, W. R.

ELECTRON IMPACT EXCITATION AND IONIZATION STUDIES OF THE RARE GASES.

March 1970

University of Tennessee. Phd.

ORNL-TM-2620

Nalley, S. J., Compton, R. N., Schweinler, H. C., and Reinhardt, H. W. COLLISIONAL IONIZATION ,BETWEEN CESIUM AND SELECTED MOLECULES.

April 1971

University of Tennessee. Phd.

ORNL-TM-2621

Vorà, R. B.

CALCULATION OF STOPPING POWER AT EXTREME RELATIVISTIC ENERGIES.

October 1970

University of Tennessee. MS 
ORNL-TM-2622

Whang, U. S., Call cott, T. A., and Arakawa, E. T. OPTICAL CONSTANTS OF CESIUM FOR PHOTONS OF ENERGY 5 TO $9.6 \mathrm{eV}$. March 1970

University of Tennessee. MS

ORNL-TM-2625

Gibson, J. R.

THE DESIGN AND EVALUATION OF A LABORATORY COLD ROLLING MILL.

October 1969

University of Tennessee. MS

ORNL-TM-2633

Luquire, J. W., III

THEORETICAL ANALYSES OF SELECTED ELECTROMAGNETIC INDUCTION PROBLEMS.

September 1969

University of Tennessee. Phd.

ORNL-TM-2649

Kollie, T. G.

CONTRIBUTIONS TO THE SPECIFIC HEAT CAPACITY OF NICKEL, IRON, AND THE ALLOY $\mathrm{Ni}_{3} \mathrm{Fe}$.

December 1969

University of Tennessee. Phd.

ORNL-TM-2654

Satterfield, M. M., Dyer, G. R., and McClain, W. J.

AN OVERLOAD CANCELLATION CIRCUIT FOR A CHARGE-SENSITIVE PREAMPLIFIER. Based on thesis "An Investigation of An Overload Cancellation Network for Charge-Sensitive Preamplifiers Used in Scintillation Spectrometry" July 1969

University of Tennessee. MS

ORNL-TM-2660

Sandberg, G. R., olson, J. S., and Clebsch, E. E. C.

INTERNAL DISTRIBUTION AND LOSS FROM ROOTS BY LEACHING OF CESIUM-137

INOCULATED INTO LIRIODENDRON TULIPFERA L. SEEDLINGS GROWN IN SAND

CULTURE.

September 1969

University of Tennessee. MS

ORNL-TM-2707

Stone, D. R., Thorngate, J. H., Crase, K. W., Brown, and Carver, D..W. THE DEVELOPMENT OF A SPECTROMETER AND THE MEASUREMENT OF THE NEUTRON SPECTRUM FROM THE HEALTH PHYSICS RESEARCH REACTOR BETWEEN $50 \mathrm{KeV}$ AND $450 \mathrm{KeV}$.

November 1969

University of Tennessee. MS 


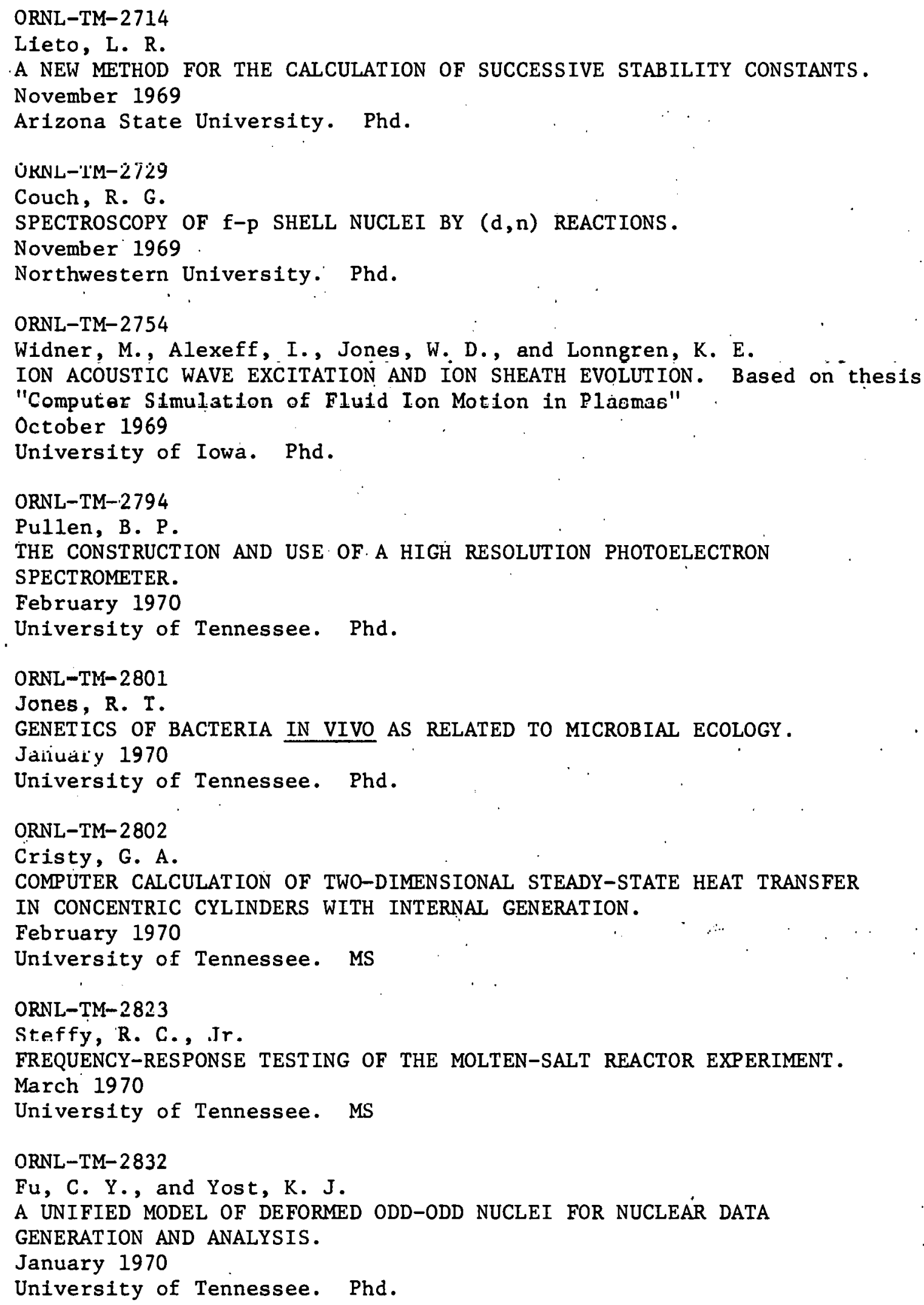


ORNL-TM-2847

McBrayer, J. F., Reichle, D. E., and Auerbach, S. I.

TROPHIC LEVEL DELINEATION OF FOREST SOIL MICROINVERTEBRATES.

February 1970

Purdue University. MS

ORNL-TM-2870

Pitt, W. W., Jr.

GRADIENT ELUTION CHROMATOGRAPHY OF URINARY CONSTITUENTS. MATHEMATICAL ANALYSIS OF THE KINETICS OF GRADIENT ELUTION CHROMATOGRAPHY.

April 1970

University of Tennessee. Phd.

ORNL-TM-2890

Burgart, C. E., and Stevens, P. N.

A GENERAL METHOD OF IMPORTANCE SAMPLING THE ANGLE OF SCATTERING IN MONTE CARLO CALCULATIONS.

Maicli 1970

University of Tennessee. Phd.

ORNL-TM-2991

Ritts, J. J., Solomito, M., and Stevens, P. N.

THE CALCULATION OF NEUTRON-INDUCED PHYSICAL DOSES IN HUMAN TISSUES.

May 1970

University of Tennessee. MS

ORNL-TM-3007

Ulrich, W. C.

AN EXTENDED HYDRAULIC MODEL OF THE MSRE CIRCULATING FUEL SYSTEM.

June 1970

University of Tennessee. MS

ORNL-TM- 3012

Moddeman, W. E.

AUGER SPECTROSCOPY OF SIMPLE GASEOUS MOLECULES.

September 1970

University of Tennessee. Phd.

ORNL-TM- 3017

Herdklotz, R. J., Jr.

THE THERMODYNAMIC PROPERTIES OF AQUEOUS HYDROCHLORIC ACID-SODIUM

CHLORIDE-MAGNESIUM CHLORIDE MIXTURES AS CALCULATED FROM ELECTROMOTIVE

FORCE MEASUREMENTS.

July 1970

University of Tennessee. Phd.

ORNL-TM-3092

Olsen, J. N.

FRACTIONAL FRINGE HCN LASER-INTERFEROME'TER. Based on thesis.

August 1970

Ohio State University. Phd. 
ORNL-TM-3109

Packan, N. H.

VOIDS IN NEUTRON IRRADIATED ALUMINUM.

January 1971

University of Missouri. Phd.

ORNL-TM- .31 .36

Dodds, H. L., Jr.

A NEW CALCULATIONAL METHOD FOR SPACE-ENERGY-ANGULAR DEPENDENT REACTOR KINETICS. January 1971

University of Tennessee. Phd.

ORNL-TM-3158

Braundmeler, A. J., Jr., Arakawa, E. T., and Williams, M. W.

RADIATIVE DECAY OF COULOMB-STIMULATED PLASMONS IN Al, Be, AND Mg.

October 1970

University of Tennessee. Phd.

ORNL-TM-3163

Christodoulides, A. A., and Christophorou, L. G.

ELECTRON ATTACHMENT TO POLYATOMIC MOLECULES

December 1970

University of Tennessee. Phd.

ORNL-TM-3168

Belt, B. D.

RADIATIVE CAPTURE OF DEUTERONS BY PROTONS AT 20 AND $30 \mathrm{MeV}$.

November 1970

University of Tennessee. Phd.

OKNL-'IM-3178

Ëads, B. G.

DESIGN AND APPLICATION OF A TIME-OPTIMUM CONTROLLER FOR A CLASS OF

NONLINEAR PROCESSES.

September 1971

Universicy of Virginia. MS

ORNL-TM-3198

Buckner, M. R.

OPTIMUM BINARY SIGNALS FOR FREQUENCY RESPONSE TESTING.

November 1970

Untversity of Tennessee. Phd.

ORNL-TM-3200

Cobb, W. R.

APPLICATION OF VARIATIONAL SYNTHESIS TO SOLUTIONS OF MULTIDIMENSIONAL NEUTRON TRANSPORT PROBLEMS.

Apri1 1971

Georgia Institute of Technology. Phd. 
ORNL-TM- 3201

Gwaltney, R. C.

AN ANALYSIS OF TORISPHERICAL SHELLS SUBJECTED TO CONCENTRATED LOADS. May 1971

University of Tennessee. Phd.

ORNL-TM- 3245

Ackerman, N. J., Jr.

AN ANALYTICAL AND EXPERIMENTAL INVESTIGATION OF THE NEUTRON ENERGY

EFFECTS ON REACTOR FLUCTUATION SPECTRA.

February 1971

University of Tennessee. Phd.

ORNL-TM- 3248

Stoddart, W. C. T.

TRANSIENT RESPONSE OF LINEAR ELASTIC STRUCTURES DETERMINED BY THE

MATRIX EXPONENTIAL METHOD.

January 1971

University of Tennessee. MS

ORNL-TM- 3252

Millard, J. K.

AN INVESTIGATION OF BROADBAND CURRENT PREAMPLIFICATION FOR OBTAINING

SIMULTANEOUS HIGH-RESOLUTION ENERGY AND TIME INFORMATION FROM NUCLEAR RADIATION DETECTORS .

March 1971

University of Tennessee. Phd.

ORNL-TM-3265

Klepper, O. H.

EXPERIMENTAL STUDY OF HEAT TRANSFER AND PRESSURE DROP FOR GAS FLOWING IN TUBES CONTAINING A SHORT TWISTED TAPE.

March 1971

University of Tennessee. MS

ORNL-TM- 3296

Sheppard, J. D.

SOME FACTORS AFFECTING THE PERFORMANCE ÓF HYPERFILTRATION MEMBRANES.

May 1971

University of Tennessee. Phd.

UKNL-TM-3307

Brooks, B. G., and Emerson, L. C.

THE TECHNIQUE OF ELLIPSOMETRY IN THE DETERMINATION OF THE OPTICAL CONSTANTS OF INDIUM AND TIN.

May 1971

University of Tennessee. MS 
ORNL-TM-3309

Martin, C. D., Jr.

THE DESIGN AND CONSTRUCTION OF A SMALL COMPUTER REAL-TIME EXECUTIVE

PROGRAM FOR PROCESS CONTROL AND DATA ACQUISITION.

July 1972

University of Tennessee. MS

ORNL-TM- 3311

Chang, S. I.

A SYSTEMATIC PROCEDURE FOR DETERMINING SYSTEM PARAMETERS BY PERFROMANCE INDEX MINIMIZATION.

May 1971

University of Tennessee. MS

ORNL-TM- 3325

Wilson, J. F.'

THE EFFECTS OF RADIATION ENERGY, DOSE LEVEL, AND THE ATOMIC NUMBER OF

THE IMMEDIATE ENVIRONMENT ON THE THERMALLY SIMULATED EXOELECTRON

EMISSION FROM BERYLLIUM OXIDE AND LITHIUM FLUORIDE.

May 1971

University of Tennessee. MS

ORNL-TM-3329

Poston, J. W.

NEUTRON DEPTH DOSE DISTRIBUTIONS IN HETEROGENEOUS PHANTOMS.

April 1971

Georgia Institute of Technology. Phd.

ORNL-TM-3346

Frank, M. L., and Blaylock, B. G.

EFFECTS OF ACUTE IONIZING RADIATION ON CARP (CYPRINUS CARPIO L.) E'MBRYOS.

May 1971

University of Tennessee. MS

ORNL-TM-3350

itiegler, J. 0 .

A STUDY OF THE FORMATION OF CREEP CAVITIES IN POWDER-METALLURGY TUNGSTEN.

September 1971

University of Tennessee. Phd.

ORNL-TM- 3372

Penland, J. R.

SPACE AND ENERGY DEPENDENCE OF REACTOR FLUCTUATION SPECTRA.

November 1972

University of Tennessee. Phd. 
ORNL-TM-3410

Naff, W. T.

ELECTRON ATTACHMENT AND EXCITATION PROCESSES IN SELECTED ORGANIC

MOLECULES .

May 1971

University of Georgia. Phd.

ORNL-TM-3413

Carr, K. R.

TESTING AND ANALYSIS OF THE THERMOELECTRICALLY INHOMOGENEOUS THERMOCOUPLE CIRCUIT.

September 1971

University of Tennessee. MS

ORNL-TM-3425

Chen, W. L., Shinpaugh, W. H., Hubbell, H. H., Jr., and Poston, J. W. DOSE DISTRIBUTIONS FROM NEUTRONS INCIDENT A TISSUE-EQUIVALENT PHANTOM. Tune 1971

University of Tennessee. MS

ORNL-TM-3438

Bartine, D. E., Alsmiller, R. G., Jr., Mynatt, F. R., Engle, Jr., W. W., and Barish, J.

LOW-ENERGY ELECTRON TRANSPORT BY THE METHOD OF DISCRETE ORDINATES.

August 1971

University of Missouri-Rolla. Phd.

ORNL-TM-3484

Rutkowski, R. W.

THE ${ }^{3} \mathrm{He}(\mathrm{d}, \mathrm{t}) 2 \mathrm{p}$ REACTION AT A CENTER-OF-MASS ENERGY OF $23.5 \mathrm{MeV}$.

August 1971

University of Tennessee. Phd.

ORNL-TM-3486

Harmon, H. D.

THE THIOCYANATE AND CHLORIDE COMPLEXES OF SOME TRIVALENT ACTINIDES.

July 1971

University of Tennessee. Phd.

ORNL-TM-3507

Macklin, C. E., and Witkamp, M.

DECOMPOSITION OF LEAF LITTER FROM TULIP POPLAR (LIRIODENDRON TULIPIFERA

L.) TREES DEFOLIATED WITH CACODYLIC. ACID.

January 1973

Emory University. MS

ORNL-TM- 3530

Solomito, E. (M.), Stevens, P. N., Straker, E. A., Burgart, C. E., and Cramer, S. N.

METHODS OF BIASING SECONDARY GAMMA-RAY PRODUCTION IN COUPLED NEUTRON

GAMMA-RAY MONTE CARLO CALCULATIONS.

December 1971

University of Tennessee. Phd. 
ORNL-TM-3564

Hanson, W. F., and Arakawa, E. T.

SOFT X-RAY STUDIES OF THE SATELLITES OF Na, Mg, A1, AND S1 AND THE OPTICAL PROPERTIES OF MgO AND MgF 2 .

October 1971

University of Tennessee. Phd.

ORNL-TM-3572

Crase, K. W., Becker, K., and Gammage, R. B.

PARAMETERS AFFECTING THE RADIATION-INDUCED THERMALLY STIMULATED

EXOELECTRON EMISSION FROM CERAMIC BERYLLIUM OXIDE.

November' 1971

University of Tennessee. Phd.

ORNL-TM-3605

Shorabi, M., and Becker, K.

SOME STUDIES ON THE APPLICATION OF TRACK ETCHING IN PERSUNNEL FAST NEUTRON DOSIMETRY.

December 1971

University of Tennessee. MS

ORNL-TM-3649

Whang, U. S., Arakawa, E. T., and Callcott, T. A.

OPTICAL PROPERTIES OF POTASSIUM RUBIDIUM, AND CESIUM IN THE VACUUM ULTRAVIOLET.

March 1972

University of Tennessee. Phd.

ORNL-TM-3665

Stowers, B. L., Birkhoff, R. D., and Arakawa, E. T.

OPTICAL PROPERTIES OF LIQUID $\mathrm{CCL}_{4}, \mathrm{C}_{6} \mathrm{H}_{14}, \mathrm{C}_{6} \mathrm{H}_{12}, \mathrm{C}_{6} \mathrm{H}_{10}, \mathrm{C}_{6} \mathrm{H}_{8}$, AND

$\mathrm{C}_{6} \mathrm{H}_{6}$ IN THE VACUUM ULTRAVIOLET.

March 1972

University of Tennessee. Phd.

ORNL-TM- 3718

Kress, T. S.

MASS TRANSFER BETWEEN SMALL BUBBLES AND LIQUIDS IN COCURRENT TURBULENT PIPELINE FLOW.

April 1972

University of Tennessee. Phd.

ORNL-TM- 3741

Garland, C. D.

ECONOMIC ALTERNATIVES AND POLICY IMPLICATIONS OF A STRATEGIC COMMODITY

RESERVE FOR NATIONAL SECURITY CONSIDERATIONS.

March 1972

University of Tennessee. Phd. 
ORNL-TM-3752

Elson, J. M., and Ritchie, R. H.

THE INTERACTION OF PHOTONS AT ROUGH DIELECTRIC SURFACES.

May 1972

University of Kentucky. Phd.

ORNL-TM-3771

Clinton, S. D.

MASS TRANSFER OF WATER FROM SINGLE AQUEOUS SOL DROPLETS FLUIDIZED IN A PARTIALLY MISCIBLE ALCOHOL.

July 1972

University of Tennessee. Phd.

ORNL-TM-3812

Crume, E. C., Jr.

NONLINEAR EVOLUTION OF FLUTE-LIKE PLASMA MICROINSTABILITIES.

May 1972

University of Tennessee. Phd.

ORNL-TM-3820

McGuire, G. E.

PHOTOELECTRON CHEMICAL SHIFTS IN INORGANIC COMPOUNDS .

July 1972

University of Tennessee. Phd.

ORNL-TM- 3839

McCorkle, D. L., and Christophorou, L. G.

LOW-ENERGY ELECTRON ATTACHMENT TO MOLECULES AT HIGH DENSITIES.

July 1972

University of Tennessee. Phd.

ORNL-TM-3858

Arnold, H. G.

PRESSURE VESSEL RELIABILITY AS A FUNCTION OF ALLOWABLE STRESS.

June 1972

University of Tennessee. MS

ORNL-TM- 3882

Guthrie, P. V., Jr.

AN X-RAY DIFFRACTION AND TRANSMISSION ELECTRON MICROSCOPY STUDY OF RECOVERY AND RECRYSTALLIZATION IN COLUMBIUM AND COLUMBIUM-40 VANADIUM.

August 1972

University of Cincinnati. Phd.

ORNL-TM- 3904

Pisanias, M. N., Christophorou, L. G., and Carter, J. G.

THRESHOLD-ELECTRON EXCITATION AND COMPOUND NEGATIVE ION FORMATION IN POLYATOMIC MOLECULES.

August 1972

University of Tennessee: Phd. 
ORNL-TM-3912

Mathies, J. B., Dunaway, P. B., Schnelder, G., and Auerbach, S. I. ANNUAL CONSUMPTION OF CESIUM-137 AND COBALT-60 LABELED PINE SEEDS

December 1972

Michigan State University. Phd.

ORNL-TM- 3918

Bartel1, D. M., Hurst, G. S., and Wagner, E. B.

TIME-DEPENDENT VACUUM ULTRAVIOLET EMISSION OF HELIUM.

September 1972

University of Kentucky. Phd.

ORNL-TM-3930

Tansil, J.E.

THE NICKEL-61 MÖ33BAUER EFFECT IN NICKEL-PALLADIUM ALLOYS.

August 1972

University of Tennessee. Phd.

ORNL-TM-3931

Monard, J. A.

MOSSBAUER STUDIES OF ELECTROSTATIC HYPERFINE INTERACTIONS IN ${ }^{2}{ }^{8} \mathrm{U}$, ${ }^{236} \mathrm{U}$, AND ${ }^{234} \mathrm{U}$.

August 1972

University of Tennessee. Phd.

ORNL-TM-3958

Lilitie, R. A.

INCORPORATION OF OUTER ITERATION TECHNIQUES INTO THE TASK ALGORITHM.

November 1972

University of 'l'ennessee. MS

ORNL-TM-3990

Hadjiantoniou, A. D., Christophorou, L. G., and Carter, J. G.

LONG-LIVED PARENT NEGATIVE IONS OF POLYATOMIC MOLECULES FORMED VIA NUCLEAR-EXCITED FESHBACH RESONANCES.

Ap 1111973

University of Tennessee. Phd.

ORNL-TM-3998

Blankenship, J. L., Jr.

GAMMA-RAY DAMAGE AND ANNEALING IN ULTRA-HIGH PURITY GERMANIUM.

January 1973

University of Tennsssee. Phd.

ORNL-TM-4036

Eissenberg, D. M.

AN INVESTIGATION OF THE VARIABLES AFFECTING STEAM CONDENSATION ON THE OUTSIDE OF A HORIZONTAL TUBE BUNDLE.

December 1972

University of Tennessee. Phd. 
ORNL-TM-4196

Childs, R. L., Engle, W. W., Jr., Robinson, J. C., and Mynatt, F. R. THE DEVELOPMENT AND APPLICAT ION OF. A DISCRETE ORDINATES ADJOINT DIFFERENCE METHOD FOR ONE-DIMENSIONAL SHIELD WEIGHT OPTIMIZATION. June 1973

University of Tennessee. MS

ORNL-TM-42.35

Ching, J., Goldstein, H., and Oblow, E. M.

APPLICAT ION OF A DISCRETE-ENERGY, D.ISCRETE-ORDINATES TECHNIQUE, TO THE STUDY OF NEUTRON TRANSPORT IN IRON.

December 1974

Columbia University. Phd.

ORNL-TM-4239

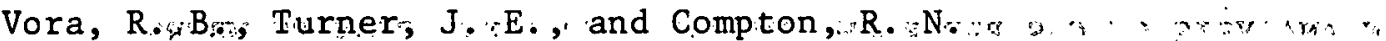
THEORY OF SINGLE 'ELECTRON EXCITATION AND TRANSFER IN NEUTRAE; ATOM-ATOM COLLIEIONE.

May 1973

University of Tennessee. Phd.

ORNL-TM-4290

Jolley; R. L. ,

CHLORINATION :EFFECTS ON ORGANIC CONSTITUENTS IN EFFLUENTS FROM DOMESTIC SANITARY SEWAGE TREATMENT PLANTS.

October 1973

University of Tennessee. Phd.

ORNL-TM-4323

Auxier, J:-A., Christian, D. J., Jones, T. D., Kerr, G. D., Perdue, P. T., Shinpaugh, W. H., and Thorngate, J. H. CONTRIBUTION OF NATURAL TERRESTRIAL SOURCES TO THE TOTAL RADIATION DOSE TO MAN:

Deptember 1973

Georgia Institute of Technology. Phd.

ORNL-TM-4368

Talmage, J. R., Jr., Hurst, G. S., Payne, M. G., and Wagner, E. B. TRANSPORT OF RESONANCE RADIATION IN ARGON.

October 1973

University of Kentucky. Phd.

ORNL-TM-4411

Garry,:-S. M., Stansbury, P. S., and Poston, J. W. MEASUREMENT OF .ABSORBED FRACTIONS -FOR PHOTON SOUREES DISTRIBUTED UNIFORMLY IN VARIOUS ORGANS OF A HETEROGENEOUS PHANTOM.

January 1974

University of Tennessee. MS 


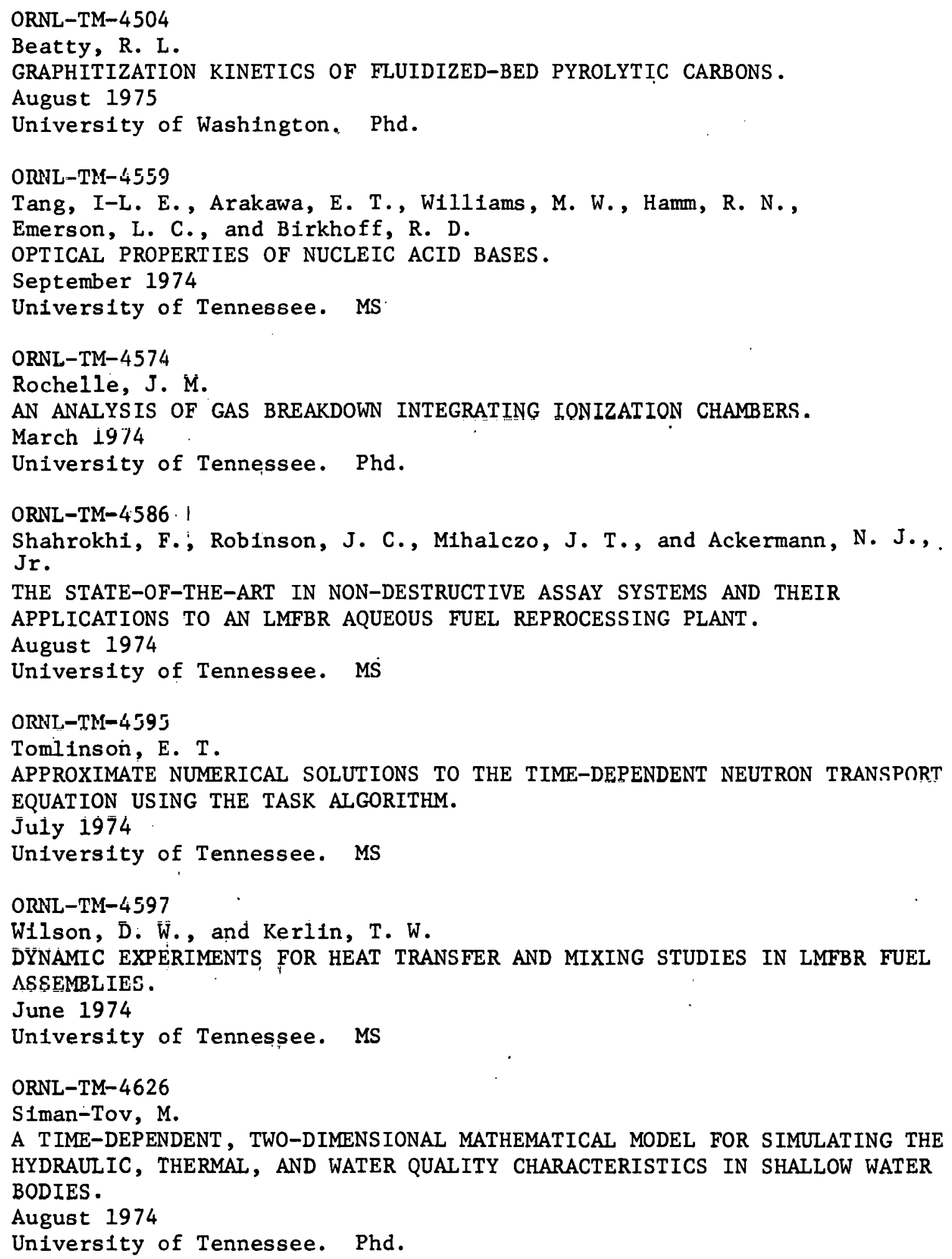


ORNL-TM-4661

McAlees, D. G.

ALPHA PARTICLE ENERGETICS AND NEUTRAL BEAM HEATING IN TOKAMAK

PLASMAS.

November 1974

University of Wisconsin. Phd.

ORNL-TM-4669

Carter, W. J., III

QUANTITATIVE X-RAY PHOTOELECTRON SPECTROSCOPY AND APPLICATIONS TO AIR POLLUTION.

September 1974

University of Tennessee. Phd.

ORNL-TM-4672

Cobble, J. A.

A SPECTROSCOPIC STUDY IN THE VACUUM ULTRAVIOLET OF A NEON PLASMA IN ELLMU.

September 1974

University of Tennessee. Phd.

ORNL-TM-4697

McNeely, J. R., Hurst, G. S., Wagner, E. B., Payne, M. G., and Jacobson, H. C.

TIME RESOLVED QUENCHING OF ARGON RESONANCE RADIATION BY NITROGEN

MOLECULES,

October 1974

University of Tennessee. MS

ORNL-TM-4702

Hsia, D. Y., and Chester, R. 0 .

A STUDY OF THE FISSION PRODUCT RELEASE FROM A BADLY DAMAGED WATERCOOLED REACTOR.

June 1974

Univeroity of Tennessee. MS

ORNL-TM-4758

Allen, J. W.

DEVELOPMENT AND APPLICATION OF A THREE-POINT INVERSE KINETICS ROD-DROP TECHNIQUE FOR SUBCRITICALITY DETERMINATION.

November 1975

University of Tenncosee. MS

ORNL-TM-4773

Juan, S. I., Arakawa, E. T., Williams, M. W., Inagaki, T., Hamm, R. N., Emerson, L. C., and Birkhoff, R. D.

OPTICAL PROPERTIES OF NUCLEIC ACID BASES IN THE SOFT X-RAY REGION.

February 1975

Univers1ty of Tennessee. MS 
ORNL-TM-4833

Neelavathi, V. N., and Ritchie, R. H.

THEORETICAL STUDIES OF SOME PLASMA EFFECTS IN CONDENSED MATTER.

March 1975

University of Tennessee. Phd.

ORNL-TM-4909

Deleanu, L., and Stockdale, J. A.

DISSOCIATIVE IONIZATION OF $\mathrm{O}_{2}$ AND $\mathrm{N}_{2}$ BY ELECTRON IMPACT.

May 1975

University of Tennessee. MS

ORNL-TM-4916

Mei, D. N. H., Stansbury, P. S., Warner, G. G., and Poston, J. W.

MEASUREMENTS OF ABSORBED FRACTIONS AS A FUNCTION OF SOURCE ORGAN

SIZE FOR SELECTED SOÜRE ORGANS IN A HETEROGENEOUS PHANTOM.

Auyus 1973

University of Tennessee. MS

ORNL-TM-5083

Kopp, M. K., and Borkowski, C. J.

POSITION-SENSITIVE PROPORTIONAL COUNTERS USING RESISTANCE--CAPACITANCE POSITION ENCODING.

December 1975

University of Tennessee. MS

\section{TID REPORTS}

The following theses were issued by the Technical Tnformation Centor of the Atomlc Energy Division. They were assigned TID numbers and distribution made in microfiche form. As the authors were on the staff and the work was done at the Laboratory, they are included.

TID-25453

Linsey, C. W. HIGH TEMPERATURE ENTHALPIES OF THE LEAD HALIDES: ENTHALPIES AND ENTROPIES OF FUSION.

June 1970

North Texas State University. Phd.

TID-25461

Twardzik, D. R.

A CHANGE IN THE ISOACCEPTING PATTERN OF tRNA/sup Tyr/ASSOCIATED WITH A SUPPRESSOR GENE IN DROSOPHILA.

April 1970

St. Bonaventure University. 'Phd. 
TID-25480

Whiting, F. L.

STUDIES OF THE SUPEROXIDE ION AND OTHER SOLUTE SPECIES IN MOLTEN FLUORIDES.

August 1970

University of Tennessee. Phd.

TID-25547

Hagenauer, R. G.

DECAY OF NEUTRON DEFICIENT NUCLIDES OF MASS 89.

March 1969

University of Tennessee. Phd.

TID-25630

Holmes, J. M.

THE IMPACT OF NUCLEAR ENERGY CENTERS ON THE ECONOMY OF PUERTO RICO. July 1970

Unlverslly of Teimessee. Thd.

TID-25720

Traylor, J. G.

LATTICE DYNAMICS OF RUTILE.

December 1970

University of Tennessee. Phd. 
UNIVERSITY INDEX

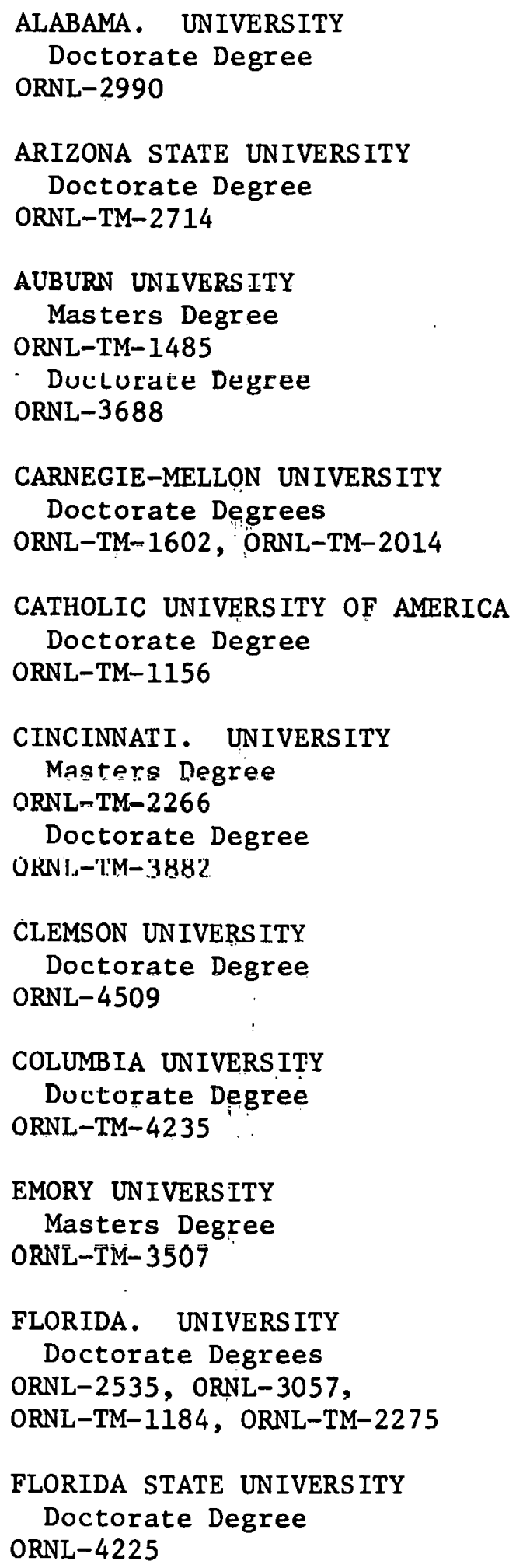

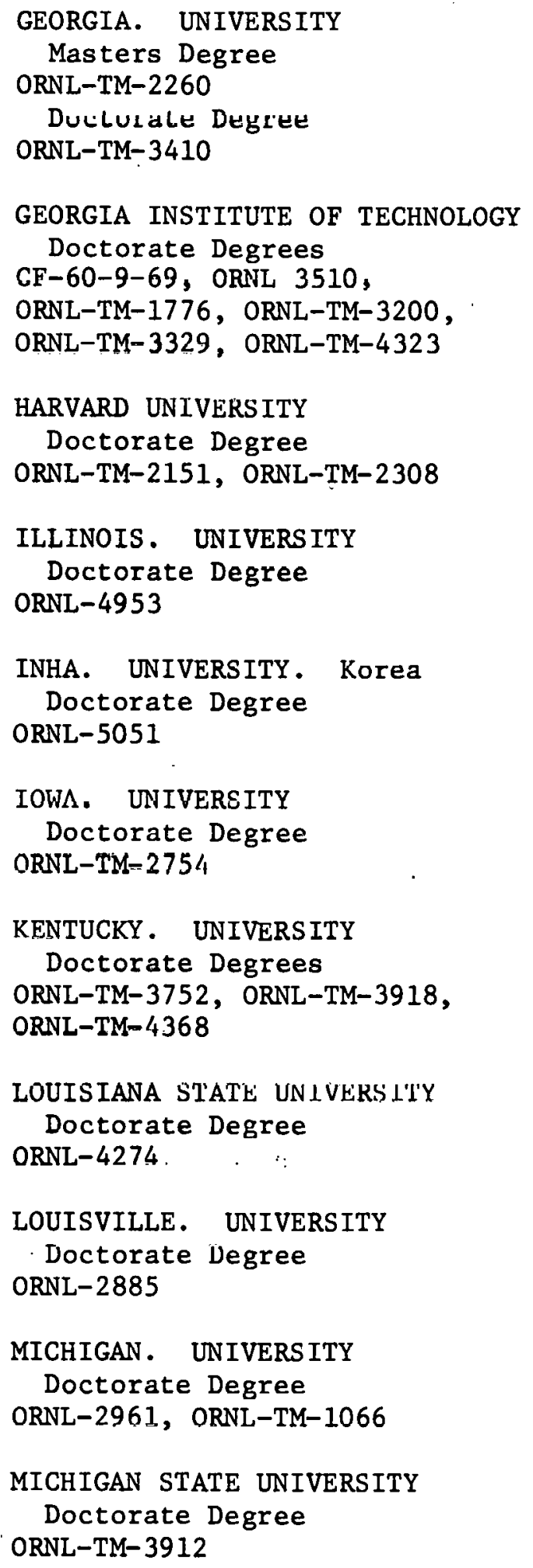


MINNESOTA. UNIVERSITY

Doctorate Degrees

ORNL-TM-1753, ORNL-TM-1910

MISSISSIPPI. UNIVERSITY

Doctorate Degree

ORNL-TM-1129

MISSOURI. UNIVERSITY

Doctorate Degrees

ORNL-TM-1333, ORNL-TM-3109

ORNL-TM- 3438

NEW YORK UNIVERSITY

Doctorate Degree

ORNL-TM-2025

NORTH GAROLINA STATF. INTVFRSTTY Doctorate Degree

ORNL-1910

NORTH TEXAS STATE UNIVERS ITY

Doctorate Degree

TID-25453

NORTHWESTERN UNIVERSITY

Doctorate Degrees

ORNL-4321, ORNL-TM-2729

OHIO STATE UNIVERSITY

Doctorate Degrees

ORNL-3743, ORNL-TM-2589

ORNL-TM-3092

OKLAHOMA. UNIVERSITY

Doctorate Degree

ORNL-3152

PENNSYLVANIA STATE UNIVERSITY

Doctorate Degree

ORNL-4808

PRINCETON UNIVERSITY

Doctorate Degree

ORNL-2659, ORNL-3914

PURDUE UNIVERSITY

Masters Degree

ORNL-TM-2847

Doctorate Degree

ORNL-T'M-210 5
RENSSELAER POLYTECHNIC INSTITUTE

Masters Degrees

ORNL-2571, ORNL-2582

SOUTH CAROLINA. UNIVERSITY

Doctorate Degree

ORNL-TM-1218

SOUTHERN CALIFORNIA. UNIVERSITY

Doctorate Degree

ORNL-TM- 1585

SOUTHERN ILLINOIS. UNIVERSITY

Doctorate Degree

ORNL-3682

ST. BONAVENTURE UNIVERSITY

Dnrttorate Degree

TID-25461

TENNESSEE. UNIVERSITY

Masters Degrees

CF-50-7-160, CF-51-7-135, ORNL-2372, ORNL-2524, ORNL-2534, ORNL-2549, ORNL-2635, ORNL-2669, ORNL-2674, ORNL-2701, ORNL-2742, ORNL-2804, ORNL-2860, ORNL-2862, ORNL-2946, ORNL-2957, ORNL-3091, ORNL-3098, ORNL-3109, ORNL-3141, ORNL-3292, ORNL-3294, ORNL-3296, ORNL-3390, ORNL-3438, ORNL-3473, ORNL-3494, ORNL-3507, ORNL-3551, ORNL-3563, ORNL-3616, ORNL-3657, ORNL-3678, ORNL-3685, ORNL-3751, ORNL-3764, ORNL-3986, ORNL-4008, ORNL-4114, ORNL-4142, ORNL-4193, ORNL-4310, ORNL-4339, ORNL-4391, ORNL-4504, ORNL-4957, ORNL-NSF-EATC-10, ORNL-TM-1075, ORNL-TM-1080, ORNL-TM-1124, ORNL-TM-1153, ORNL-TM-1171, ORNL-TM-1185, ORNL-TM-1187, ORNL-TM-1188, ORNL-TM-1205, ORNL-TM-1229, ORNL-TM-1295, ORNL-TM-1311, ORNL-TM-1312, Vo1. 3, ORNL-TM-1312, Vo1. 8, ORNL-TM-1312, Vol. 9 , ORNL-TM-1312, Vol. 12, ORNL-TM-1323, ORNL-TM-1330, Rev. ORNL-TM-1332, ORNL-TM-1410, ORNL-TM-1444, ORNL-TM-1497, ORNL-TM-1565, ORNL-TM-1583, 
TENNESSEE. UNIVERSITY - Cont.

ORNL-TM-1603, ORNL-TM-1649, ORNL-TM-1671, ORNL-TM-1683, ORNL-TM-1724, ORNL-TM-1838, ORNL-TM-1888, ORNL-TM-1927, ORNL-TM-2015, ORNL-TM-2016, ORNL-TM-2021, Vo1. I, ORNL-TM-2030, ORNL-TM-2060, ORNL-TM-2085, ORNL-TM-2115, ORNL-TM-2122, ORNL-TM-2150, ORNL-TM-2163, ORNL-TM-2165, ORNL-TM-2166, ORNL-TM-2167, ORNL-TM-2195, ORNL-TM-2257, ORNL-TM-2261, ORNL-TM-2288, ORNL-TM-2309, ORNL-TM-2320, ORNL-TM-2323, ORNL-TM-2444, ORNL-TM-2565, ORNL-TM-2572, ORNL-TM-2584, ORNL-TM-2612, ORNL-TM-2621, ORNL-TM-2622, ORNL-TM-2625, ORNL-TM-2654, ORNL-TM-2660, ORNL-TM-2707, ORNL-TM-2802, ORNL-TM-2823, ORNL-TM-2991, ORNL-TM-3007, ORNL-TM-3248, ORNL-TM-3265, ORNL-TM-3307, ORNL-TM-3309, ORNL-TM-3311, ORNL-TM-3325, ORNL-TM-3346, ORNL-TM-3413, ORNL-TM-3425, ORNL-TM-3605, ORNL-TM-3858, ORNL-TM-3958, ORNL-TM-4196, ORNL-TM-4411, ORNL=TM-4559, ORNL-TM-4586, ORNL-TM-4595, ORNL-TM-4597, ORNL-TM-4697, ORNL-TM-4702, ORNL-TM-4758, ORNL-TM-4773, ORNL-TM-4909, ORNL-TM-4916, ORNL-TM-5083,

\section{Doctorate Degrees}

CF-59-5-37, EDFB-IBP-72-13, EDFB-IBP-73-2, EDFB-IBP-73-8, E'DH'B-1BP-73-10, ORNL-2328, ORNL $=2670$, ORNL-2919, ORNL-2933, ORNL-2950, ORNL-3033, ORNL-3052, ORNL-3108, ORNL-3306, ORNL-3328, ORNL-3354, ORNL-3383, ORNL-3443, ORNL-3450, ORNL-3486, ORNL-3527, ORNL-3530, ORNL-3531, ORNL-3595, ORNL-3600, ORNL-3617, ORNL-3646, ORNL-3655, ORNL-3692, ORNL-3694, ORNL-3696, ORNL-3705, ORNL-3717, ORNL-3767, ORNL-3907, ORNL-3980, ORNL-4151, ORNL-4208, ORNL-4303,
ORNL-4318, ORNL-4445, ORNL-4452, ORNL-4458, ORNL-4479, ORNL-4561, ORNL-4568, ORNL-4580, ORNL-4610, ORNL-4612, ORNL-4686, ORNL-4826, ORNL-4893, ORNL-4987, ORNL-5088, QRNL-TM-1055, ORNL-TM-1.063, ORNL-TM-1204, ORNL-TM-1236, ORNL-TM-1283, ORNL-TM-1336, ORNL-TM-1387, ORNL-TM-1392, ORNL-TM-1409, ORNL-TM-1414, ORNL-TM-1.422, ORNL,-TM-1.536, ORNL-TM-1540, ORNL-TM-1573, ORNL-TM-1685, ORNL-TM-1726, ORNL - TM 1842, ORNL-TM-1850, ORNL-TM-1860, ORNL-TM-1912, ORNL-TM-1914, ORNL-TM-1917, ORNL-TM-1951, ORNL-TM-1952, ORNL-TM-2008, ORNL-TM-2052, ORNL-TM-2072, ORNL-TM-2101, ORNL-TM-2102, ORNL-TM-2121, ORNL-TM-2124, ORNL-TM-2156, ORNL-TM-2206, ORNL-TM-2211, ORNL-TM-2214, ORNL-TM-2216, ORNL-TM-2219, ORNL-TM-2222, ORNL-TM-2240, ORNL-TM-2264, ORNL-TM-2272, ORNL-TM-2286, ORNL-TM-2339, ORNL-TM-2381, ORNL-TM-2406, ORNL-TM-2472, ORNL-TM-2480, ORNL-T'M-2481, ORNL-TM-2507, ORNL-TM-2508, ORNL-TM-2514, ORNL-TM-2546, ORNL-TM-2613, ORNL-TM-2614, ORNL-TM-2615, ORNL-TM-2617, ORNL-TM-2618, ORNL-TM-2620, ORNL-TM-2633, ORNL-TM-2649, OLNL-TM-2794, ORNL-TM-2801, ORNL-TM-2832, ORNL-TM-2870 ORNL-TM-2890, ORNL-TM-3012, ORNL-TM-3017, ORNL-TM-3136, ORNL-TM-3158, ORNL-TM-3163, ORNL-TM-3168, ORNL-I'M-3198, ORNL-TM-3201, ORNL-TM-3245, ORNL-TM-3252, ORNL-TM-3296, ORNL-TM-3350, ORNL-TM-3372, ORNL-TM-3484, ORNL-TM-3486, ORNL-TM-3530, ORNL-TM-3564, ORNL-TM-3572, ORNL-TM-3649, ORNL-TM-3665, ORNL-TM-3718, ORNL-TM-3741, ORNL-TM-3771, ORNL-TM-3812, ORNL-TM-3820, ORNL-TM-3839, ORNL-TM-3904, 
TENNESSEE. UNIVERSITY - Cont.

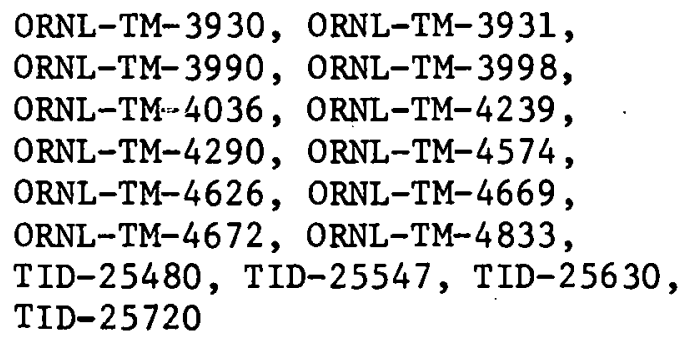

TEXAS. UNIVERSITY

Doctorate Degrees ORNL-3615, ORNL-3638,

ORNL-TM-1354, ORNL-TM-1926

TEXAS $A$ and $M$ UNIVERSITY

Doctorate Degrees

ORNL-TM-1374, ORNL-TM-1567, ORNL-TM-2426

\section{VANDERBILT UNIVERSITY}

Masters Degrees

ORNL-2013, ORNL-2136, ORNL-2137, ORNL-2158, ORNL-2298, ORNL-2352, ORNL-2419, ORNL-2521, ORNL-2529, ORNL-2533, ORNL-2569, ORNL-2724, ORNL-2730, ORNL-2732, ORNL-2755, ORNL-2775, ORNL-2783, ORNL-2807, ORNL-2887, ORNL-2912, ORNL-2969, ORNL-2970, ORNL-3002, ORNL-3027, ORNL-3114, ORNL-3115, ORNL-3172, ORNL-3346, ORNL-3422, ORNL-3463, ORNL-3468, ORNL-3469, ORNL-3484, ORNL-3485, ORNL-3635, ORNL-3702, ORNL-TM-1104, ORNL-TM-1105, ORNL-TM-1126, UKNL-TM-1164, ORNL-TM-1262, ORNL-TM-1287, ORNL-TM-1457, ORNL-TM-1458, ORNL-TM-1571, ORNL-TM-1681, ORNL-TM-1777, ORNL-TM-2023, ORNL-TM-2114

Doctorate Degrees

ORNL-2731, ORNL-TM-1107, ORNL-TM-1443, ORNL-TM-1988, ORNL-TM-2556

VIRGINIA. UNIVERSITY Masters Degree

ORNL-TM-3178

Doctorate Degree

ORNL-TM-2307
VIRGINIA POLYTECHNIC INSTITUTE Doctorate Degrees

ORNL-3873, ORNL-4144, ORNL 4700 , ORNL -4876

WASHINGTON. UNIVERSITY

Doctorate Degree

ORNL-TM-4504

WISCONSIN . UN IVERS ITY

Doctorate Degrees

ORNL-4850, ORNL-TM-4661 


ANATOMY
ORNL-3595
ASTRONOMY
ORNL-4953
BIOLOGY
IIRNI- 3957
ORNL-3682
TID-25461

BIOPHYSICS
ORNL-2533
ORNL-3115
ORNL-TM-1927
ORNL-TM-2991
ORNL-TM-3329
ORNL-TM-3425
ORNL-TM-3605
ORNL-TM- 4411
ORNL-TM- 4773
ORNL-TM- 4916

BUSINESS ADMINISTRATION

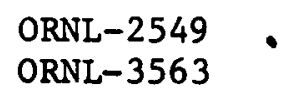

\author{
CHEMISTRY, ORGANIC \\ ORNL-3057
}

CHEMISTRY, PHYSICAL

$$
\begin{aligned}
& \text { CF-59-5-37 } \\
& \text { ORNL-2136 } \\
& \text { ORNL-2933 } \\
& \text { ORNL-3052 } \\
& \text { ORNL-3296 } \\
& \text { ORNL-TM-1129 } \\
& \text { ORNL-TM=1287 } \\
& \text { ORNL-TM-1683 } \\
& \text { ORNL-TM-1724 } \\
& \text { ORNL-TM-2260 } \\
& \text { ORNL-TM-2507 } \\
& \text { ORNL-TM-2514 } \\
& \text { ORNL-TM-2794 } \\
& \text { ORNL-TM-3012 } \\
& \text { ORNL-TM-3017 } \\
& \text { TID-25453 }
\end{aligned}
$$

$$
\begin{aligned}
& \text { CHËEISTRY, RADIATION } \\
& \text { ORNL-2970 } \\
& \text { ORNL-3002 } \\
& \text { ORNL-3346 }
\end{aligned}
$$

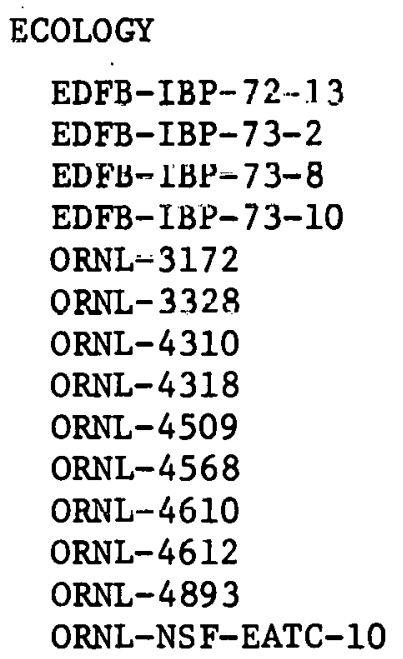




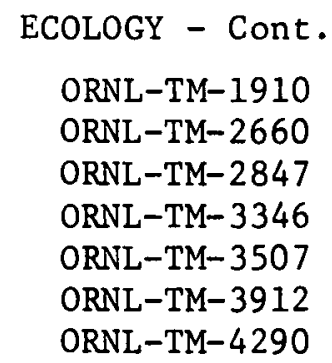

ENGINEERING, CHEMICAL

$$
\begin{aligned}
& \text { CF-50-7-160 } \\
& \text { ORNL-2742 } \\
& \text { ORNL-2885 } \\
& \text { ORNL-3109 } \\
& \text { ORNL-3292 } \\
& \text { ORNL-3494 } \\
& \text { ORNL-3527 } \\
& \text { ORNL-TM-1075 } \\
& \text { ORNL-TM-1229 } \\
& \text { ORNL-TM-1283 } \\
& \text { ORNL-TM-1485 } \\
& \text { ORNL-TM-1536 } \\
& \text { ORNL-TM-1540 } \\
& \text { ORNL-TM-1649 } \\
& \text { ORNL-TM-1912 } \\
& \text { ORNL-TM-2163 } \\
& \text { ORNL-TM-2320 } \\
& \text { ORNL-TM-2802 } \\
& \text { ORNL-TM-2870 } \\
& \text { ORNL-TM-3296 } \\
& \text { ORNL-TM-3718 } \\
& \text { ORNL-TM-3771 } \\
& \text { ORNL-TM-4036 } \\
& \text { ORNL-TM-4504 }
\end{aligned}
$$

ENGINEERING, CIVIL

$$
\begin{aligned}
& \text { ORNL-3473 } \\
& \text { ORNL-TM-2115 }
\end{aligned}
$$

ENGINEERING, ELECTRICAL

$$
\begin{aligned}
& \text { ORNL-2534 } \\
& \text { ORNL-2804 } \\
& \text { ORNL-2860 } \\
& \text { ORNL-3098 } \\
& \text { ORNL-3685 } \\
& \text { ORNL-TM-1055 } \\
& \text { ORNL-TM-1726 } \\
& \text { ORNL-TM-2195 } \\
& \text { ORNL-TM-2214 } \\
& \text { ORNL-TM-2288 } \\
& \text { ORNL-TM-2323 } \\
& \text { ORNL-TM-2572 } \\
& \text { ORNL-TM-2654 } \\
& \text { ORNL-TM-2754 } \\
& \text { ORNL-TM-3178 } \\
& \text { ORNL-TM-3252 } \\
& \text { ORNL-TM-3309 } \\
& \text { ORNL-TM- } 3413 \\
& \text { ORNL-TM-4574 } \\
& \text { ORNL-TM-5083 }
\end{aligned}
$$

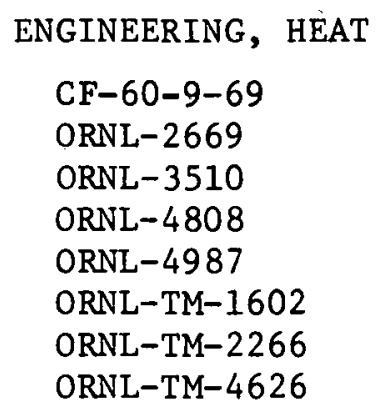

ENGINEERING, MATERIALS SCIENCE AND METALLURGY
CF-51-7-135
ORNL -2328
ORNL -2372
ORNL-2524
ORNL-2571
ORNL-2582 
ENGINEERING, MATERIALS SCIENCE AND METALLURGY - Cont.

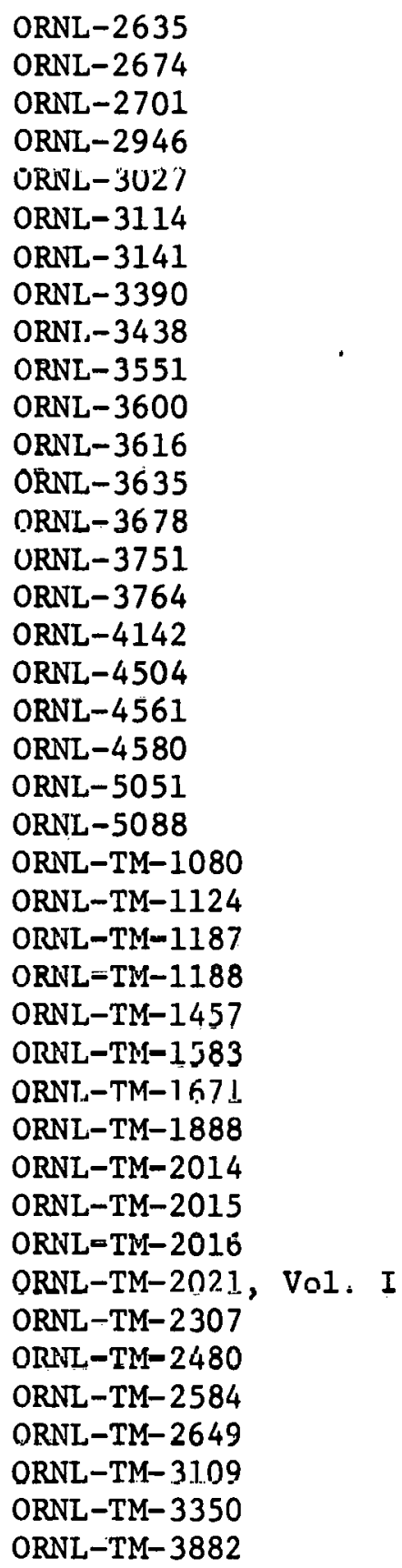

ENGINEERTNG, MECHAN ICAL

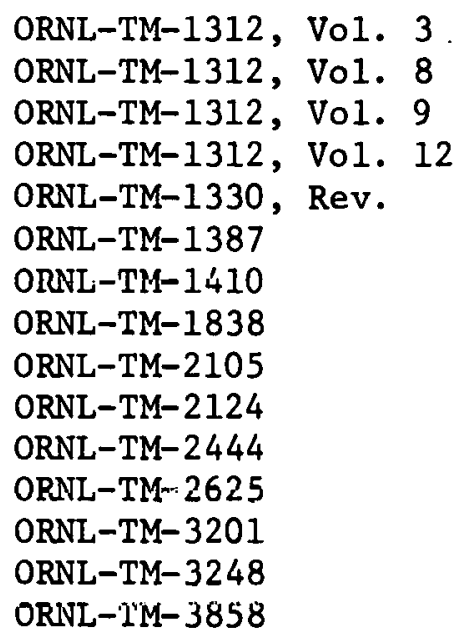

ENGINEERING, NUCLEAR
ORNL-3152
ORNL- 3507
ORNL-3657
ORNL-TM-1171
ORNL-TM-1205
ORNL-TM-1311
ORNL-TM-1323
ORNL-TM-2085
ORNL-TM-2206
ORNL-TM-2381
ORNL-TM-2508
URNL-TM-2565
ORNT:-TM-2823
ORNL-TM-28.32
ORNL-TM-2890
ORNL-TM-3007
ORNL-TM-3136
ORNL-TM-3198
ORNL-TM- 3200
ORNL-TM-3245
ORNL-TM- 3311
ORNL-TM- $33 \% 2$
ORNL-TM-3438
ORNL-TM-3530
ORNL-TM-3958
ORNL-TM-4196
ORNL-TM-4235
ORNL-TM $=4586$
ORNL-TM-459 7
ORNL-TM-4758
TID-25630 


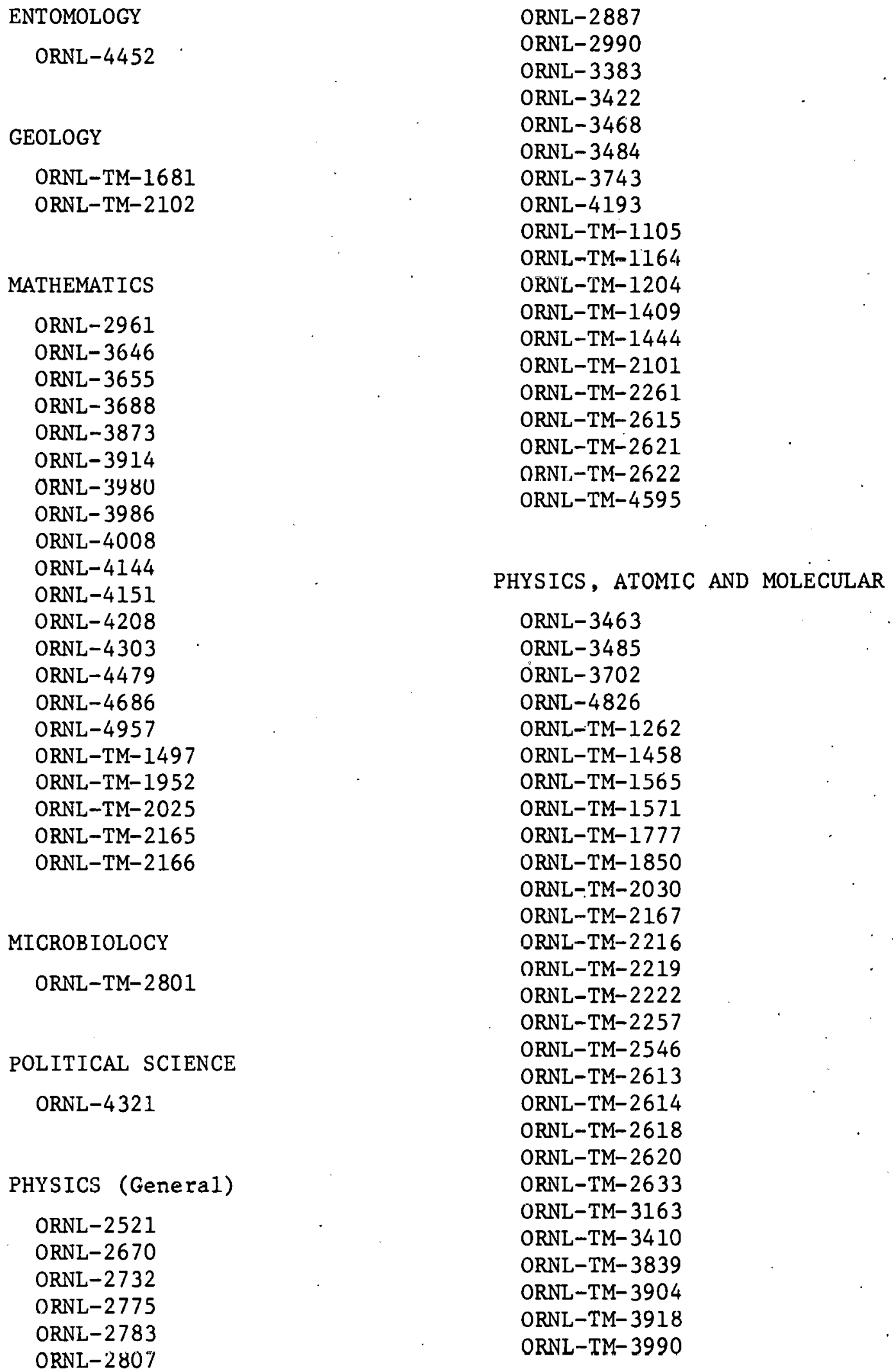


PHYSICS, ATOMIC AND MOLECULAR Cont.

ORNL-TM-4239

ORNL-TM-4368

ORNL-TM-4697

ORNL-TM-4909

PHYSICS, ELECTRONICS AND ELECTRICITY

ORNL-3091

ORNL-TM-1185

ORNL-TM-1842

PHYSICS, NUCLEAR

ORNL-2013

ORNL-2158

ORNL -2298

ORNL-2535

ORNL-2659

ORNL-2724

ORNL -2730

ORNL-2731

ORNL-2912

ORNL-2919

ORNL- 2950

ORNL-2969

ORNL-3033

ORNL-3306

ORNL-3450

ORNL-3469

ORNL-3486

ORNL-3615

URNL- 3638

ORNL-3692

ORNL-3696

ORNL-3717

ORNL-4114

ORNL -4274

URNL-4339

ORNL-TM-1104

ORNL-TM-1107

ORNL-TM-1156

ORNL-TM-1184

ORNL-TM-1218

ORNL-TM-1295

ORNL-TM-1332

ORNL-TM-1333
ORNL-TM-1336

ORNL-TM-1374

ORNL-TM-1414

ORNL-TM-1567

ORNL-TM-1585

ORNL-TM-1603

ORNL-TM-1753

ORNL-TM-1860

ORNL-TM-1914

ORNL-TM-1917

ORNL-TM-1926

ORNL-TM-1951

ORNL-TM-2008

ORNL-TM-2052

ORNL-TM-2060

ORNL-TM-2121

ORNL-TM-2151

ORNL-TM-2156

ORNL-TM-2211

ORNL-TM-2272

ORNL-TM-2275

ORNL-TM-2308

ORNL-TM-2309

ORNL-TM-2339

ORNL-TM-2426

ORNL-TM-2472

ORNL-TM- 2481

ORNL-TM-2556

ORNL-TM-2707

ORNL-TM-2729

ORNL-TM-3168

ORNL-TM-3484

ORNL-TM-3931

TID-25547

PHYSICS, PLASMA

ORNL-TM-1126

ORNL TM- 3092

ORNL-TM-3812

ORNL-TM-4,661

ORNL-TM-4672

PHYSICS, RADIATION

ORNL-1910

ORNL-2137

ORNL-2352

ORNL-2755

ORNL-TM-2406 


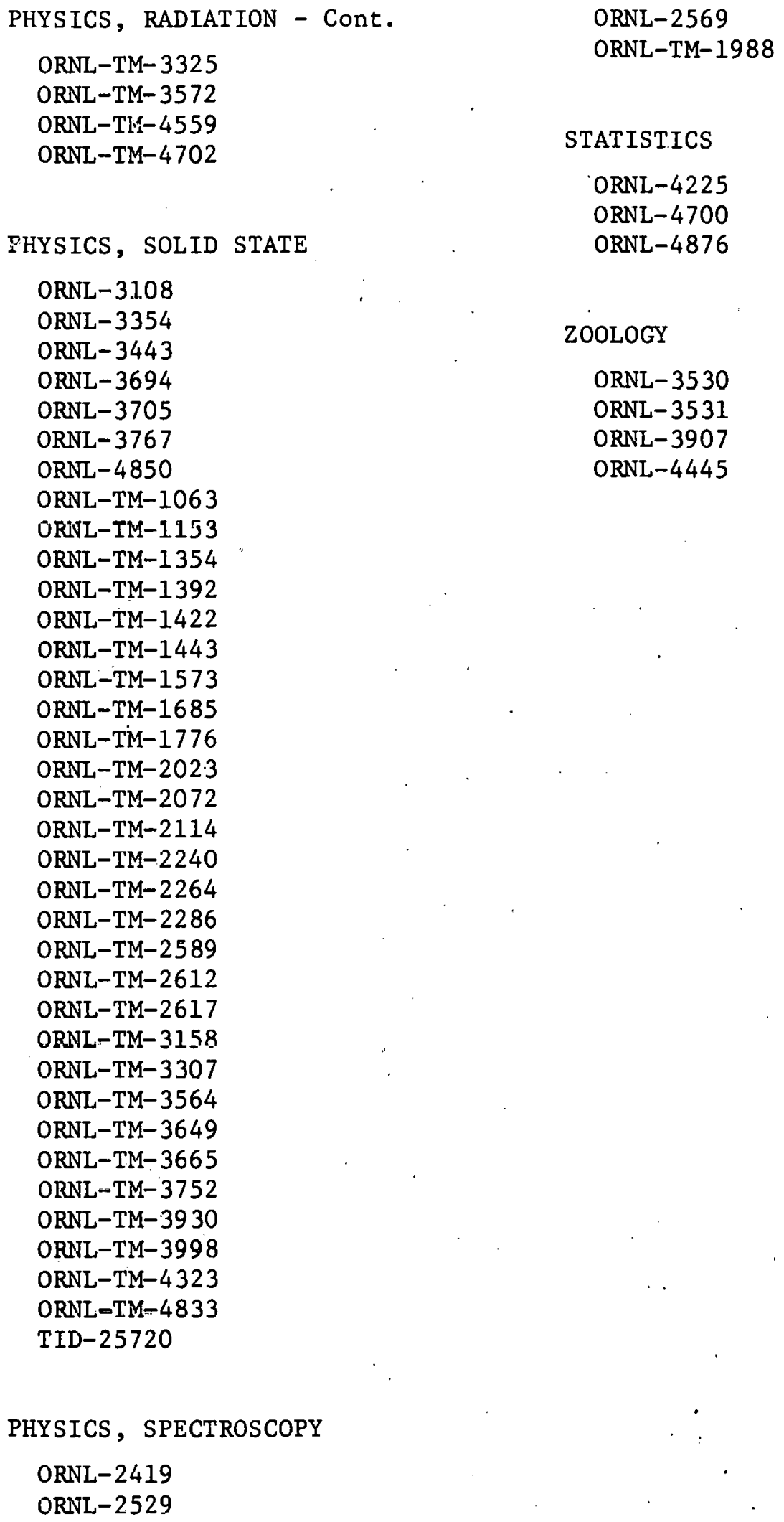

\section{ZOOLOGY}

ORNL- 3530

ORNL- 3531

ORNL-3907

ORNL -4445 
AUTHOR INDEX

A

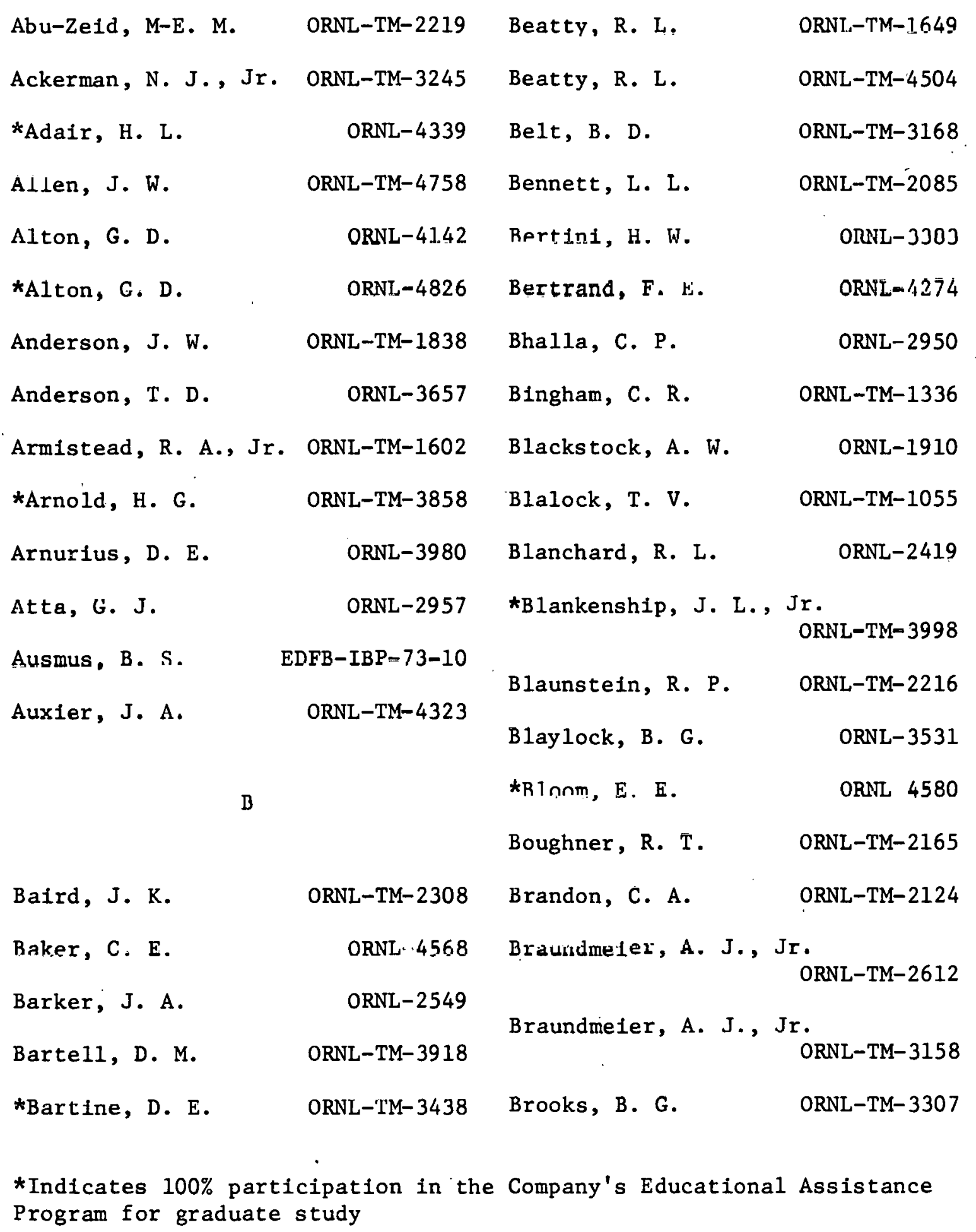




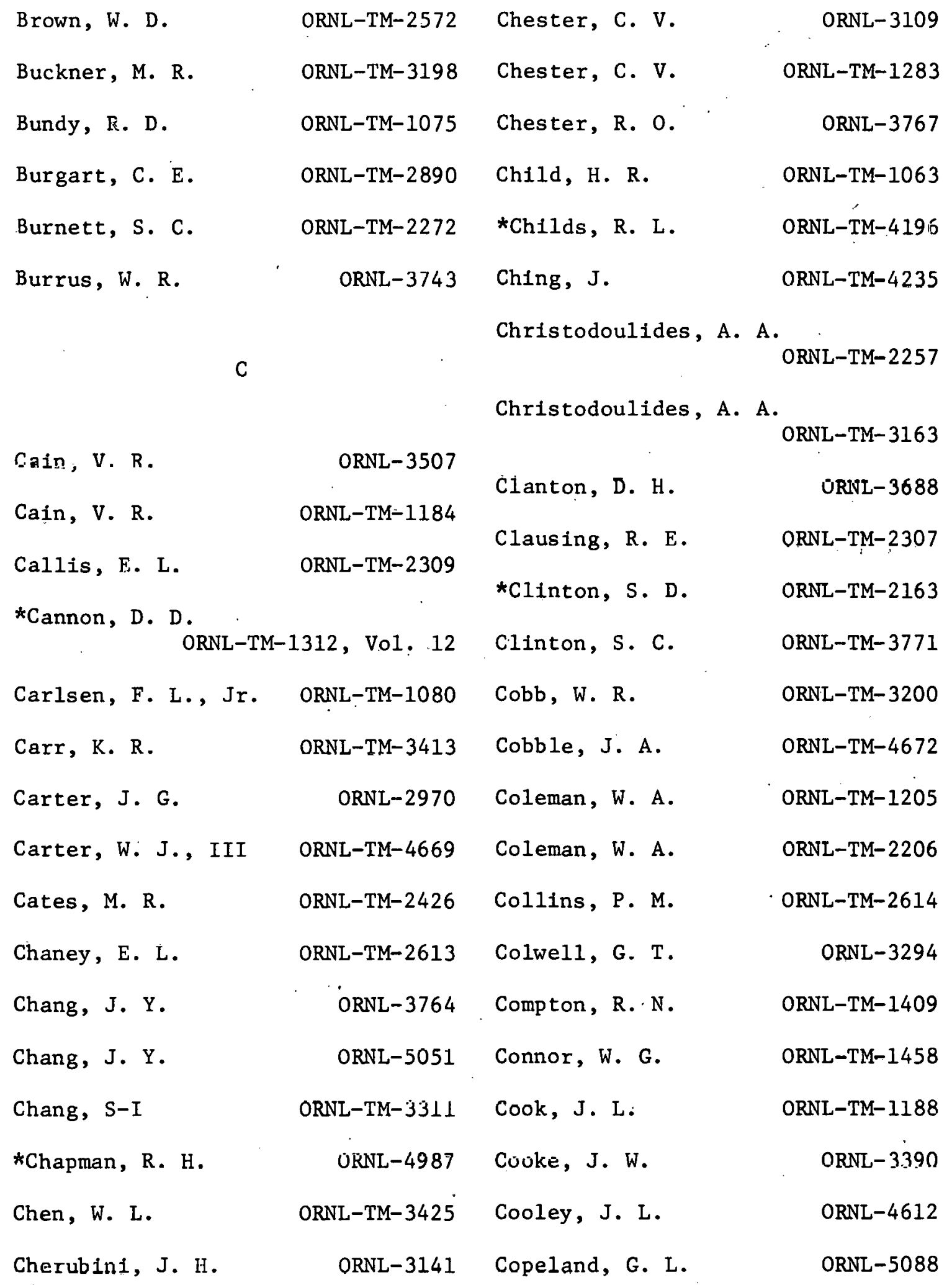

*Indicates $100 \%$ participation in the Company's Educational Assistance Program for graduate study 


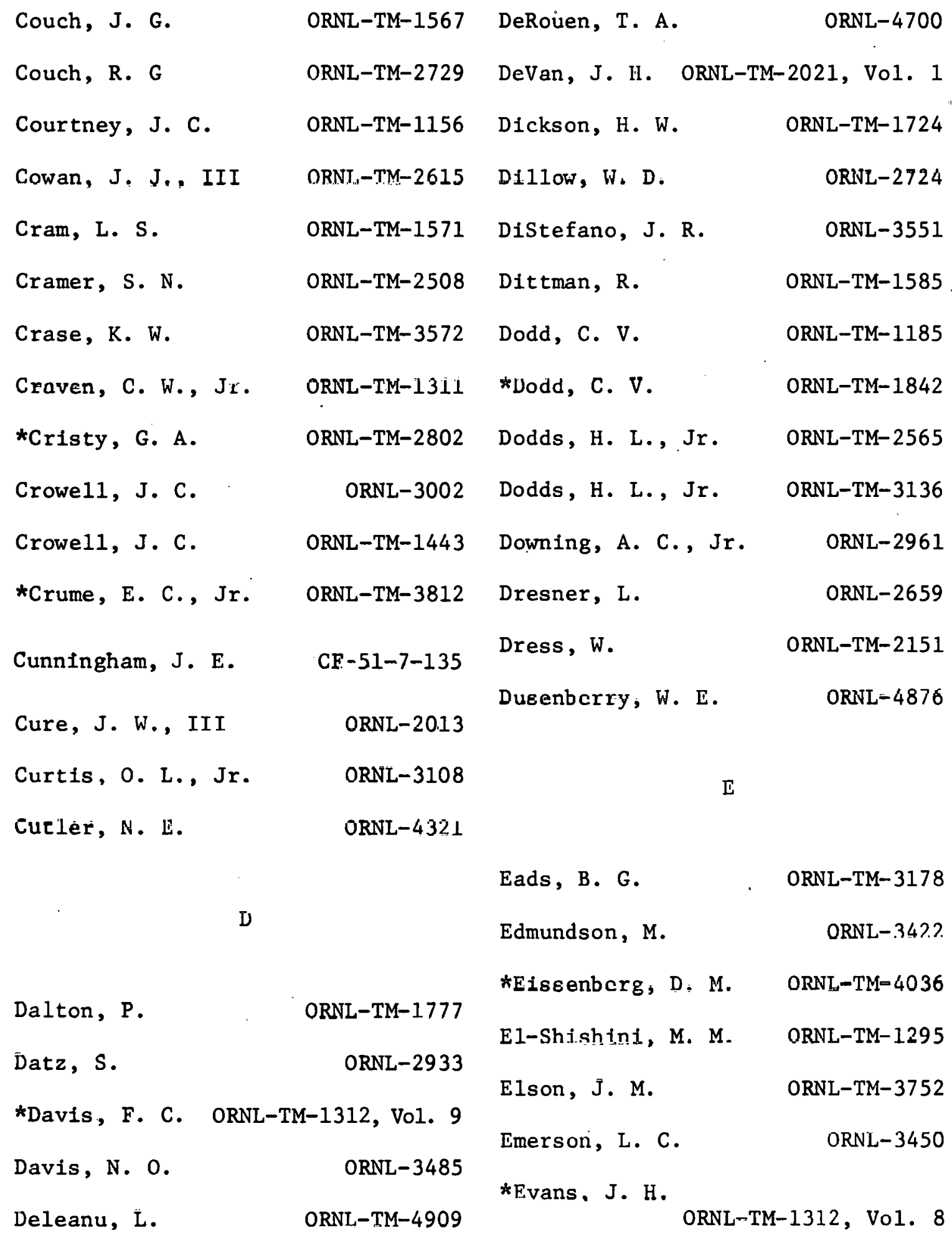

*Indicates $100 \%$ participation in the Company's Educational Assistance Program for graduate study 


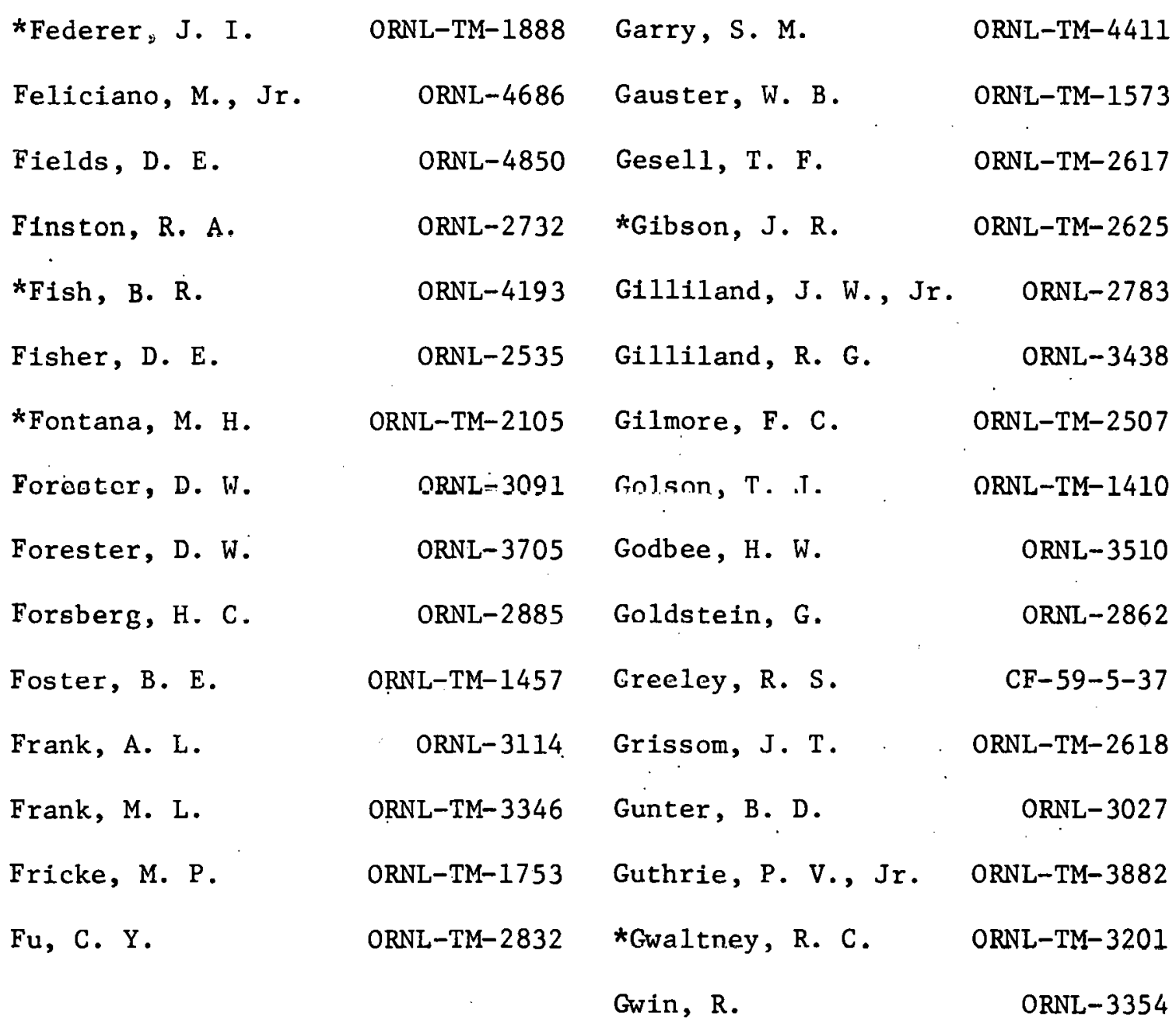

G

$\mathrm{H}$

Gabriel, T. A. ORNL-TM-2481

$\begin{array}{lll}\text { Gaedke, R. M. ORNL-TM-1218 Haas, P. A. ORNL-3527 } & \text { O. }\end{array}$

Garber, F. W. ORNL-TM-1153 Hadjiantoniou, A. D. ORNL-TM-1262

Garber, F. W. ORNL-TM-2406 Hadjiantoniou, A. D. ORNL-TM-3990

Garland, C. D. ORNL-TM-3741 Hagenauer, R. C. TID-25547

*Indicates $100 \%$ participation in the Company's, Educational Assistance Program for graduate study 


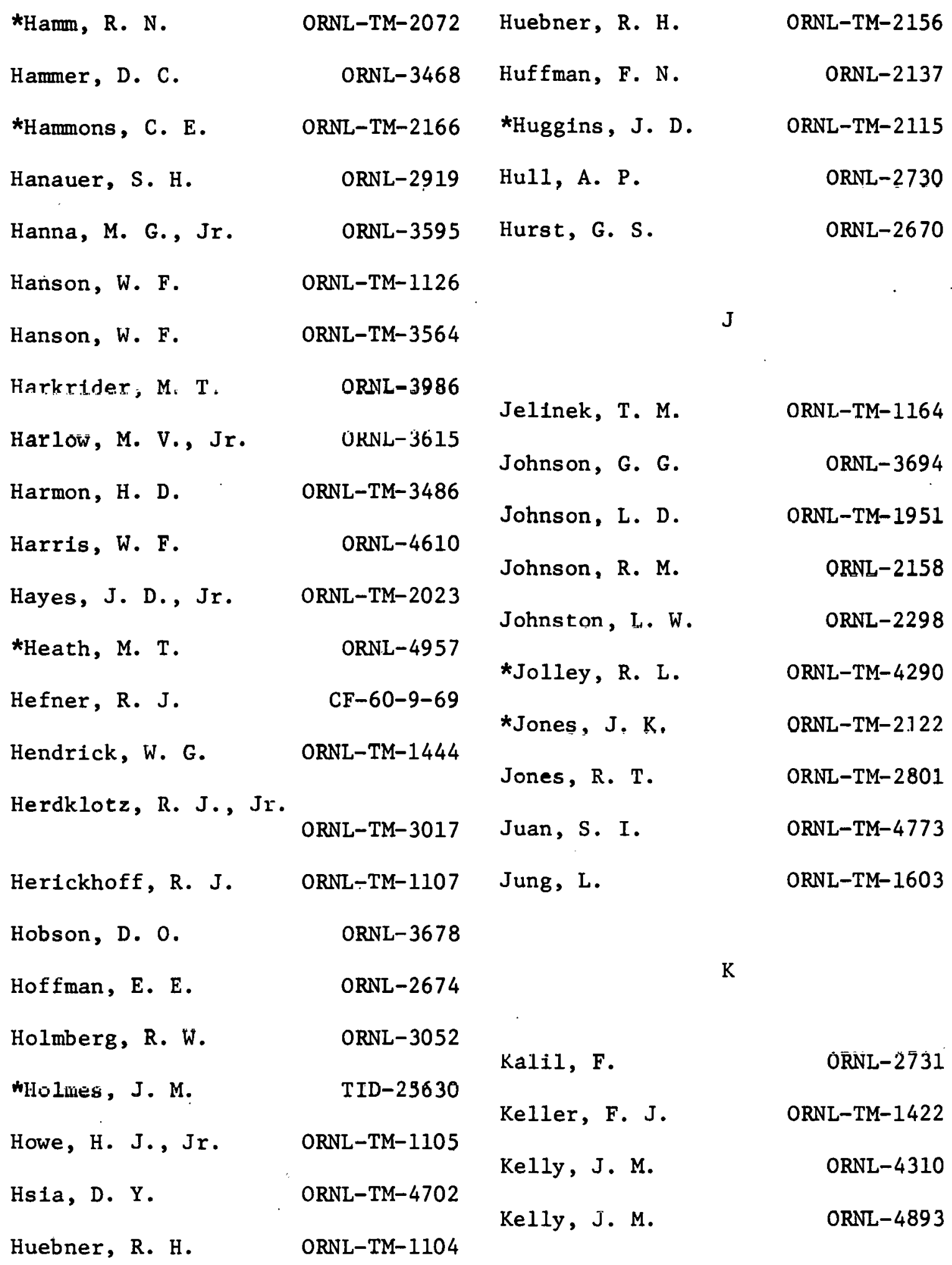

*Indicates $100 \%$ participation in the Company's Educational Assistance Program for graduate study 


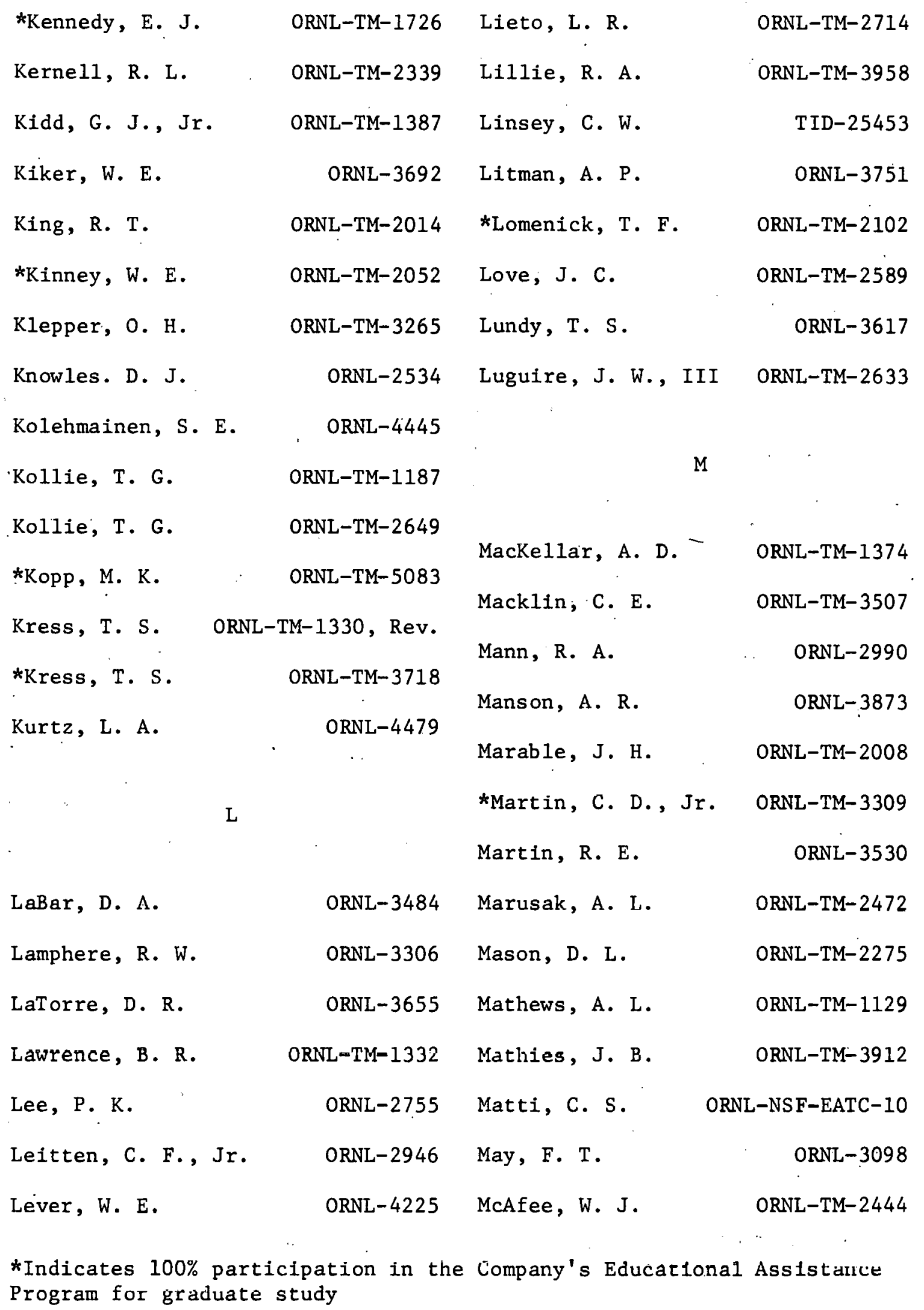




\begin{tabular}{|c|c|c|c|}
\hline McAlees, D. G. & ORNL-TM-4661 & Mruk, W. F. & ORNL-3486 \\
\hline McBrayer, J. F. & EDFB-IBP-73-8 & Muir, R. B. & ORNL-3717 \\
\hline McBrayer, J. F. & ORNL-TM-2847 & Muller, G. L. & ORNL-2669 \\
\hline McConne11, W. J. & ORNL-3463 & Murdock, J. F. & ORNL-3616 \\
\hline McCorkle, K. H. & ORNL-TM-1536 & & \\
\hline McCorkle, D. L. & ORNL-TM-3839 & N & \\
\hline Mcloy, H. E., Jr. & ORNL-3600 & & \\
\hline McGuire, G. E. & ORNL-TM-3820 & Naff, W. T. & ORNL-TM-2260 \\
\hline McKeever, J. W. & ORNL-TM-2167 & Naff, W. T. & ORNL-TM-3410 \\
\hline McNamee, R. J. & ORNL-TM-1229 & Nalley, S. J. & ORNL-TM-2030 \\
\hline McNee1y, J. R. & ORNL-TM-4697 & Nalley, S. J. & ORNL-TM-2620 \\
\hline McNeese, L. W. & ORNL-3494 & Neel, R. B. & ORNL-3172 \\
\hline Mehta, S. K. & ORNL-TM-1171 & 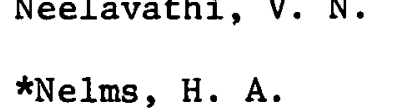 & ORNL-TM-4833 \\
\hline Mei, D. N. H. & ORNL-TM-4916 & \multicolumn{2}{|c|}{ ORNL-TM-1312, Vo1. 3} \\
\hline *Millard, J. K. & ORNL-TM-3252 & Nelson, D. B. & ORNL-TM-2025 \\
\hline *Milner, W. T. & $\mathrm{ORNL}-\mathrm{TM}=2121$ & Neleon, D. R: & ORNL-2521 \\
\hline *Mixon, W. R. & ORNL-TM-2150 & *Nelson, D. R. & ORNL-TM-2222 \\
\hline Moddeman, W. E. & ORNL-TM-3012 & *Nestor, C. W., Jr. & ORNL-TM-2556 \\
\hline Moe, H. J. & ORNL-21.36 & Niere, T.. $\mathrm{H}$, & $O R N L=T M-1333$ \\
\hline Monard, J. $\Lambda$. & ORNL-'IM-3931 & Nuslliuj, T. E. & ORNL-3473 \\
\hline *Moorc, E, E. & ORNL-4391 & & \\
\hline Morris, W. L. & ORNL-4151 & 0 & \\
\hline Morton, B. J. & ORNL-TM-1914 & Oakes, L. C. & ORNL-3685 \\
\hline
\end{tabular}

*Indicates $100 \%$ participation in the Company's Educational Assistance Program for graduate study 


\begin{tabular}{|c|c|c|c|}
\hline O'Farrel1, T. P. & ORNL-3907 & *Pitt, W. W., Jr. & ORNL-TM-2870 \\
\hline O'Kelly, L. B. & ORNL-2:887 & Poston, J. W. & ORNL-TM-3329 \\
\hline O1sen, J. N. & ORNL-TM- 3092 & Pray, H. L. & ORNL-TM-1565 \\
\hline Olson, W. D. & ORNL-2569 & Preedom, B. M. & ORNL-TM- 1860 \\
\hline Opstrup, P. A. & ORNL -4310 & Pullen, B. P. & ORNL-TM-2794 \\
\hline & , & Purcell, T. L. & ORNL -3635 \\
\hline $\mathrm{P}$ & & Purcell, T. L. & ORNL-TM-2264 \\
\hline . & & & \\
\hline Packan, N. H. & ORNL-TM-3109 & $\mathrm{R}$ & . \\
\hline Page; T. P. & ORNL-2372 & . & \\
\hline Painter, L. R. & ORNL-TM-2261 & Ragsdale, H. L. & ORNL-4318 \\
\hline Parks, J. E. & ORNL-TM-1287 & Ramsey, D. C. & ORNL-4008 \\
\hline Patterson; D. 0 & ORNL-TM-1685 & Ranie, R. P. & ORNL-4.808 \\
\hline Patterson, M. R. & ORNL-TM- 1850 & Reedy, E. K. & ORNL-TM-2214 \\
\hline Patton, W. F. & ORNL-2352 & Reinhardt, P. W. & ORNL-2969 \\
\hline Paulson, A. S. & ORNL-4144 & Richardson, C. J. & EDFB-IBP-72-13 \\
\hline Paulus, T. J. & ORNL-TM-2323 & Ricker, C. W. & ORNL-TM-1066 \\
\hline Penland, J. R. & ORNL-TM-3372 & Riedinger, M. S. & ORNL-TM-2114 \\
\hline Penny, S. K̀. & URNL-TM- 1414 & Rilts, J, J. & ORNL-TM-2991 \\
\hline Peters, R. D. & ORNL-TM-2286 & Roche, T. K. & ORNL-2524 \\
\hline Picke1, T. W. & ORNL-TM-1497 & Rochelle, J. M. & ORNL-TM-2288 \\
\hline Pigan, E. A. & ORNL-2571 & $\star_{\text {Rochelle, J. M. }}$ & ORNL-TM- 4574 \\
\hline Pigg, J. C. & ORNL-3443 & Rodriquez, . P. & ORNL-TM-1124 \\
\hline Pisanias, M. N. & ORNL-TM-3904 & Roecklein, A. K. & ORNL-3702 \\
\hline Pitt, W. W., Jr. & ORNL-TM-1683 & Roskies, R. & ORNL-3914 \\
\hline
\end{tabular}

*Indicates $100 \%$ partic1pation in the Company's Educational Assistance Program for graduate study 


\begin{tabular}{|c|c|c|c|}
\hline Rust, B. W. & ORNL-4953 & *Snider, J. W. & ORNL-TM-2320 \\
\hline Rutkowski, R. W. & ORNL-TM-3484 & Snyders, L. S. & ORNL-TM-1671 \\
\hline & & Sohrabi, M. & ORNL-TM-3605 \\
\hline $\mathrm{S}$ & & Sollins, $P$, & EDFB-IBP-72 2 \\
\hline & & Solomito, E. (M) & ORNL-TM-3530 \\
\hline Sandberg, G. R. & ORNL-TM-2660 & & \\
\hline Sanders, F. W. & ORNL-2807 & Soper, G. K. & ORNL-3696 \\
\hline *Santoro, R. T. & ORNL-4114 & Stanford, J. L. & ORNL-TM-1392 \\
\hline Satterfield, M. M. & ORNL-TM-2654 & Staum, M. M. & ORNL- 3057 \\
\hline Sayer, R. 0 . & ORNL-TM-2211 & Steffy, R. C., Jr. & ORNL-TM-2823 \\
\hline Schalbe, C. H. & ORNL-2804 & Stewart, G. W., III & ORNL -4303 \\
\hline$S \cot t, C . D$ & ORNL- 3292 & $\begin{array}{l}\text { Stiegler, J. O. } \\
\text { *stockdale, J, A. D. }\end{array}$ & $\begin{array}{l}\text { ORNL-TM-3350 } \\
\text { ORNL-TM-2546 }\end{array}$ \\
\hline Scott, C. D. & ORNL-TM-1540 & *Stoddart, W. C. T. & ORNL-TM-3248 \\
\hline$S \cot t, J . L$. & ORNL-2328 & Stone, D. R. & ORNI_-TM-2.707 \\
\hline Sergent, J. E. & ORNL-3563 & Stone, G. F. & ORNL-TM-1927 \\
\hline *Sessions, C. E. & ORNL-4561 & Stowers, B. L. & URNL-TM-3665 \\
\hline 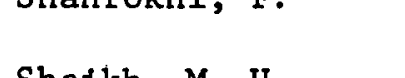 & 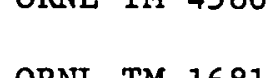 & Streetman, B. G. & ORNL-TM-1354 \\
\hline Shaikh, .. M, U. & ORNL-TM-1681 & Sutherland, J. C. & QRNL-TM- 1776 \\
\hline Sheffey, D. W. & ORNL-TM-2060 & Eweet, R. F. & ORNL- 3638 \\
\hline Sheppard, J. D. & ORNL-TM-3296 & $\mathrm{T}$ & \\
\hline Stlver, E. G. & ORNL-TM-1204 & & \\
\hline Siman-Tov, M. & ORNL-TM-2266 & Talmage, J. E., Jr. & ORNL-TM-4368 \\
\hline *Siman-Tov, M. & ORNL-TM-4626 & Tang, I-L. E. & ORNL-TM-4559 \\
\hline jims, T. M. & ORNL-3346 & Tangthieng, S. & ORNL-TM-2195 \\
\hline
\end{tabular}

*Indicates $100 \%$ participation in the Company's Educational Assistance Program for graduate study 


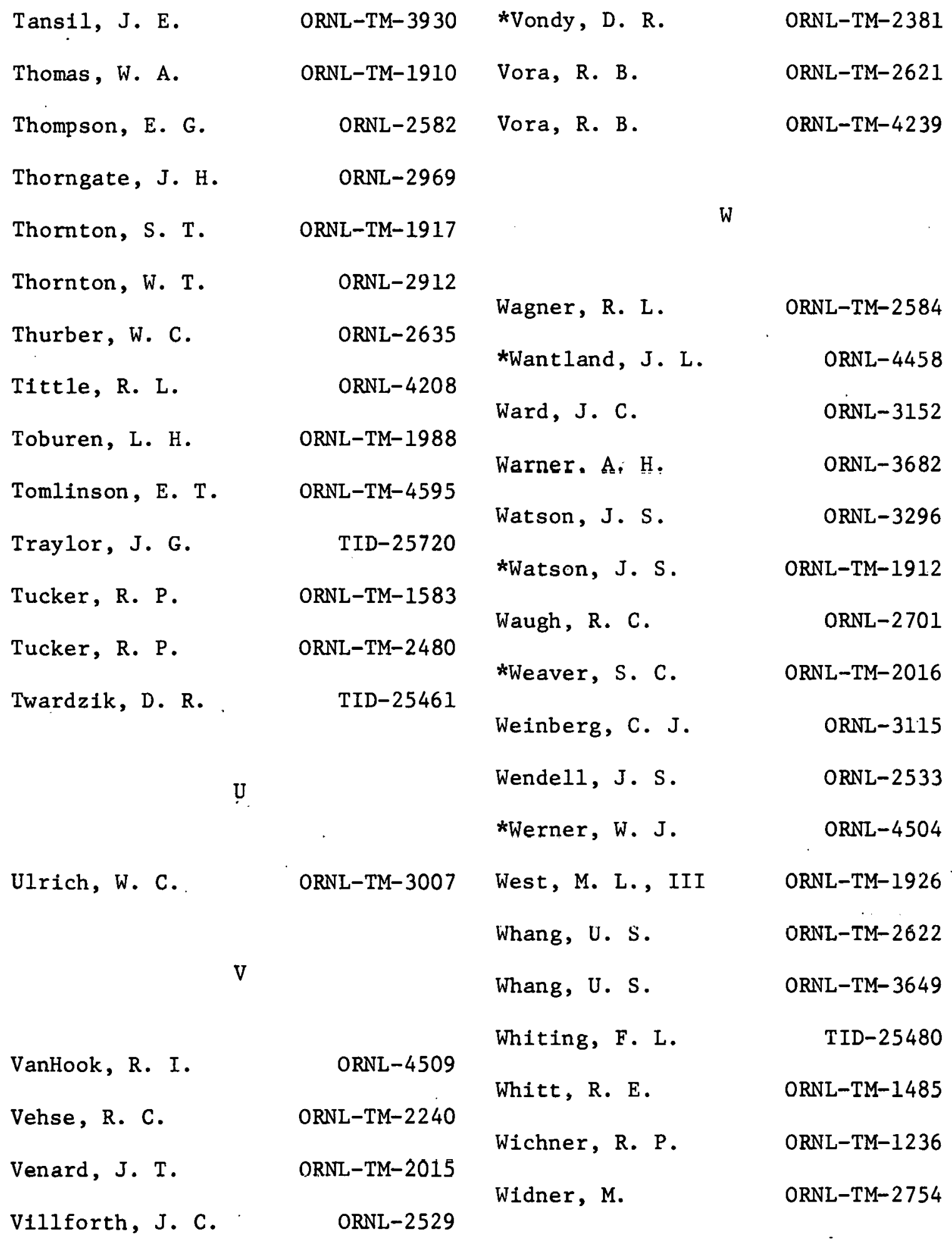

*Indicates $100 \%$ participation in the Company's Educational Assistance Program for graduate study 
Wilems, R. E.

Wilkie, W. H.

Williams, R. 0 .

Wilson, D. W.

Wilson, J. F.

Witherspoon, J. P.

*Wright, H. A.

Wright, W. C.
ORNL-TM-2101

ORNL-3469

CF-50-7-160

ORNL-TM-4597

ORNL-TM-3325

ORNL-3328

ORNL-TM-1952

ORNL-TM-1323

Yee, W. C.

ORNL-2742

Z

Zerby, C. D.

ORNL-3033

Zett1, A.

ORNL-3646

Ziegler, N. F.

ORNL-2860

Ziemer, P. L.

ORNL-2775

*Indicates $100 \%$ participation in the Company's Educational Assistance Program for graduate study 


\section{Internal Distribution}

1-2. Central Research Library

3. Document Reference Section

4. Biology Library

5. Thermonuclear Library

6. E. D. Aebischer

7. W. S. Akers

8. S. I. Auerbach

9. J. A. Auxier

10. J. A. Barker

11. C. J. Borkowski

12. F. R. Bruce

13. B. G. Catron

14. M. F. Fa1r
15. D. E. Ferguson

16-25. E. B. Howard

26. C. R. Levenhagen

27. O. L. Keller

28. F. C. Malenschein

29. G. E. Moore

30. H. Postma

31. G. D. Robbins

32. P. H. Stelson

33. J. R. Weir, Jr.

34. M. K. Wilkerson, Jr.

35-44. Laboratory Records Department

45. Laboracory Records, RC

\section{External Distribution}

46. P. L. Johnson, Oak Ridge Associated Universities, P. 0. Box 117, Oak Ridge, Tn. 37830.

47. R. L. Metter, Oak Ridge Operations Office, P. O. Boy. E, Oak Ridge, Tn. 37830

48-222. Given distribution as shown in TID-4500 under General category (25 copies - NTIS)

223. Research and Technical Support Division, ERDA, ORO 